\title{
食物の咴好と歯肉の健康に関する疫学的研究
}

九州歯科大学口腔衛生学教室 (指導: 荷宮文夫教授)
九州歯科大学口腔治療学教室 (主任 : 吉田光雄教授)

\author{
村岡俊彦 \\ (昭和45年 9 月25日受理)
}

（本論文の要旨は昭和42年10月 8 日第16回口腔衛生学会総会, 昭和42年11月 4 日第27回九州歯科学会総会, 昭和 43 年 7 月13日第17回口腔衛生学会総会, 昭和44年 5 月 24 日第29回九州荗科学会総会, および昭和44年10月12日第18 回口腔衛生学会総会に将いて発表した）

\section{ORAL PROPHYLAXISIS AND THE HEALTH OF GINGIVA WITH REFERENCE TO DIETARY HABITS}

\author{
By \\ Toshihiko MURAOKA \\ Department of Preventive Dentistry (Director: Prof. Fumio NINOMIYA) \\ Department of Operative Dentistry (Director: Prof. Mitsuo Yoshida) \\ Kyushu Dental College, Kitakyushu, Japan
}

\begin{abstract}
A survey was conducted among populations of junior and senior high school pupils residing in Kitakyushu city on several envionmental factors that would affect the oral health status of younger people. The subjects were requested to fill in the quetionaire which was designed for analysis of possible correlations between factor such as preference of foods and other dietary habits and the health of gingiva and some of oral disturbances. The questionaionaire also demanded the subjects to answer about their habit of daily tooth brushing practice to know how much they were taught to care for their own oral health. The results were summarized as follows.
\end{abstract}

\section{Health Status of Gingiva}

An unagreeable sensation of oral cavity at the time of rising in the morning was complained by 26. $6 \%$ of male subjects and $25.5 \%$ of female subjects. Bleeding from gingiva at the time of tooth brushing was experienced by $20.9 \%$ of male subjects and $22.7 \%$ of female subiects. Compacted food debris were seen in most of the subjects, but more freqently in the male. Pus formation was rarely reported. Cases of tooth mobility that were present in both senes decreased after about 14 years of age. Stippling of gigiva was seen in $28.1 \%$ of male subjects and $39.0 \%$ of female subjects. Very few cases of melanin deposition were reported. Dental calculus was reported from $17.7 \%$ of the male and $12.1 \%$ of the female.

2. Food Preference and Health of Gingiva

Incidence of periodontosis was proved to rise in those subjects who preferred foods that were cooked either soft or served hot. The same was true with those subjects who preferred cooked fishes and sweetened foods 


\section{Tooth Brushing Habit}

Once a day practice was predominant among the subjects, and so was practice of tooth brushing before breakfast.

The time spent for the practice seems to be decreased with advancing age of the subjects. Most of the subjects brushed teeth in both vertical and horizontal directions, and the lingual surface of teeth was brushed mostly in horizontal direction. A piece of tooth-brush was in use for 4 months in most of the subjects. Medium hardness of tooth brush with synthetic bristle was most frequently prefered and so was the shape of bristle with flat surface.

4. Number of Decayed Teeth and Foods Preference

About one third of the subjects had not any knowledge about how many of their teeth had suffered dental decay.

A majority of subjects had their teeth restored by fillings and other mean and the rate of such restorations inrceased slightly with increasing age of the subjects. Caries incidence was more frequent in those subjects of both sexes who preferred sweetened foods, acidic foods such as meat, fish and rice in general. The same was true in the male subjects who preferred alkaline foods such as fruit, vegetable and milk, and in the female who preferred hot foods.

\begin{tabular}{|c|c|}
\hline \multicolumn{2}{|c|}{ 目 } \\
\hline & がき \\
\hline [ & 対象 \\
\hline & 調查項目 \\
\hline & データの取扱い力法 \\
\hline & 成績ならびに考察 \\
\hline
\end{tabular}

〔I〕歯肉の健康状態に関する調查成績

A 質問形式による調查成績

1 起床時における口腔内の不快感

2 歯みがき時における出血之疼痛

3 食片压入

4 排膿

5 菌の動摇

B 質問形式による調査と歯肉の健康診查成績

1 歯肉の健康状態

2 Stippling

3 Melanin 色素沈着

4 歯石

$5 x^{2}$-検定

〔II〕食物の嘹好之歯肉の健康状態についての調査成 績

1 高温食物嗜好之䨑肉の健康状態

2 いわゆる猫舌之歯肉の健康状態

3 甘味食物嗜好之雪肉の健康状態
4 辛味食物嘹好之歯肉の健康状態

5 硬質食物嗜好之歯肉の健康状態

6 軟質食物嗜好々歯肉の健康状態

7 野菜類食物嘹好之㐘肉の健康状態

8 肉類食物搘好之歯肉の健康状態

9 魚類食物磧好之歯肉の健康状態

10 小括

$11 x^{2}$ 一検定

〔III]. 各種因子の百分比成績

1 高温食物

2 いわ功る猫舌

3 甘味食物

4 辛味食物

5 硬質食物

6 軟質食物

7 野菜類食物

8 肉類食物

9 魚類

〔IV】崡の刷掃についての調查成績

II日に抢ける菌みがさの時期

21 回の歯みがきに要する時間

3I日における歯みがきの回数

4 歯冠唇側の刷掃方法

5 歯冠舌側の刷掃方法 
61 本の歯刷子の使用期間

7 㐘刷子の刷毛硬度

8 歯刷子の刷毛の種類

9 蒌刷子の刷毛面の班態

10 茵みがき剤の種類

11 小括

〔V】食物の種類とう菌についての調査成績

1 う歯数の自覚

2 う㐘の治療

3 高温食物とう歯

4 甘味食物とう歯

5 酸性食物（米食，肉，魚，卵なよ゙）上う㐘

6 アルカリ性食物（果物，野菜，牛乳など）上 う歯

$\mathrm{V}$ むすご

引用文献

\section{ま え がき}

㐘科疾患のうち，う蝕症と霜槽膿漏症とは 2 大疾患之 いわ和，文化の進展につれて有病率は增加の傾向にあ る。

う蝕に関する疫学的研究は非常に多く，数えきれない ほどの報告がある。しかし㐘肉疾患，亡くに歯肉炎，歯 槽膿漏症についての疫学的研究は，きわぬて少ない，疾 病の発病は宿主, 病因および環境の三要素の相互作用に よるもの上されている，疾病の疫学的研究のうち，記入 式調査は環境因子の決定にきわめて重要な力法である. この調査の結果によってもっとも関係の強い因子につい て分析的疫学，さらに奏験的疫学研究によって，はじめ て疾病の予防，治療の方法が確立されるのである。記入 式調查は公菜衛生学上もっとも多く用いられ，多くの効 果をあげている。記入式調査は質問型式による場合に は, 人権, 名誉の侵害されない設問と正確な答を記入出
来るような知識と協力が必要である。毎日摄取する食物 と歯肉の健康との関係について，質問型式による記入式 調査，あわ甘て䊝肉炎，ならびに䊝槽膿漏症の口腔診査 を行ない両者の関係について研究した．対象の各年令別 に拈りる比較では，諸因子と歯肉の健否との関係をあき らかにすることはできなかった，各々の関係における年 令的変動が少なかったので，年令差を考えずに，男女 をそれぞれ，1群の対象之考えて抢こなったメ2一検定で

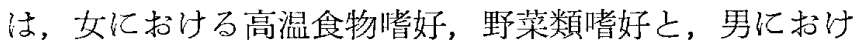
る甘味食物嗜好，軟質食物嗜好，という因子に関しては 歯肉疾患との間に関係があることが認められた。また北 九州市中・高校生の蒾の刷掃状態について調査を抗てな った．学校保健教育と保健指導上きわめて有意義な成績 を得たので研究の概要を報告する。

\section{I 対 象}

調査は2 回おこなった。第工回は昭和42年 3 月 20 日， 第 2 回は昭和43年 $5 \sim 6$ 月であった，対象の男女別，年 令別人員は表】の上扣りである. 対象の総数は，第卫回 が 2,068 人, 第 2 回が1, 364人であった。対象として選ん だのは北九州市小倉区の中学校と高等学校の生徒で, そ の年令は12〜18才である.中学・高校生を選んだ理由 は，調查項目についての自主的で正確な答が比較的得ら れやすいと考えたからである。いま一つは㐘肉疾患は成 人に多く，中高校生に少ないために，発病之関係ある因 子の分析に便利であるからである。な採学校当局の協力 を得て，担当教師より本調查の意義を説明してもらい， 生徒の正確な答が得られるように努めた。

\section{II 調查項目と診查項目}

調查項目は第1回が隶口清掃，とくに刷掃 Dental Brushing に関し，表 2 のうな項目について調べた. 第 2 回の調査は表 3 のよな調査票により食物の嗜好に 表1男女別年命別人数

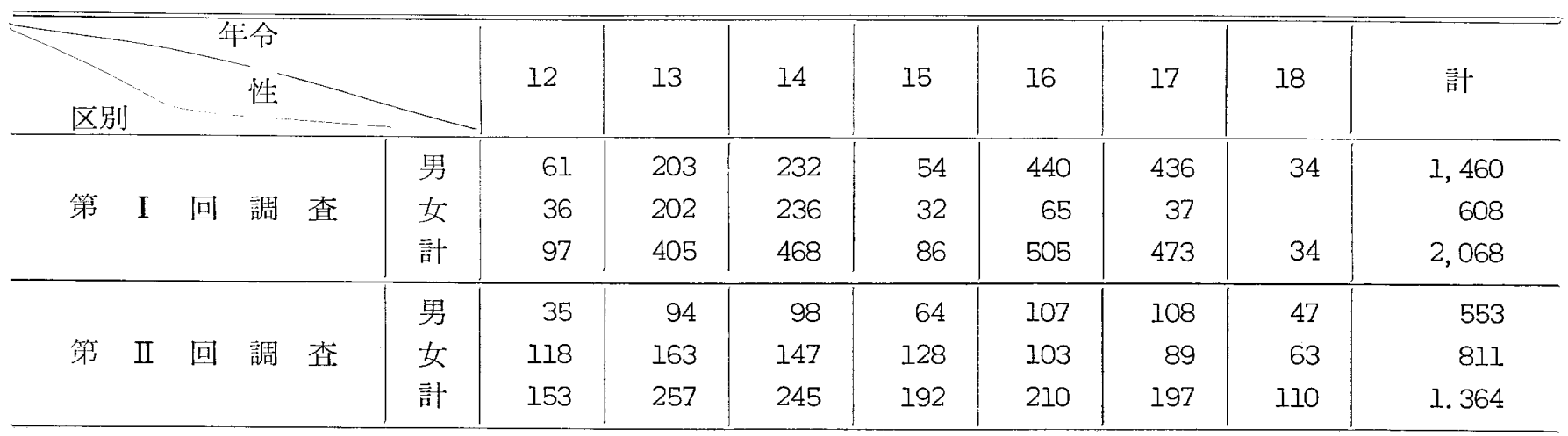


表 2

\begin{tabular}{|c|c|c|c|c|c|c|c|c|c|}
\hline No. & \multicolumn{9}{|l|}{ 学校名 } \\
\hline $\begin{array}{l}\text { 氏 } \\
\text { 名 }\end{array}$ & \begin{tabular}{l|} 
男 生年 \\
女旦
\end{tabular} & $\begin{array}{l}\text { 盟 } \\
\text { 䕎 }\end{array}$ & 年 & 月 & 日 & & & & \\
\hline 家庭联 & 学 & & 年 & & & 跑 & 年 & 月 & 日 \\
\hline
\end{tabular}

1 函ブラシを使ったり，リンゴなどを食べるときに血が出ますか（出る，出ない）

2 朝起きたとき口が粘るような不快感はありますか

3 㐘肉から膿が出る事がありますか

4 㐘が動くようになったと思いますか

5 歯と茵の間に食物がはさまると思いますか

6 食後にいつも妻揚子を使いますか

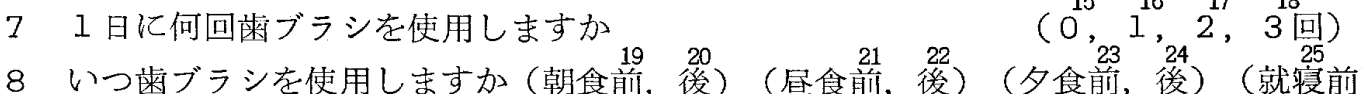

9 時々歯ブラシを使用するときは ( 1 週

101 回の歯ブラシ使用に何分かけますか（分間）

11 歯ブラシをどのように使用しますか（上下に動かす，横に動かす，その他）

12 歯の董側もみがきますか （磨く、磨かない）

13 (12)で磨く時は（上卡は動かす，横に動かす，その他）

14 使用している歯ブラシについて

(a) 毛 (ナイロン, 豚毛, 狸毛 その他)

(lb ) 毛の汃たさ (硬, 中, 軟)
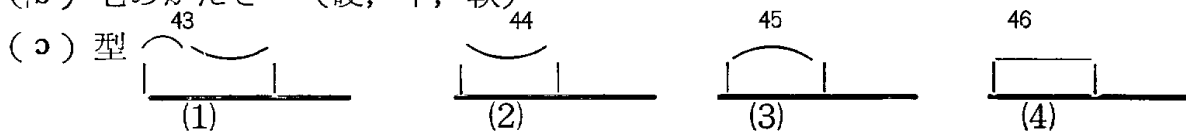

151 年間にどの位歯ブラシをとりかえますか (本 )

10 㐘磨粉について (粉, 半練, 練, 使用しない, その他)

17 雷ブラシ使用時に 出 血 (有, 無) 痛み (有, 無)

18 いつ㐘ブラシを使用するのがよいと思いますか（食前，食後）

19 工本の歯ブラシの使用期間は（５力月）

20 虫雪の治療をされたことがありますか (有， 無)

21 出歯は何本ありますか（年，知りません）

ついて抗てなっ。ささに同一対象について診査した項 目は歯肉の炎症, 盲囊, 排膿, Stippling, Melanin 色 素沈着，歯石执よ゙う歯などである、口腔の診査部位は 上下顎前歯部である。

各診査項目の判定基準はつぎのとおりとした。

Gingiva Stippling : Stipplingを認めない屯のを(一 ), 鮮明・不鮮明にかかわらずその数の少ないものを( 士)，多くて鮮明なものを（十）上した。

Melanin色素沈着：色素沈着のない6のを(一), 少 なくて淡い，多くて淡いあのを（士）, 多いか，少なく ても濃い，または多くて濃いものを(十)とした。
㐘石沈着の有無 : 菌頸部または歯肉縁部に歯石沈着の あるものを(十)，歯石沈着のないすのを(一)とし た.

歯肉の臨木的区分: 歯肉の健全なもの，歯肉炎，お よび歯槽膿漏症に区分した，歯肉炎については，歯肉の 1 部に軽い炎症があるように思われるものをあ，あきら かに歯肉炎と断定できるもの之同様に取扱い，区別しな かった。 また畨槽膿漏症についても，盲囊形成，排膿㧍 よび出血のそれぞれ，あるいはそのいくつかにより診断 される，いろいろの段階ないしは種類のものの間に一切 区別を設けず，一括して取扱った。 
〔注〕1.〜工1. までは右側の番号を○で囲んで下さい

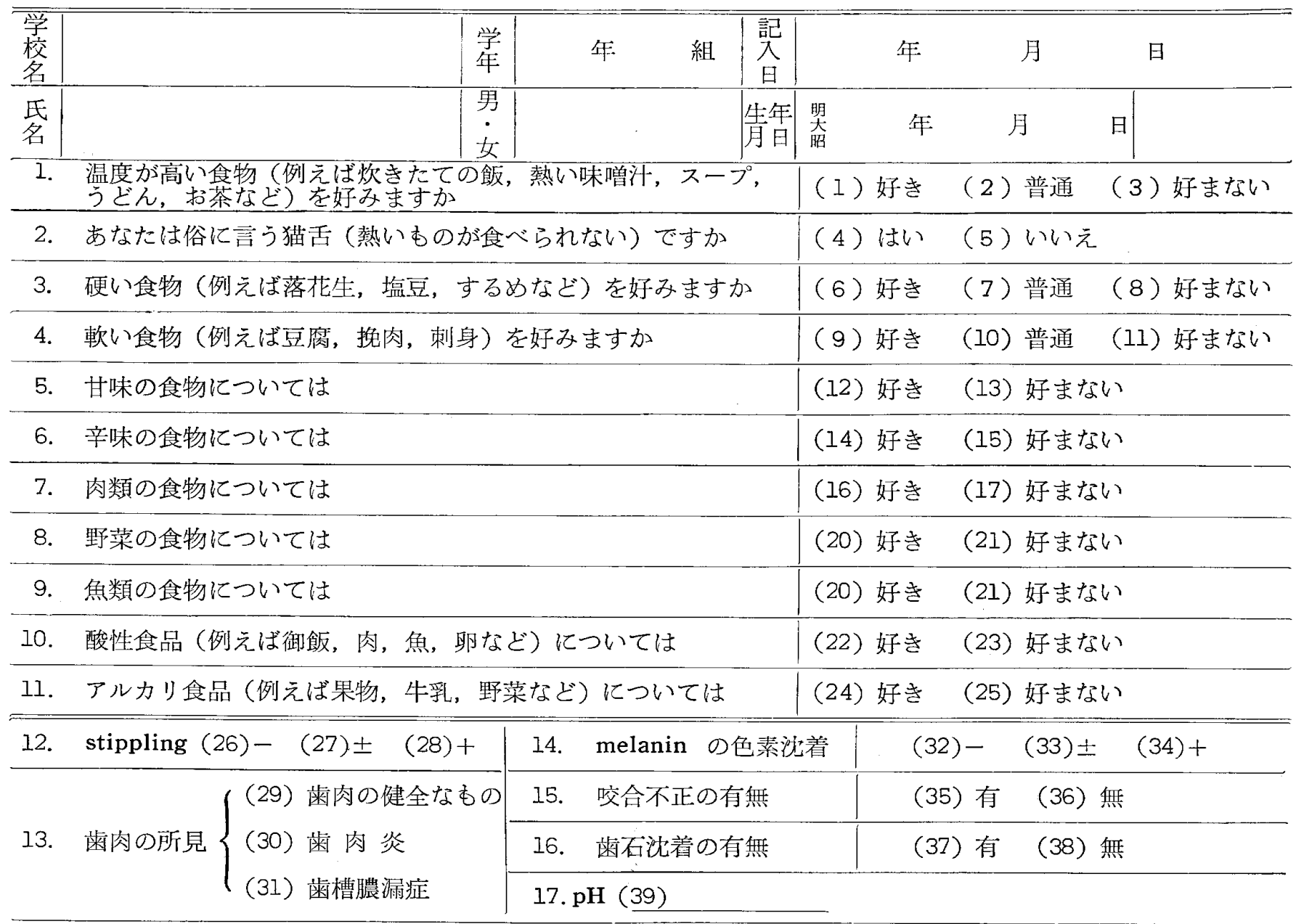

\section{III データの取扱い方法}

データは男女別，年令別に区分して算出し， 2 つの平 均値の差の比較は, 級 (年令) 別上全般的（12〜18才） との 2 様におこなった。

\section{A}

\section{B}

$\mathrm{p}_{1} \pm \mathrm{Sp}_{1}(\%) \quad \mathrm{p}_{2} \pm \mathrm{Sp}_{2}(\%)$

$\mathrm{d}(\%)$ : 2 つの平均値の差 $\mathrm{d}(\%)=\mathrm{p}_{1}-\mathrm{p}_{2}(\%)$

$\mathrm{Sd}(\%): \mathrm{d}(\%)$ 標準偏差 $\mathrm{sd}(\%)= \pm \sqrt{\mathrm{Sp}_{\mathbf{1}^{2}+\mathrm{Sp}_{2}}}(\%)$

$\mathrm{d}$ が0を中心として, $\mathrm{Sd}=\left.\left|\mathrm{Sp}^{2}{ }_{1}+\mathrm{Sp}^{2}{ }_{2}\right|\right|^{1 / 2}$ なる標準偏差 をあって正規分布するとみなせば，dがSdの1.96倍より 大きいときには， d は偶然の所産ではなく， d の生じた 理由は別にあるということができる．乙の場合 2 つ平 均値の差は危険度 $5 \%$ 以下に扔いて有意義性があるとし た.

全般的には, 各級 (年令) 每の $t o=\frac{\mathrm{d}}{\mathrm{ds}}$ の和, $\Sigma|\mathrm{to}|$ を, 比較した級の数 (k) で除し, 平均比 MR (Mean Ratio）を出した. MR が $\mathrm{S}_{\mathrm{MR}}$ の1.96 倍より大きいとき
には，2 群間の差に危険度 $5 \%$ 以下に扎いて有意義性が あるとした。

食物の嗜好ならびに歯肉部外見之歯肉の健康状態之の 関係については， $\chi^{2}$ 一検定をおこなって判定した。

\section{IV 成績ならびに考察}

〔 I 歯肉の健康状態に関する調查成績

A 質問型式に上る調查成績

1 起床時に扝ける口腔内の不快感

起床時に口腔内が权价るうな不快感があるか否かの 成績は表 4 のと㧍りである。放ばるものは男（12〜18才 ）が26.6\%，女（12〜17才）が25.5\%で，男女と屯增令 による増滅は著しくない。

2 歯みがき時に㧍ける出血之疼痛

歯みがき時やリンゴを食べる時に括ける出血は，表 5 のと抢りである．出血するあのは，男（12〜18才）が $20.9 \%$ ，女（12〜17才）が22.7\%で，男女間の差はほ上 んごない，年令が増すにつれて増減は男女とも著しくな 
表 4

起床時に打ける口空内の不快感

\begin{tabular}{|c|c|c|c|c|c|c|c|c|c|c|c|c|}
\hline \multicolumn{5}{|c|}{ 年令 } & 12 & 13 & 14 & 15 & 16 & 17 & 18 & $12 \sim 18$ \\
\hline & & 不快! & & & 61 & 203 & 232 & 54 & 440 & 436 & 34 & 1,460 \\
\hline \multirow{5}{*}{ 男 } & & & & $\mathrm{N}$ & 20 & 47 & 58 & 16 & 107 & 121 & 9 & 378 \\
\hline & b & め & る & $\%$ & 32.8 & 23.7 & 25.2 & 30.7 & 25.3 & 27.8 & 28.1 & 26.6 \\
\hline & & & & $\mathrm{N}$ & 41 & 151 & 172 & 36 & 316 & 306 & 23 & 1,045 \\
\hline & 6 & $1 \$$ & 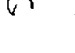 & $\%$ & 67.2 & 76.3 & 74.8 & 69.3 & 74.7 & 72.2 & 71.9 & 73. 4 \\
\hline & & 回 & 答 & $\mathrm{N}$ & & 5 & 2 & 2 & 17 & 9 & 2 & 37 \\
\hline \multirow{6}{*}{ 女 } & & & & 人数 & 36 & 202 & 236 & 32 & 65 & 37 & & 608 \\
\hline & & & & $\mathrm{N}$ & 8 & 53 & 67 & 5 & 15 & 4 & & 152 \\
\hline & 5 & め & a & $\%$ & 22.9 & 26.3 & 29.3 & 16.1 & 23.4 & 21.2 & & 25.5 \\
\hline & & & & $\mathrm{N}$ & 27 & 149 & 162 & 26 & 49 & 32 & & 445 \\
\hline & 6 & & 8 & $\%$ & 77.1 & 73.7 & 70.7 & 83.9 & 76.6 & 78.8 & & 74.5 \\
\hline & & 回 & 答 & $\mathrm{N}$ & 1 & & 7 & 1 & $I$ & 1 & & 11 \\
\hline
\end{tabular}

表 5

歯みがき時における出血

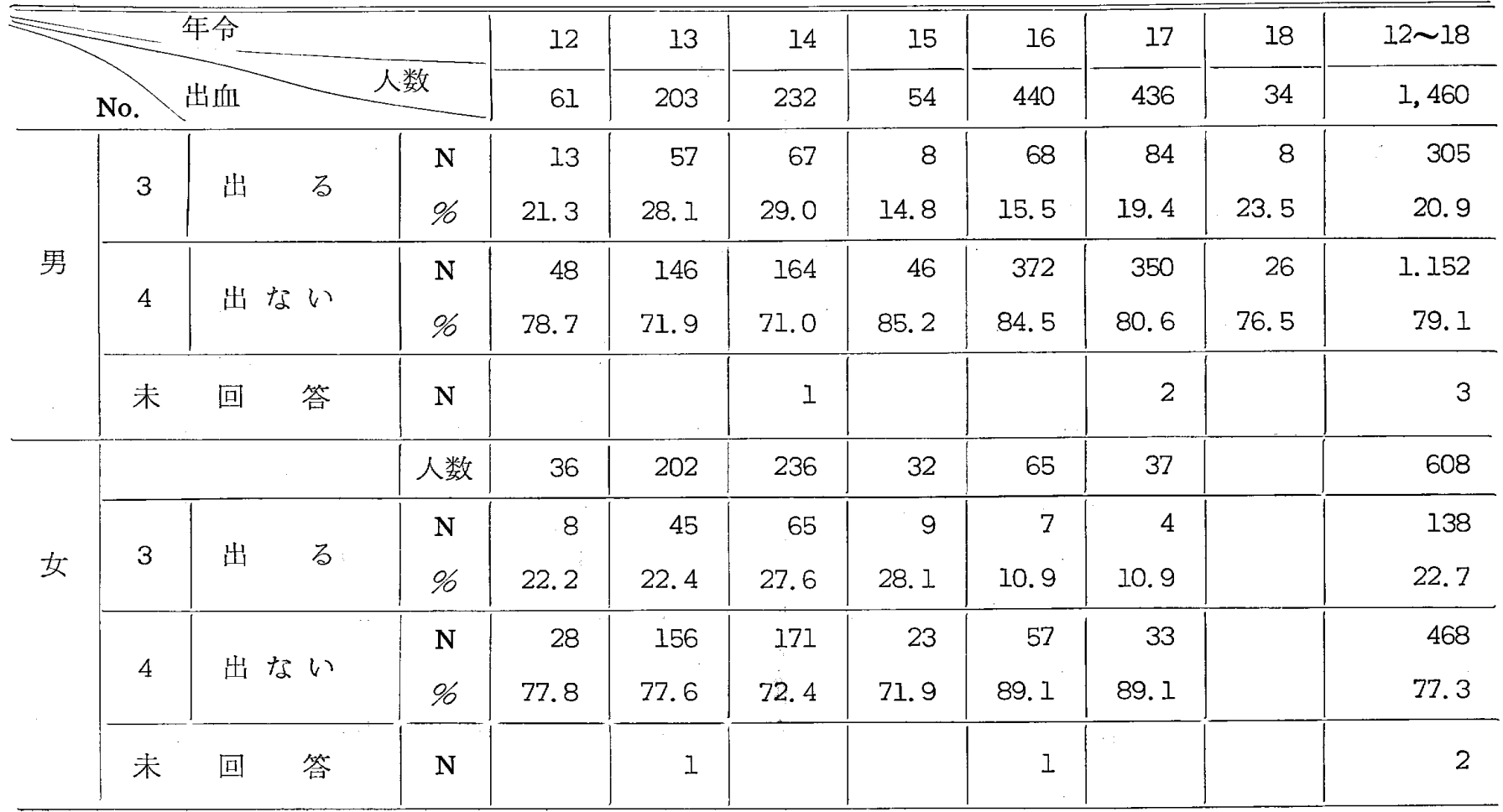


い.

松村他（1957）1） は大阪の高校女生徒 2,092 人につい て調査し, 口䐁内異常感を有するものは, 正常歯肉者に 724 人，歯肉疾患者に373人で，とくに歯肉出血との閻に は相関を認めなかったという，松井他（1959）2）は昭和 33年度京都大学新入学生 1,371 人の 口腔㟝査を招てな い, 歯肉の健康者 $79.3 \%$, 霜肉炎 $17.3 \%$, 歯槽膿漏症は 3.4\%であったと述べている。 また異常者305人について 局所のいたみ，口腔内不快感，歯肉出血などの自覚症状 の有無を調べており，自覚症状のあるすのは，㐘肉炎が 255 人中 62 人の $24.2 \%$ ，歯槽膿漏症は50人 中 32 人の 72.0 \%であったと発表している。.三宅（1963）3）注化䋐工場 工員（15５5才）の6.952人から，つぎのような分類に よる6.584人のアンケートについて発表した。 $\mathrm{N}$ 群は菌 肉組織に異常がなさそうなもの，G 群は歯肉炎があるよ うに思われるもの，P 群は料槽膿漏症の疑があるものに 分類している。增令的にP 群は增し， $\mathrm{N}$ 群ならびにG 群 は溸隇の，G群は年代的変動を示さなかった。N 群は男 が10.2\%，女が16.9\%， G 群は男が10.6\%，女が15.4 $\%$ ， G 群は男が46.1\%，女が49.2\%，P 群は男が33.1 \%，女が18.5\%である。15〜19才ではN群は男が22.1 $\%$, 女が22.4\%, G 群は男が17.5\%, 女が $18.1 \%$ ， G は男が50.2\%群，女が49.7\%，P群は男が10.2\%，女が 9.8\%であったと報告している.
歯みがき時の疼痛があるか否かは，表6のとおりであ る.いたむ子のは男（12〜18才）が6.3\%，女（12〜17 才）が10.4\%であり，男女之も增令につれてわずかに減 少の傾向を示している。

3 食片圧入

歯と歯の間に食物がはさまるか否かは，表 7 のおり である。はさまるあのは男（12〜18才）が67.2\%，女が （12〜17才）が46.6\%で，男が女よりも高率である．男 女上も增令につれて増減は著しくない。

石川他（1962）4）は歯垢の停滞，食片圧入などが，主 として雬肉付する起炎症性原因としてあげられている ことを考元机ば，食物そ机自体が歯肉炎倸対する直接的 な局所原因として大きな役割を演じていることはあきら かであると述へてて抢り，木下他（1963）5）は1,025人の 歯肉疾患を有するもののうち，その原因が食片圧入にあ ると思われるむのの割合は、全体の13.1\%であったと発 表している。

\section{4 排膿}

歯肉から膿汁が出るか否かは，表 8 のおりである。 出るあのは男（12〜18才）が2.6\%，女（12〜17才）が 4.3\%で，男女間の差は著しくなく，男女とあ增令につ れての増減はない。

松井他 (1959) 2)，三宅 (1963) 3) は歯肉組織疾患之 自覚との関係を報告し，雪槽膿漏症のうち75.8\%は自覚
表 6

\begin{tabular}{|c|c|c|c|c|c|c|c|c|c|c|c|c|}
\hline \multicolumn{5}{|c|}{ 年令 } & 12 & 13 & 14 & 15 & 16 & 17 & 18 & $12 \sim 18$ \\
\hline \multicolumn{5}{|c|}{ No. 疼痛 人数 } & 61 & 203 & 232 & 54 & 440 & 436 & 34 & 1,460 \\
\hline \multirow{5}{*}{ 男 } & 55 & \multirow{2}{*}{\multicolumn{2}{|c|}{ 有 }} & N & 13 & 20 & 23 & 3 & 19 & 9 & 2 & 89 \\
\hline & & & & $\%$ & 22.0 & 10.4 & 10.3 & 6.0 & 4.5 & 2.1 & 6.1 & 6.3 \\
\hline & \multirow{2}{*}{56} & \multirow{2}{*}{\multicolumn{2}{|c|}{ 無 }} & $\mathrm{N}$ & 46 & 172 & 200 & 47 & 401 & 418 & 31 & 1.315 \\
\hline & & & & $\%$ & 78.0 & 89.6 & 89.7 & 94.0 & 95.5 & 97.9 & 43.9 & 93.7 \\
\hline & 未 & 回 & & $\mathbf{N}$ & 2 & 11 & 9 & 4 & 20 & 9 & 1 & 56 \\
\hline \multirow{6}{*}{ 女 } & & & & 人数 & 36 & 202 & 236 & 32 & 65 & 37 & & 608 \\
\hline & \multirow{2}{*}{55} & \multirow{2}{*}{\multicolumn{2}{|c|}{ 有 }} & $\mathrm{N}$ & 6 & 19 & 31 & 4 & & 1 & & 61 \\
\hline & & & & $\%$ & 16.7 & 9.8 & 13.8 & 12.5 & & 2.7 & & 10.4 \\
\hline & \multirow{2}{*}{56} & \multirow{2}{*}{\multicolumn{2}{|c|}{ 無 }} & $\mathrm{N}$ & 30 & 175 & 194 & 28 & 61 & 36 & & 524 \\
\hline & & & & $\%$ & 83.3 & 90.2 & 86.2 & 87.5 & 100.0 & 97.3 & & 89.6 \\
\hline & 未 & 回 & 答 & $\mathrm{N}$ & & 8 & 11 & & 4 & & & 23 \\
\hline
\end{tabular}


表 7 食片压入

\begin{tabular}{|c|c|c|c|c|c|c|c|c|c|c|c|}
\hline \multirow{2}{*}{\multicolumn{4}{|c|}{ No. 年令 }} & 12 & 13 & 14 & 15 & 16 & 17 & 18 & $12 \sim 18$ \\
\hline & & & & 61 & 203 & 232 & 54 & 440 & 436 & 34 & 1,460 \\
\hline \multirow{5}{*}{ 男 } & \multirow{2}{*}{11} & \multirow{2}{*}{ はさまる } & $\mathrm{N}$ & 44 & 136 & 165 & 25 & 266 & 306 & 22 & 964 \\
\hline & & & $\%$ & 72.1 & 66.9 & 71.7 & 49.0 & 62.5 & 71.4 & 64.7 & 67.2 \\
\hline & \multirow{2}{*}{12} & \multirow{2}{*}{ はさまらない } & $\mathrm{N}$ & 17 & 67 & 65 & 26 & 159 & 123 & 12 & 469 \\
\hline & & & $\%$ & 27.9 & 33.1 & 28.3 & 51.0 & 37.5 & 28.6 & 35.3 & 32.8 \\
\hline & 末 & 回答 & $\mathrm{N}$ & & & 2 & 3 & 15 & 7 & & 27 \\
\hline \multirow{6}{*}{ 女 } & & & 人数 & 36 & 202 & 236 & 32 & 65 & 37 & & 608 \\
\hline & \multirow{2}{*}{11} & \multirow{2}{*}{ はさまる } & $\mathrm{N}$ & 20 & 127 & 63 & 23 & 32 & 25 & & 290 \\
\hline & & & $\%$ & 57.1 & 64.4 & 27.0 & 67.6 & 50.0 & 71.4 & & 48.6 \\
\hline & \multirow{2}{*}{12} & \multirow{2}{*}{ はさまらない } & $\mathrm{N}$ & 15 & 70 & 171 & 9 & 32 & 10 & & 307 \\
\hline & & & $\%$ & 42.9 & 35.6 & 73.0 & 32.4 & 50.0 & 28.6 & & 51.4 \\
\hline & 未 & 回 & $\mathrm{N}$ & 1 & 5 & 2 & & 1 & 2 & & 11 \\
\hline
\end{tabular}

表 8

排

膿

\begin{tabular}{|c|c|c|c|c|c|c|c|c|c|c|c|c|}
\hline \multirow{2}{*}{\multicolumn{5}{|c|}{ No. 膿 }} & 12 & 13 & 14 & 15 & 16 & 17 & 18 & $12 \sim 18$ \\
\hline & & & & & 61 & 203 & 232 & 54 & 440 & 436 & 34 & 1,460 \\
\hline \multirow{5}{*}{ 男 } & \multirow{2}{*}{7} & \multirow{2}{*}{ 出 } & \multirow{2}{*}{ る } & $\mathrm{N}$ & 3 & 6 & 9 & 2 & 7 & 9 & 2 & 38 \\
\hline & & & & $\%$ & 5.0 & 3.0 & 3.9 & 3.8 & 1.6 & 2.1 & 5.9 & 2.6 \\
\hline & \multirow{2}{*}{8} & \multirow{2}{*}{\multicolumn{2}{|c|}{ 出ない }} & $\mathrm{N}$ & 58 & 191 & 219 & 51 & 431 & 425 & 32 & 1,407 \\
\hline & & & & $\%$ & 95.0 & 97.0 & 96.1 & 96.2 & 98.4 & 97.9 & 94.1 & 97.4 \\
\hline & 未 & 回答 & & $\mathrm{N}$ & & 6 & 4 & 1 & 2 & 2 & & 15 \\
\hline \multirow{6}{*}{ 女 } & & & & 人数 & 36 & 202 & 236 & 32 & 65 & 37 & & 608 \\
\hline & \multirow{2}{*}{7} & & \multirow{2}{*}{ る } & $\mathrm{N}$ & 2 & 5 & 12 & 4 & 1 & 2 & & 26 \\
\hline & & & & $\%$ & 5.6 & 3.1 & 5.2 & 12.5 & 1.6 & 5.5 & & 4.3 \\
\hline & \multirow{2}{*}{8} & \multirow{2}{*}{ 出な } & \multirow{2}{*}{$w$} & $\mathrm{~N}$ & 34 & 193 & 222 & 28 & 63 & 35 & & 575 \\
\hline & & & & $\%$ & 94.4 & 96.9 & 94.8 & 87.5 & 98.4 & 94.5 & & 95.7 \\
\hline & 未 & 回 & 答 & $\mathrm{N}$ & & 4 & 2 & & 1 & & & 7 \\
\hline
\end{tabular}




\begin{tabular}{|c|c|c|c|c|c|c|c|c|c|c|c|}
\hline \multicolumn{4}{|c|}{ 表 9} & 歯 & の & 動 & 摇 & & & & \\
\hline \multicolumn{4}{|c|}{$\bar{N}$ 年令 } & 12 & 13 & 14 & 15 & 16 & 17 & 18 & $12 \sim 18$ \\
\hline \multicolumn{4}{|c|}{ No. 動 } & 61 & 203 & 232 & 54 & 440 & 436 & 34 & 1,460 \\
\hline \multirow{5}{*}{ 男 } & \multirow{2}{*}{9} & & $\mathrm{~N}$ & 15 & 42 & 42 & 10 & 50 & 66 & 6 & 231 \\
\hline & & (3) & $\%$ & 24.6 & 21.0 & 18.7 & 19.2 & 11.6 & 15.3 & 17.6 & 16.2 \\
\hline & \multirow{2}{*}{10} & \multirow{2}{*}{ 思わない } & $\mathrm{N}$ & 46 & 158 & 182 & 42 & 380 & 364 & 28 & 1,200 \\
\hline & & & $\%$ & 75.4 & 79.0 & 81.3 & 80.8 & 88.4 & 84.7 & 82.4 & 83.8 \\
\hline & 未 & 回＼cjkstart答 & $\mathrm{N}$ & & 3 & 8 & 2 & 10 & 6 & & 29 \\
\hline \multirow{3}{*}{$\because$} & & & 人数 & 36 & 202 & 236 & 32 & 65 & 37 & & 608 \\
\hline & & & $\mathrm{N}$ & 6 & 45 & 54 & 4 & 6 & 2 & & 117 \\
\hline & $y$ & & $\%$ & 16. 7 & 23.0 & 23.7 & 12.1 & 9.5 & 5.8 & & 19.8 \\
\hline \multirow[t]{3}{*}{ 女 } & I & \multirow{2}{*}{ 思わない } & $\mathrm{N}$ & 30 & 151 & 174 & 27 & 57 & 33 & & 472 \\
\hline & 10 & & $\%$ & 83.3 & 77.0 & 76.3 & 87.9 & 90.5 & 94.2 & & 80.2 \\
\hline & 未 & 回 答 & $\mathrm{N}$ & & 6 & 8 & 1. & 2 & 2 & & 19 \\
\hline
\end{tabular}

症状をもたないものがあり，定期診断により早期発見が 望ましいと報告している。

\section{5 崡の動摇}

㐘が動くようになったか否かは，表 9 のお方りであ る.歯が動くようになったのは，男 (12〜18才) が16.2 $\%$, 女 (12〜17才) が19.8\%で, 男女間の差はない. 男 女之もに12〜14才に㨟いて高率でその後増令につれて減 少している、12〜14才に扔いてはまだ乳歯の残存があ り，とのととが12〜14才に拈りる歯の動摇率が高い原因 となっているのではあるまいか.12〜18才では男女と屯 歯の骨植状態を弱める上うな疾患，たとえば歯槽膿漏症 などはほとんど考えられない。

今川 (1956）6）は正常の歯の動摇度は，年令により差 があり，7〜8才で相当に大きく，9才でもまだかなり 大きく, 10〜15才の間で除々に小さくなり，16〜17才で 急にきわめて小さくなり，18〜25才でもきわめて小さい という。 木下他 (1963) 5) は歯肉疾患の原因と臨床所見 とに関し報告している。すなわ診療録から歯肉疾患の 原因的要素を分類して，局所的要素上全身的要素に大別 し，さらに局所的要素は発炎性之機能的原因に分けてい る. 発炎性原因を歯垢, 雬石, 食片圧入, Over hangの充填 物，補経物，不適当な歯刷子使用，口呼吸，および他の 原因の 7 項目に機能的原因之外傷性咬合, 不適合義歯,
不働歯，開咬，不正咬合，異常習慣などの6 項目に分類 している，全身的原因は，老化，栄養障害，妊娠，糖代 謝障害, アレルギー性体質, 抢よびいびきと崡肉疾患之 の関係, 歯の動摇之歯槽骨の吸収状態との関係などの調 查を抢こなっている。，その結果, 原因について, 歯垢, 粜石，食片圧入，不適合な充填物，補綴物などの発炎性 局所的原因が全体の $61.7 \%$ ，外傷性咬合などの機能的原 因が全体の30.9\%，乙れらを合わせた局所的原因が全体 の2.6\%で，残り7.4\%が全身的要素であった．全身的 要素のうち, 老化がもっとも多く, ついで栄養障害であ る。病型は炎症型, 泥合型, 負担過重型の順に少ない. 歯䡉り之歯肉疾患々の関係は不明といい，いびき，口呼 吸は症状を悪化させるようであると報告している，歯肉 疾患の患者の初彰時の口腔清掃はがいして不良, 歯の動 摇之雪槽骨の吸収度, 吸収型との関係は歯槽骨の吸収程 度が高くなると，動摇は増し，垂直型と混合型では水平 型より屯動摇の程度が強い．動摇がなくても吸収してい るものは全体の56\%，動摇は全体の44\%であったよいっ ている，岩井（1969）7）は女子短大生の歯槽膿漏症でな いむのを選び，歯磨剤による歯肉疾患予防の臨床的実験 を㧍こない，自覚症状として歯の動摇の停止を比較して いる. 口腔衛生学会菌牙周囲組織垁患調查委員会 (1969 ）8）はわが国における歯牙周囲組織疾患比関する調查報 
告を発表し，10才以上955人を対象之し，歯の動摇は6. 2 \%で増令的に増加するととを報告している．

B 質問型式による調査と歯肉の健康診查成績 荬肉の健康診査と質問型式による Stippling, Mela- nin 抢よび歯石について調查し，両者の関 係を研究し t.

I霜肉の健康状態

男女別，年令別に歯肉の健康なむの，歯肉炎扣よび歯 表10 男女年令別㐘肉健康者，歯肉炎执よび歯槽膿漏症出現率（％）

\begin{tabular}{|c|c|c|c|c|c|c|c|c|c|c|c|c|}
\hline \multirow{2}{*}{\multicolumn{2}{|c|}{ 年令 }} & \multirow{3}{*}{$\frac{N}{35}$} & \multirow{2}{*}{$\frac{\text { 歯 }}{\mathrm{K}}$} & \multirow{2}{*}{ 健 } & \multirow{2}{*}{$\begin{array}{l}\text { 康 者 } \\
\pm \mathrm{Sp} \\
\end{array}$} & \multirow{2}{*}{$\begin{array}{l}\text { 歯 } \\
\mathbf{K} \\
\end{array}$} & \multirow{2}{*}{ 肉 } & \multirow{2}{*}{$\frac{\text { 炎 }}{ \pm S p}$} & \multirow{2}{*}{$\frac{\text { 篓 }}{K}$} & \multirow{2}{*}{\multicolumn{2}{|c|}{$\begin{array}{c}\text { 槽 膿 漏 } \\
\mathrm{p} \quad \pm \mathrm{Sp}\end{array}$}} & \multirow{3}{*}{$\frac{\frac{\text { 告肉非健康者 }}{\mathrm{p}}}{20.0}$} \\
\hline & & & & & & & & & & & & \\
\hline \multirow{8}{*}{ 男 } & 12 & & 28 & 80.0 & 6.76 & 7 & 20.0 & 6.76 & 0 & & & \\
\hline & 13 & 94 & 77 & 81.8 & 3.98 & 16 & 17.1 & 3.88 & 1 & 1.1 & 1.08 & 18.2 \\
\hline & 14 & 98 & 64 & 65.3 & 4.81 & 32 & 32.7 & 4.74 & 2 & 2.0 & 1.41 & 34.7 \\
\hline & 15 & 64 & 44 & 68.7 & 5.80 & 18 & 28.2 & 5.62 & 2 & 3.1 & 2.16 & 31.3 \\
\hline & 16 & 107 & 81 & 75. 7 & 4. 15 & 23 & 21.5 & 3.97 & 3 & 2.8 & 1.59 & 24.3 \\
\hline & 17 & 108 & 83 & 76.8 & 4.06 & 21 & 19.5 & 3.81 & 4 & 3.7 & 1.82 & 23.2 \\
\hline & 18 & 47 & 42 & 89.4 & 4. 49 & 5 & 10.6 & 4.49 & 0 & & & 10.6 \\
\hline & 計 & 553 & 419 & 75.8 & 1.82 & 122 & 22.1 & 1.76 & 12 & 2.1 & 0.61 & 24.2 \\
\hline \multirow{8}{*}{ 女 } & 12 & 118 & 91 & 77.1 & 3.87 & 26 & 22.I & 3.82 & 1 & 0.8 & 0.82 & 22.9 \\
\hline & 13 & 163 & 117 & 71.7 & 3.53 & 42 & 25.9 & 3.42 & 4 & 2.4 & I. 20 & 28.3 \\
\hline & 14 & 147 & 104 & 71.8 & 3.71 & 39 & 26.5 & 3.64 & 4 & 2.7 & I. 34 & 28.2 \\
\hline & 15 & 128 & 103 & 80.4 & 3.51 & 22 & 17.3 & 3.34 & 3 & 2.3 & 1.32 & 19.6 \\
\hline & 16 & 103 & 67 & 66.0 & 4.67 & 30 & 28.1 & 4.43 & 6 & 5.9 & 2.32 & 34.0 \\
\hline & 17 & 89 & 61 & 68.6 & 4.92 & 21 & 23.5 & 4.49 & 7 & 7.9 & 2.86 & 31.4 \\
\hline & 18 & 63 & 47 & 74.7 & 5.48 & 15 & 23.7 & 5.36 & $I$ & 1.6 & I. 58 & 25.3 \\
\hline & 計 & 811 & 590 & 72.8 & 1.56 & 195 & 24.0 & 1.56 & 26 & 3.2 & 0.62 & 27.2 \\
\hline
\end{tabular}

槽膿漏症の出現率（\%）は表10のとおりである。柬肉の 健沗なものは，男が65〜89\%，女が66〜80\%である。 12 〜18才の全資料では男が553人中419人の 75. 8\% ，女が 811 人中 560 人の $72.8 \%$ である。歯肉炎と歯槽膿漏症では 男がll〜35\%，女が20〜34\%で男女間の差はほとんどな く, 男女とも年令的増減は著しくない。性別総人員中歯 肉炎は，男 553 人中 122 人の $22,1 \%$ ，女 811 人中 195 人の $24.0 \%$ である。歯槽膿漏症は男 12 人の $2,1 \%$, 女 26 人の 3.2\%である．松村他（1957）1）は2,092人中歯肉炎疾患 者に373人の15\%であると発表している，松井他（1959 ）2）は歯肉の健康者 $79.3 \%$ ，歯肉災 $17.3 \%$, 歯槽膿漏症 は3. $4 \%$ であったと述べている.

\section{Stippling}

蒾肉の健康状態と Stippling の (一), (土), $(+)$ と の関係は表11のとおりである。男女と屯歯肉の健康なも のでは Stippling の (十) と（士）のあのが(一)のも のよりも多く，逆に歯肉炎炎歯槽膿漏症をむつものでは わずかに少ない，南他（1959）9）は，㽷肉炎から歯槽膿 漏症へ上進むにつれて Stippling の保有率は低くなり，
増令につれて手保有率はだんだん低下するといってい る。また歯肉の趾全なもののうち, Stippling を保有す るものは24.1\%であり，同じく増令につれて漸減すると 述べている．松井他（1959）2）は実験的に成犬の歯肉 に温熱的刺激を与えた場合, 歯肉疾患の進行につれて Stipplingは漸減するといって扔り，三宅（1963）3）は 崡肉の健全なものでは62.3〜64.7\%, 歯肉炎のものでは 48.9 60.5\%, 蒌槽膿漏症のものでは44.0〜 59.4\%の率 で Stippling が存在すると述べている．原（1963）10は 雪槽膿漏症の病因に関し，10５9才の男女 2,597名の Stippling の存在について調查し, 健康柬肉に招ける存 在頻度は各年令を通じて高いが，雪間乳頭部および遊離 部では，年令が増すにつれてその頻度を減じ，固着部で は一定の傾向を示さず，年令とは無関係に比較的大きな 頻度のバラッキを示すのに対し，歯周組織疾患が存在す る場合は健康歯肉にくらべて，その頻度が非常に低いと 発表している。著者の調査では Stippling があるものは 男が28.1\%，女が39.0\%でわずかに女に多い． 
St i p p l i n g

\begin{tabular}{|c|c|c|c|c|c|c|c|c|c|c|c|c|c|c|c|c|c|c|c|c|}
\hline & \multicolumn{2}{|c|}{ 歯肉の所見 } & \multicolumn{2}{|c|}{ Stippling } & \multicolumn{2}{|c|}{12 才 } & \multicolumn{2}{|c|}{13 才 } & \multicolumn{2}{|l|}{14} & \multicolumn{2}{|l|}{15} & \multicolumn{2}{|l|}{16} & \multicolumn{2}{|l|}{17} & \multicolumn{2}{|c|}{18 才 } & \multicolumn{2}{|c|}{ 計 } \\
\hline & No. & 区別 & $\mathrm{N}$ & 別 & $\mathrm{N}$ & $\%$ & $\mathrm{~N}$ & $\%$ & $\mathrm{~N}$ & $\%$ & $\mathrm{~N}$ & $\%$ & $\mathbf{N}$ & $\%$ & $\mathrm{~N}$ & $\%$ & $\mathrm{~N}$ & $\%$ & $\mathbf{N}$ & 96 \\
\hline & \multirow{3}{*}{2} & \multirow{3}{*}{ 康 } & & - & \multirow{3}{*}{\multicolumn{2}{|c|}{\begin{tabular}{r|r|}
13 & 37.1 \\
10 & 28.6 \\
5 & 14.3
\end{tabular}}} & 22 & 23.4 & 8 & 8.2 & 6 & 9.4 & 14 & 15.9 & 10 & 9.3 & 5 & 10.6 & & 14.7 \\
\hline & & & 27 & \pm & & & 40 & 42.5 & 14 & 14.3 & 15 & 23.4 & 52 & 48.6 & 36 & 33.6 & 20 & 42.6 & 187 & 38.8 \\
\hline & & & 2 & + & & & 15 & 15.9 & 42 & 42.8 & 23 & 35.9 & 12 & 11.2 & 37 & 34.2 & 17 & 36.2 & 151 & 27.3 \\
\hline & & \multirow{3}{*}{ O 菌肉炎 } & & - & \multirow{3}{*}{\multicolumn{2}{|c|}{\begin{tabular}{r|r}
5 & 14.3 \\
2 & 5.7 \\
0 & 0
\end{tabular}}} & \multicolumn{2}{|r|}{212.9} & 23 & 23.6 & 13 & 20.4 & 18 & 16.8 & 13 & 12.0 & 2 & 4. 2 & \multicolumn{2}{|c|}{8615.6} \\
\hline & 30 & & 2 & \pm & & & 2 & 44.2 & 8 & 8. 1 & 4 & 6.2 & 5 & 4.7 & 8 & 7.5 & 3 & 6.4 & 34 & 6.1 \\
\hline & & & & + & & & c & 0 & 1 & 1.0 & 1 & 1.6 & 0 & 0 & 0 & 0 & 0 & 0 & 2 & 0.4 \\
\hline & \multirow{3}{*}{31} & \multirow{3}{*}{ 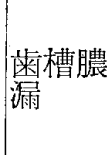 } & & - & c & o & ] & 1.1 & 2 & 2.0 & 2 & 3. 1 & 3 & 2.8 & 3 & 2.8 & 0 & 0 & 11 & 2.0 \\
\hline & & & 2 & \pm & c & ol & $c$ & 0 & 0 & 0 & 0 & 0 & 0 & 0 & 1 & 0.9 & 0 & 0 & 1 & 0.1 \\
\hline & & & 2 & + & & 0 & $c$ & 0 & 0 & 0 & 0 & 0 & 0 & 0 & 0 & 0 & 0 & 0 & 0 & 0 \\
\hline & \multirow{3}{*}{2} & \multirow{3}{*}{ 康 } & & - & \multirow{3}{*}{\multicolumn{2}{|c|}{$\begin{array}{l}1411.9 \\
4336.4 \\
3428.8\end{array}$}} & 13 & $\begin{array}{l}3.9 \\
3\end{array}$ & 11 & 7.5 & 8 & 6.2 & 6 & 5.8 & 3 & 3.4 & 0 & 0 & 55 & 6.8 \\
\hline & & & 27 & 上 & & & 52 & 231.9 & 52 & 35.4 & 39 & 30.5 & 18 & 17.5 & 24 & 26.9 & 7 & 11.1 & & 29.0 \\
\hline & & & 2 & + & & & 52 & 231.9 & 41 & 27.9 & 56 & 43.7 & 43 & 41.7 & 34 & 38.3 & 40 & 74.6 & & 37.0 \\
\hline & & \multirow{3}{*}{ 歯肉炎 } & & - & \multirow{3}{*}{\multicolumn{2}{|c|}{\begin{tabular}{r|r|}
12 & 10.3 \\
9 & 7.6 \\
5 & 4.2
\end{tabular}}} & 2 & 414.8 & 19 & 12.9 & 12 & 5 & 22 & 21.3 & 10 & 11.2 & 10 & 15.8 & 109 & 13.4 \\
\hline & \multirow[t]{2}{*}{30} & & 2 & \pm & & & 13 & 37.9 & 18 & 12.2 & 8 & 6.2 & 7 & 6.9 & 10 & 11.2 & 5 & 7.9 & 70 & 8.6 \\
\hline & & & & + & & & & 53.2 & 2 & 1.4 & 2 & 1.6 & 1 & 0.9 & I) & 1.1 & 0 & 0 & 16 & 2.0 \\
\hline & & & & - & & 0.8 & 3 & \begin{tabular}{l|l}
3 & 1.8
\end{tabular} & & 2.7 & 3 & 2.3 & 6 & 5.9 & 7 & 7.9 & 1 & 1.6 & 25 & 3.I \\
\hline & 31 & 膿 & & \pm & & & & 10.6 & 0 & 0 & 0 & 0 & 0 & 0 & 0 & 4 & 0 & 0 & 1 & 0.1 \\
\hline & & & 28 & + & & & 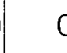 & 0 & 0 & 0 & 0 & 1 & 0 & 0 & 0 & o & 0 & 0 & 0 & 0 \\
\hline
\end{tabular}

\section{Melanin色素沈着}

歯肉の健康状態上 Melanin 色素沈着の ( （十）之の関係は，表12の上扔りである，男女之も菌肉 の健康者, 霖肉炎, 抢よび歯槽膿漏症をむつもののいず れも, Melanin 色素沈着の (一)と（士）の差は著し くない.

安藤（1959）11)色素沈着者は男が20\%，女が16\%で 前菌が多く, 増令的変化はないといい, 南他 (1959）6) は男女己もに歯肉炎ならびに歯槽膿漏症をむつものに色 素沈着を認め, 長谷川 $(1955 ， 1960)$ 12,13) は某金属鉱山 抗内従業員の雷肉Melanin色素沈着が27.0\%であったと いう．松村他（1962）14)は歯肉色素沈着の発現率は農村 群が65.8\%，都市群が46.4\%であったと発表した。三宅 (1963) 3) は蒾肉 Melanin 色素沈着は, 歯肉の健康な もので6.6〜3.7\%，雨肉炎老むつもので 10.5 4.1\%, 歯槽膿漏症をむつあので14.2〜3.4\%であり，女よりも 男に多い之報告している。著者の調查では男が 0.9\%， 女が2.7\%で男女とあきわめて少ない。

\section{4 荘石}

雬肉の健康状態之歯石の有無との関係は，表13のとお
りである，男女とも歯肉の健康者之㐘肉炎をあつもの は，歯石のあるものよりもない者化多い。

南他（1956）15)によると，7〜12才までの学生の歯石 は，㐘周組織疾患にかかってから沈着するものが多く， 歯石が沈着して屯歯肉炎になるとは限らないということ であり，森本他（1962）16) は事業所従業員の歯石沈着は 男が30.7\%，女が34.2\%であったと発表した．徳植他 （1955）17)は妊産婦の崡石沈着が 9 40\%であったとい い, 河合 (1956) 18)は某鉱山の抗外之抗内の従業員の歯 肉炎は，抗内 $38.7 \%$ ，抗外は36.8\%，歯槽膿漏症は抗内 $36.7 \%$, 抗外は $19.0 \%$ で歯肉炎, 歯槽膿漏症と屯歯石沈 着量の多いむのほど発病が多い之報告した。瀬戸（1957 ）19)は歯石が沈着している手のは，一般に増令につれて 増し, 都市以外の調査に扔いて山村, 農魚村の順に低い という。村上（1959）20)は某刑務所受刑者20～79才の 1,323名中歯石沈着は75\%6であっといい，和泉（1960 ）21)は鉱山従業員の環境之歯石沈着状態，ならびに歯肉 炎, 歯槽膿漏症の発生状態について発表し, 勤務年数に 比例して増加するといっている. 安藤 (1958) 22)は， 6 〜15才の歯牙沈着物について統計学的観察を抢こない， 
表12

Melanin 色 素沈着

\begin{tabular}{|c|c|c|c|c|c|c|c|c|c|c|c|c|c|c|c|c|c|c|c|c|}
\hline & \multicolumn{2}{|c|}{ |歯肉 の所見 } & \multicolumn{2}{|c|}{ 絫ラニン色 } & \multicolumn{2}{|c|}{$12 才$} & \multicolumn{2}{|c|}{13 才 } & \multicolumn{2}{|c|}{14 才 } & \multirow{2}{*}{$\begin{array}{l}15 \\
\mathrm{~N}\end{array}$} & \multirow{2}{*}{$\frac{才}{\%}$} & \multicolumn{2}{|l|}{16} & \multicolumn{2}{|r|}{ 才 } & \multicolumn{2}{|l|}{18} & \multicolumn{2}{|c|}{ 計 } \\
\hline & No. & 別 & No, & 沈着 & $\mathrm{N}$ & $\%$ & $\mathrm{~N}$ & $\%$ & $\mathrm{~N}$ & $\%$ & & & $\mathrm{~N}$ & $\%$ & $\mathrm{~N}$ & $\%$ & $\mathrm{~N}$ & $\%$ & $\mathbf{N}$ & $\%$ \\
\hline & & & 32 & - & & 40.1 & 36 & 38.3 & 33 & 333.7 & 22 & 34.4 & 32 & 29.9 & 34 & .5 & 19 & 0.5 & 190 & 4.5 \\
\hline & 29 & & 33 & \pm & & 37.1 & 40 & 42.5 & & 31.6 & 22 & 34.4 & 47 & 3.9 & 49 & .4 & 22 & 5.8 & 224 & 40.7 \\
\hline & & & 34 & + & & 2.8 & 1 & 1. 1 & 0 & 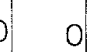 & 0 & 0 & ? & 1.8 & 0 & 0 & 1 & .1 & 5 & 0.6 \\
\hline & & & 32 & - & & 11.4 & 6 & 6.4 & & 323.5 & 11 & 7.2 & 12 & 2 & 6 & 5.5 & 1 & 1 & 63 & 11.4 \\
\hline & 30 & 歯肉炎 & 33 & \pm & & 8.6 & 10 & 10.6 & & 99.2 & 7 & 10.9 & 11 & 0.3 & 15 & 13.9 & 4 & 8.5 & 59 & 0.7 \\
\hline & & & 34 & † & & 0 & 0 & 0 & 0 & 0 & 0 & 0 & 0 & 0 & 0 & 0 & 0 & 0 & 0 & 0 \\
\hline & & & 3. & & & 0 & 1 & 1.1 & 1 & \begin{tabular}{|l|l|}
1.0 \\
\end{tabular} & 0 & o & 1 & 0.9 & 3 & 2.8 & 0 & 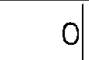 & 6 & 1.1 \\
\hline & 31 & 膿 & 33 & \pm & 0 & & 0 & 0 & 1 & 1.0 & 2 & 3.1 & 2 & 2.8 & 1 & 0.9 & 0 & 0 & 6 & 1.0 \\
\hline & & & 34 & & & & 0 & 0 & 0 & 0 & 0 & 0 & 0 & 0 & 0 & 0 & 0 & 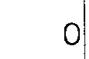 & 0 & 0 \\
\hline & & & 3. & - & & 52.5 & 68 & 41.7 & & 342.8 & 64 & 50.0 & 39 & 37.9 & 34 & 8.2 & 29 & 6.0 & 359 & 4.2 \\
\hline & 29 & & 33 & \pm & & 22.9 & & 26.9 & & 725.2 & 35 & 27.3 & 25 & 24.3 & 26 & 29.2 & 17 & 27.0 & 211 & 26.0 \\
\hline & & & 34 & + & & 1.7 & 5 & 3.1 & 4 & \pm 2.7 & 4 & 3. 1 & 3 & 2.9 & 1. & 1.1 & 1 & 1.6 & 20 & 2.6 \\
\hline & & & 32 & - & & 13.5 & & 18.4 & & $0 \mid 13.6$ & 14 & 10.9 & 20 & 19.4 & 11 & 12.3 & 4 & 11.1 & 118 & 14.5 \\
\hline & 30 & 崡肉炎 & 33 & \pm & & 7.6 & 11 & 6.7 & 19 & 9 & 8 & 6.2 & 10 & 9.7 & 10 & 11.3 & 8 & 12.7 & 75 & 9.2 \\
\hline & & & 34 & 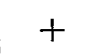 & & 0.9 & 1. & 0.7 & o & 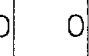 & 0 & 0 & O & 0 & 0 & 0 & 0 & 0 & 2 & 0.3 \\
\hline & & & 32 & & & 0.9 & & 1.8 & 2 & \begin{tabular}{l|l}
2 & 1.4
\end{tabular} & 2 & 1.6 & 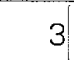 & 2.9 & 6 & 0.1 & o & 0 & 17 & 2.1 \\
\hline & 31 & & 33 & \pm & & & 1 & 0.7 & 2 & 21.4 & 1 & 0.9 & 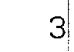 & 2.9 & 1 & 1.2 & & 1.6 & 9 & 1.1 \\
\hline & & & 34 & + & & & 0 & & 0 & 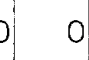 & 0 & & J & t & 0 & o & & 0 & & 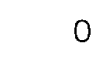 \\
\hline
\end{tabular}

表13

歯

石

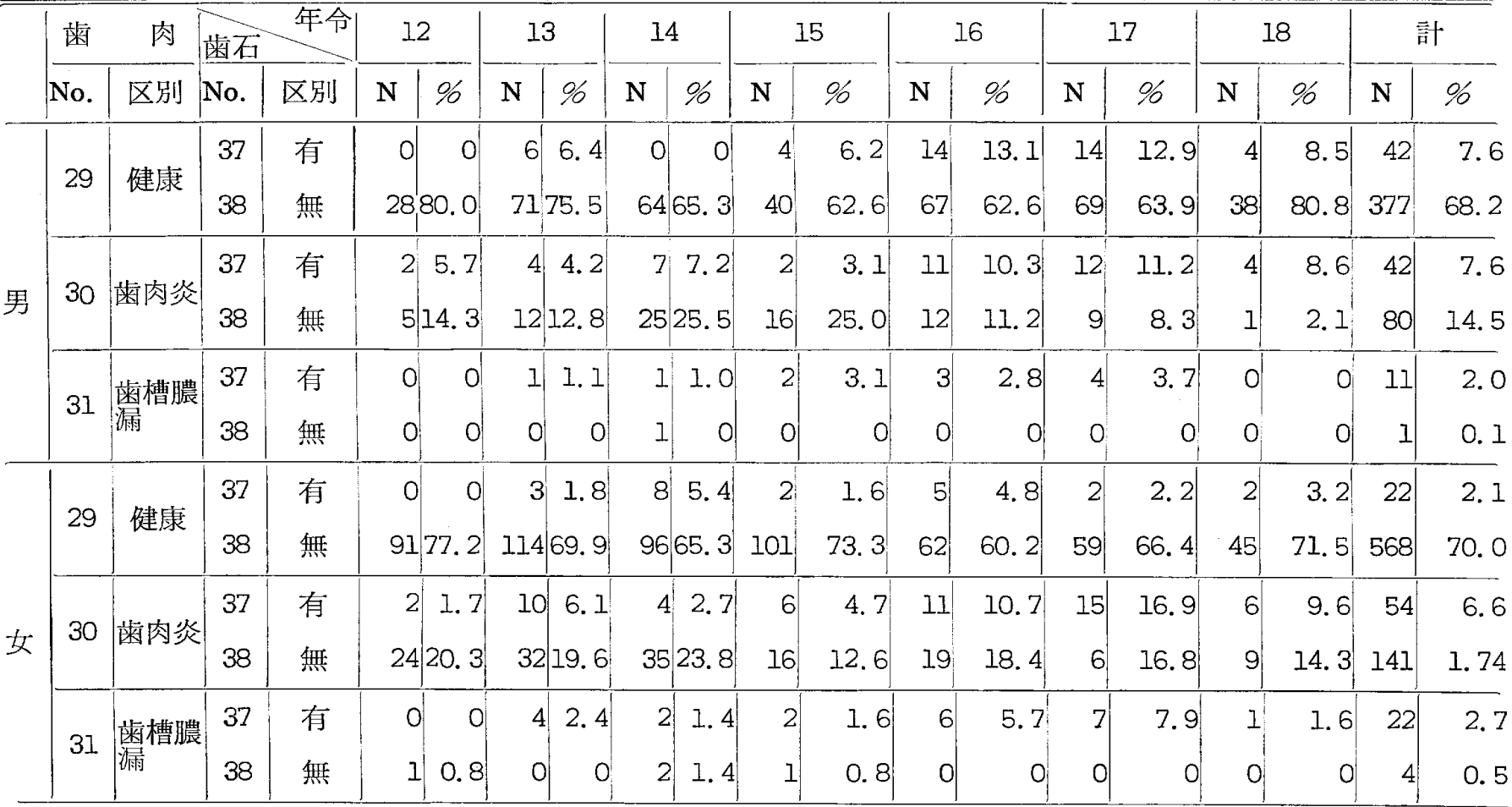


沈着物を全く認めないあのは，男が3.8\%，女が $7.9 \%$ で，全靧に沈着のあらわれるあのは，男が $65.9 \%$ ，女 が64.2\%であったといっている。原（1963）10)は雨石が 健康㐘肉にみられたのは, 11〜18才で1.6〜10.4\%，歯 肉笑患をむつ歯肉にみられたのは，11才で21.6\%，15才 で49.5\%，18才で63.0\%であったと報告した。茂田（ 1967）23)は歯石の有無が歯槽膿漏症の発病率を左右する
のではなく，口腔清掃の可否が左右すると発表してい る，著者の調査では歯石沈着は男が17.7\%，女が12.1\% である。

$5 \chi^{2}$ 一検定

歯肉疾患と Stippling, Melanin 色素沈着および歯石 との関係をみるために， $x^{2}$ 一検定を沶こなった。 その 結果は表14，15，16のとおりである．両者の間に関係の 表14

Stippling と歯肉の健康との関係

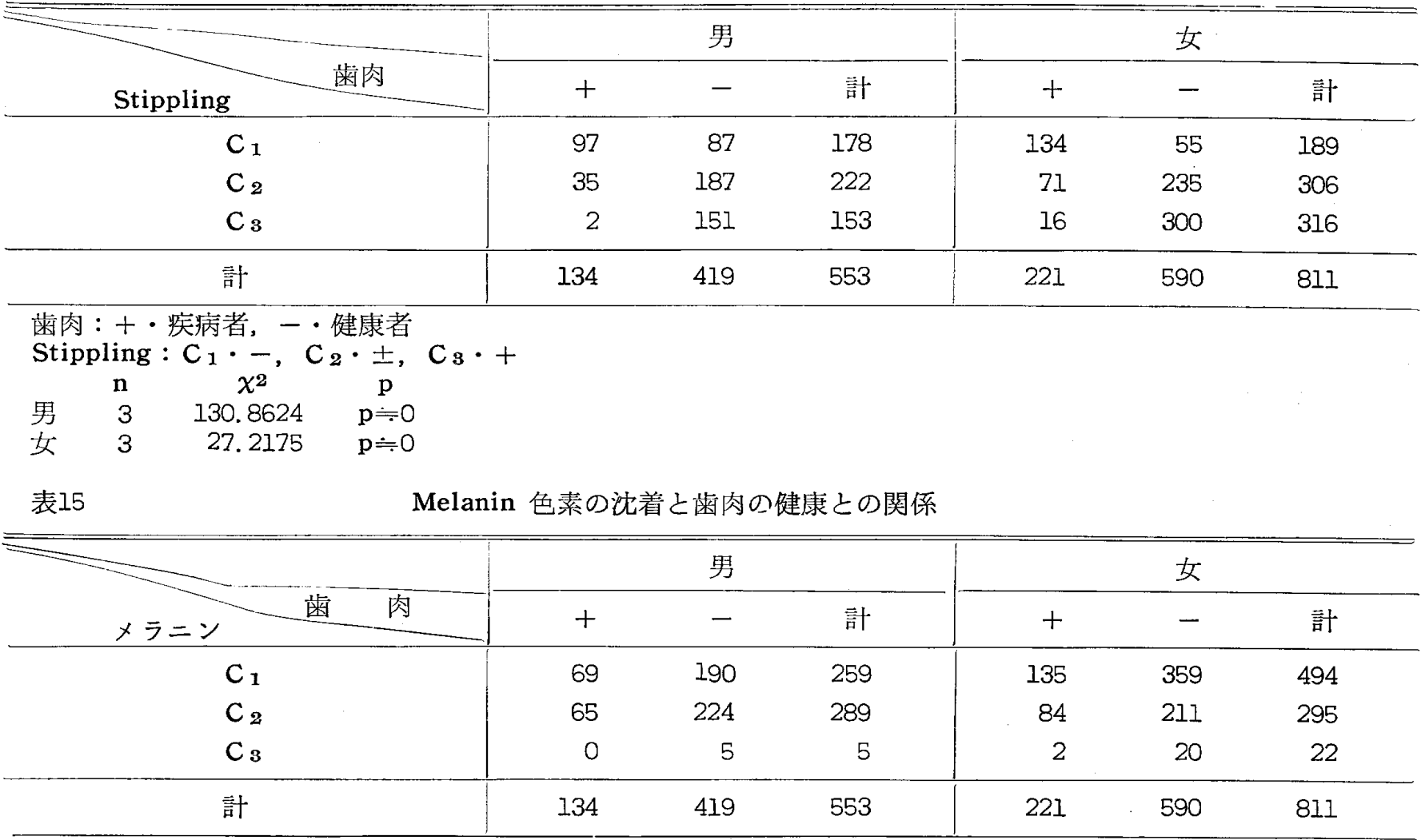

歯肉：十・疾病者, 一・健康者

Melanin : $\mathrm{C}_{1} \cdot-\mathrm{C}_{2} \cdot \pm, \mathrm{C}_{3} \cdot+$

$\begin{array}{cccc} & \mathbf{n} & \boldsymbol{x}^{2} & \mathbf{p} \\ \text { 男 } & 3 & 2.7554 & 0.50>\mathbf{p}>0.30 \\ \text { 女 } & 3 & 4.5050 & 0.30>\mathbf{p}>0.20\end{array}$

歯石之歯肉の健康との関係

\begin{tabular}{|c|c|c|c|c|c|c|}
\hline \multirow{2}{*}{ 歯 石 歯 肉 } & \multicolumn{3}{|c|}{ 男 } & \multicolumn{3}{|c|}{ 女 } \\
\hline & + & - & 計 & + & - & 計 \\
\hline $\mathrm{C}_{1}$ & 53 & 42 & 95 & 76 & 22 & 98 \\
\hline $\mathrm{C}_{2}$ & 81 & 377 & 458 & 145 & 568 & 713 \\
\hline 訫 & 134 & 419 & 553 & 221 & 590 & 811 \\
\hline
\end{tabular}

㐘肉: 十・疾病者，一健康者

䨑石: $\mathrm{C}_{1}$ ・有, $\mathrm{C}_{2} \cdot$ 無

$\begin{array}{cccc} & \mathrm{n} & \chi^{2} & \mathrm{p} \\ \text { 男 } & 2 & 487.3500 & \mathrm{p} \doteqdot 0 \\ \text { 女 } & 2 & 141.9406 & \mathrm{p} \doteqdot 0\end{array}$


あるむのは，男女とも Stippling $(\mathrm{P}=\mathrm{O})$ と㐘石（P ○)であった。

Melanin 色素沈着は男女とも関係は少ないようであ る. (男: P0.5>P0.3, 女 : $0.3>$ PO. 2).

〔II】食物の鄞好乙歯肉の健康状態についての調查成 績
1 高温食物嗜好亡歯肉の健康状態

崡肉の健康状態亡高温食物のすき, 普通, きらいとの 関係は，表17のとおりである.

歯肉の健康者，および歯肉炎をもつものは，男女之も 高温食物のすきなむの之普通なむのに著しく，きらいな ものにはほとんど見当らなかった，歯槽膿漏症は男女と

表17

高温食物嗜好上歯肉の健康状態

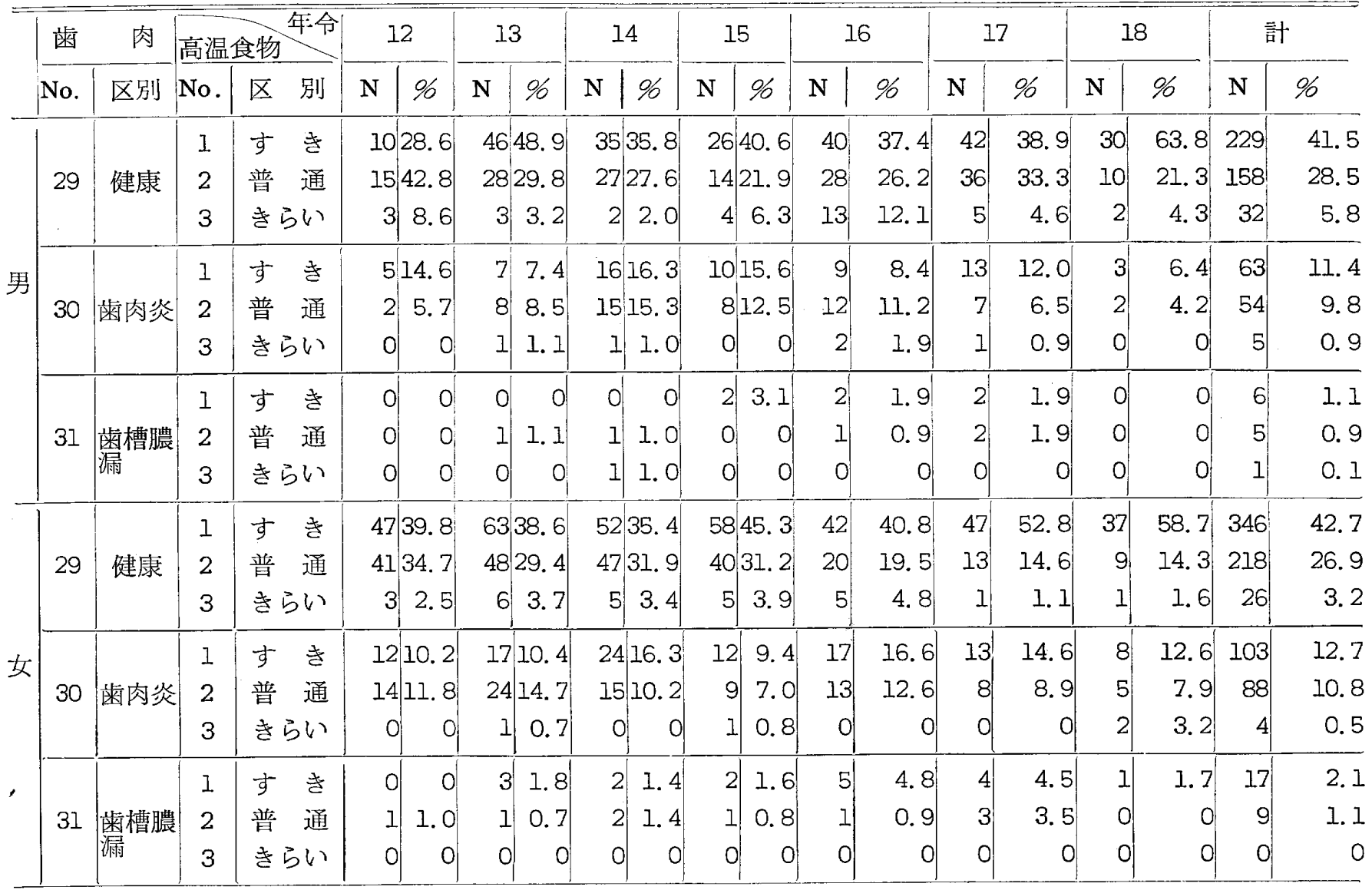

むに例数が少なく，高温食物のすきなものときらいなも のとの間でその霍患率に差があるか否かをあきらかにす ることはできなかった。

2 いわゆる猫舌と歯肉の煡康状態

歯肉の健康状態乞猫舌か否かとの関係は表180と拈り である．猫舌のものの全体に対する割合は小さく，この 割合は男女とも増令によりあまり変化しない。

\section{3 甘味食物嗜好亡歯肉の健康状態}

歯肉の健康者, 歯肉炎执よび歯槽膿漏症をもつもの別 にみた，甘味食物のすき，きらいの百分比は，表190と おりである。男女とも歯肉の健康者, 崡肉炎および歯槽 膿漏症をもつもののいずれにおいても，甘味のすきなす のがきらいなものよりも多い.
4 辛味食物嗜好乞歯肉の健康状態

歯肉の健康状態と辛味食物のすき,きらいとの関係 は，表20のとおりである。

茂田（1967）23)は辛味を好むものは，男女ともいずれ あう蝕をもつものにもっとも多く，歯槽膿漏症をむつも の, 健康なむのの順に少ない。

男女亡6歯肉の健康者, 歯肉炎をもつものに辛味食物 の好きなものが嫌いなものよりも多く認められるが雪槽 膿漏症をむつものには，辛味に対するすき，きらいの差 があまり認められない.

\section{5 硬質食物嗜好と歯肉の健康状態}

雪肉の健康状態と硬質食物のすき, 普通, きらいとの 関係は，表21の亡扣りである。歯肉の健康者，米肉炎お よび歯槽膿漏症をもつ屯ののいずれにも，硬質食物のす 


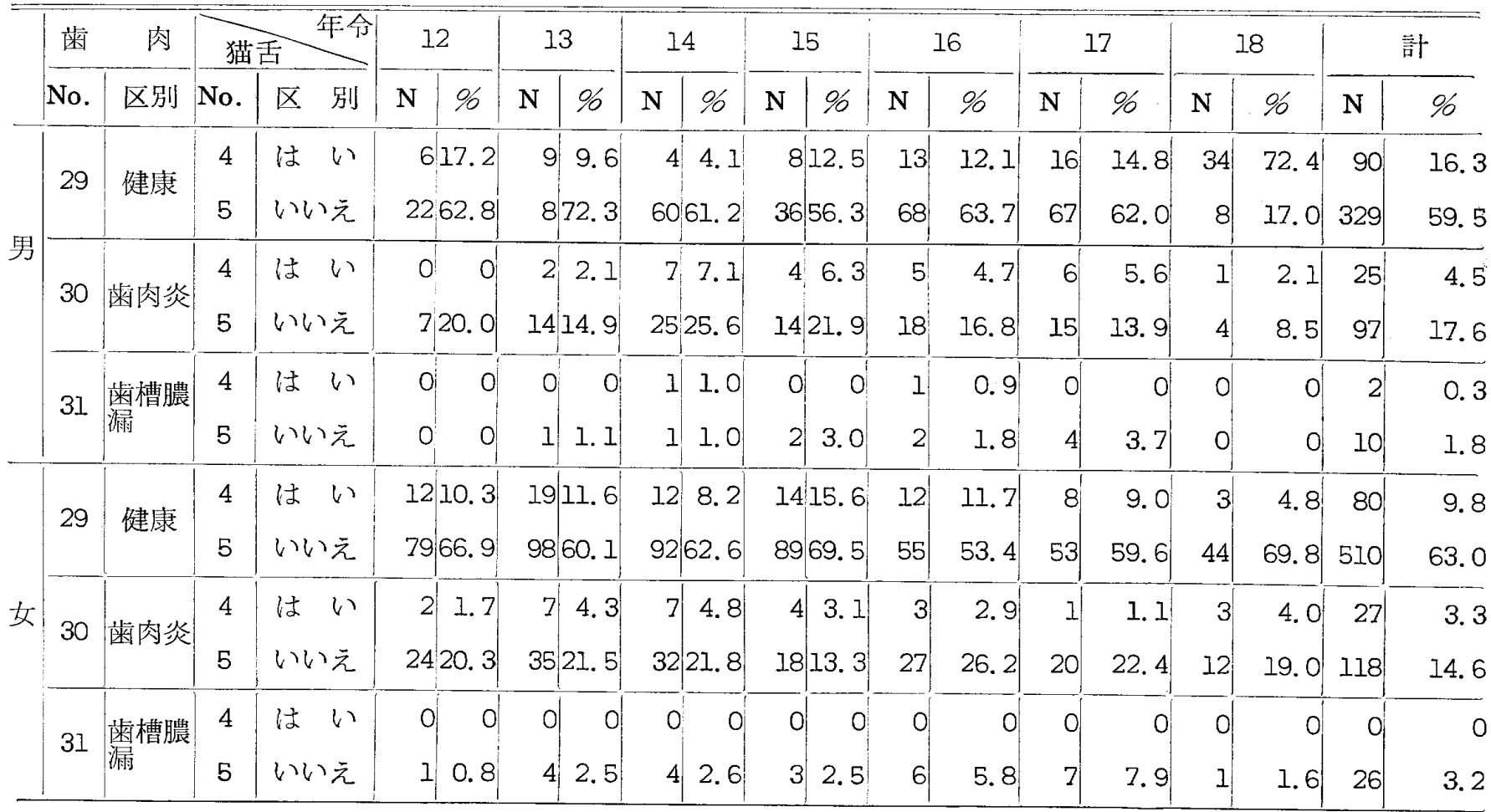

\begin{tabular}{|c|c|c|c|c|c|c|c|c|c|c|c|c|c|c|c|c|c|c|c|c|}
\hline & \multirow{2}{*}{$\frac{\text { 歯 }}{\text { Jo. }}$} & 肉 & \multicolumn{2}{|c|}{ 甘味食物 } & \multicolumn{2}{|c|}{12} & \multicolumn{2}{|c|}{13} & \multicolumn{2}{|c|}{14} & \multicolumn{2}{|c|}{15} & \multicolumn{2}{|c|}{16} & \multicolumn{2}{|c|}{17} & \multicolumn{2}{|c|}{18} & \multicolumn{2}{|c|}{ 計 } \\
\hline & & 区別 & No. & 区 別 & $\mathrm{N}$ & 96 & $\mathrm{~N}$ & $\%$ & $\mathrm{~N}$ & $\%$ & $\mathrm{~N}$ & $\%$ & $\mathrm{~N}$ & $\%$ & $\mathrm{~N}$ & $\%$ & $\mathrm{~N}$ & $\%$ & $\mathrm{~N}$ & $\%$ \\
\hline & & \multirow{2}{*}{ 健康 } & 12 & すき & \multirow{2}{*}{\multicolumn{2}{|c|}{\begin{tabular}{r|r}
23 & 65.7 \\
5 & 14.3
\end{tabular}}} & \multirow{2}{*}{\multicolumn{2}{|c|}{\begin{tabular}{l|l|}
55 & 58.5 \\
22 & 23.4 \\
\end{tabular}}} & \multirow{2}{*}{\multicolumn{2}{|c|}{$\begin{array}{r}49 \\
50.0 \\
15 \\
15.4\end{array}$}} & \multirow{2}{*}{\multicolumn{2}{|c|}{$\begin{array}{r}365.3 \\
812.5\end{array}$}} & \multirow{2}{*}{$\begin{array}{r}75 \\
6\end{array}$} & \multirow{2}{*}{$\begin{array}{r}70.1 \\
5.6\end{array}$} & \multirow{2}{*}{$\begin{array}{l}67 \\
16\end{array}$} & \multirow{2}{*}{$\begin{array}{l}62.1 \\
14.8\end{array}$} & \multirow{2}{*}{$\begin{array}{r}33 \\
9\end{array}$} & \multirow{2}{*}{$\begin{array}{l}70.2 \\
19.2\end{array}$} & \multirow{2}{*}{\begin{tabular}{|r|}
338 \\
81
\end{tabular}} & \multirow{2}{*}{$\begin{array}{l}61.1 \\
14.7\end{array}$} \\
\hline & & & 13 & きらい & & & & & & & & & & & & & & & & \\
\hline & \multirow{2}{*}{30} & \multirow{2}{*}{ 歯肉焱 } & 12 & すき & \multirow{2}{*}{\multicolumn{2}{|c|}{$\begin{array}{r}6 \\
17.1 \\
1 \\
2.9 \\
\end{array}$}} & \multirow{2}{*}{\multicolumn{2}{|c|}{\begin{tabular}{r|r|}
13 & 13.8 \\
3 & 3.2 \\
\end{tabular}}} & \multirow{2}{*}{\multicolumn{2}{|c|}{\begin{tabular}{l|l|}
16 & 16.3 \\
16 & 16.3
\end{tabular}}} & & 20.3 & 19 & 17.8 & 13 & 12.0 & 4 & 8.5 & 84 & 5.2 \\
\hline & & & 15 & きらい & & & & & & & & 7.8 & 4 & 3.7 & 8 & 7.4 & 1 & 2.1 & 38 & 6.9 \\
\hline & 3 & & 1 & すき & 0 & 0 & 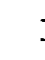 & 1.1 & 2 & 2.0 & 2 & 3.1 & 3 & 2.8 & 4 & 3.7 & 0 & 0 & 12 & 2.1 \\
\hline & 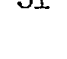 & & $1:$ & きらい & 0 & 0 & c & 0 & c & 0 & 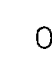 & o & 0 & & o 이 & 4 & 0 & 0 & & 0 \\
\hline & & & 1 & すき & & 55. I & or & 9.1 & & 51.0 & & 62.5 & 56 & 54.4 & 45 & 50.6 & 33 & 52.4 & 434 & 53.6 \\
\hline & 29 & & 13 & きらい & & 2.1 & 37 & 22.7 & & 19.7 & & 17.9 & 11 & 10.7 & 16 & 17.9 & 14 & 22,3 & 156 & 19.2 \\
\hline & 3 & & 1 & すき & & 16.1 & & 18.4 & & 12.2 & & 15.7 & 25 & 24.3 & 18 & 20.2 & 10 & 15.8 & 150 & 18.5 \\
\hline & $\pi$ & 众炎 & 13 & きらい & & 5.9 & 12 & 7.4 & 1] & 7.5 & & 1.6 & 5 & 4.8 & 3 & 3.4 & 5 & 7.9 & 45 & 5.5 \\
\hline & 27 & & & き & 1 & 0.8 & 3 & 1.8 & 3 & 2.1 & & 2.3 & 6 & 5.8 & 4 & 4.5 & 1 & 1.6 & 21 & 2.6 \\
\hline & & & 13 & きらい & & 0 & . & 0.6 & 1 & 0.7 & 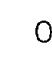 & 4 & 0 & & 3 & 3.4 & 0 & 0 & 5 & 0.6 \\
\hline
\end{tabular}


表20

辛味食物嗜好と雬肉の健康状態

\begin{tabular}{|c|c|c|c|c|c|c|c|c|c|c|c|c|c|c|c|c|c|c|c|c|}
\hline \multicolumn{3}{|c|}{ 歯 肉 } & \multicolumn{2}{|c|}{$\begin{array}{ll}\text { 辛味 } & \text { 年令 } \\
\end{array}$} & \multicolumn{2}{|c|}{12} & \multicolumn{2}{|r|}{13} & \multicolumn{2}{|r|}{4} & & \multicolumn{2}{|r|}{6} & \multicolumn{2}{|c|}{17} & \multicolumn{2}{|c|}{18} & \multicolumn{2}{|c|}{ 計 } \\
\hline & No. & 区別 & No. & 区 別 & $\mathbf{N}$ & $\%$ & $\mathrm{~N}$ & $\%$ & $\mathrm{~N}$ & $\%$ & $\mathbf{N}$ & $\%$ & $\mathrm{~N}$ & $\%$ & $\mathrm{~N}$ & $\%$ & $\mathrm{~N}$ & $\%$ & $\mathrm{~N}$ & \% \\
\hline & \multirow{2}{*}{29} & \multirow{2}{*}{ 健康 } & 14 & すき & \multirow{2}{*}{\multicolumn{2}{|c|}{$\begin{array}{r}22 \\
6 \quad 62.9 \\
17.2\end{array}$}} & \multirow{2}{*}{\multicolumn{2}{|c|}{$\begin{array}{r}6164.9 \\
1617.0 \\
\end{array}$}} & \multirow{2}{*}{\multicolumn{2}{|c|}{\begin{tabular}{l|l|l|}
49 & 50.0 \\
15.3 & 15 \\
\end{tabular}}} & \multirow{2}{*}{\multicolumn{2}{|c|}{\begin{tabular}{r|r|}
38 & 59.4 \\
6 & 9.4 \\
\end{tabular}}} & \multirow{2}{*}{$\begin{array}{l}69 \\
12\end{array}$} & 64.5 & \multirow{2}{*}{$\begin{array}{l}70 \\
13\end{array}$} & \multirow{2}{*}{$\begin{array}{l}64.8 \\
12.1\end{array}$} & \multirow{2}{*}{$\begin{array}{r}35 \\
7\end{array}$} & \multirow{2}{*}{$\begin{array}{l}74.5 \\
14.9\end{array}$} & \multirow{2}{*}{$\begin{array}{r}344 \\
75\end{array} \mid$} & \multirow{2}{*}{$\begin{array}{l}62.2 \\
13.6\end{array}$} \\
\hline & & & 15 & きらい & & & & & & & & & & 11.2 & & & & & & \\
\hline & \multirow{5}{*}{$3]$} & \multirow{2}{*}{ 崡肉炎 } & 14 & す & \multirow{2}{*}{\multicolumn{2}{|c|}{\begin{tabular}{|l|l|}
5 & 14.2 \\
2 & 5.7 \\
\end{tabular}}} & \multirow{3}{*}{\multicolumn{2}{|c|}{\begin{tabular}{r|r|}
12 & 12.7 \\
4 & 4.3 \\
\end{tabular}}} & \multirow{2}{*}{\multicolumn{2}{|c|}{\begin{tabular}{|r|r|}
26 & 26.5 \\
6 & 6.2 \\
\end{tabular}}} & \multirow{2}{*}{\multicolumn{2}{|c|}{\begin{tabular}{r|r|}
14 & 21.9 \\
4 & 6.3 \\
\end{tabular}}} & \multirow{2}{*}{$\begin{array}{r}21 \\
2 \\
\end{array}$} & 19.6 & 18 & 16.7 & 5 & 0.6 & 101 & 18.2 \\
\hline & & & 15 & きらい & & & & & & & & & & 1.9 & 3 & 2.8 & 0 & & 21 & 8.9 \\
\hline & & & & & & & & & & & & 76 & 4 & & & & & . & & \\
\hline & & 霜槽膿 & & & 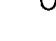 & & & & & & 1 & $\perp$ & 2 & & 2 & & & & b & \\
\hline & & & 15 & きらい & 0 & & I & 1.1 & & 2.0 & 1 & 1.6 & 1 & 0.9 & 2 & 1.8 & $\mathrm{O}$ & 0 & 7 & 1. 2 \\
\hline & & & 14 & す & & 68.6 & & 57.7 & & 1.2 & 89 & 69.5 & 57 & 55.4 & 57 & 64.0 & 44 & 69.8 & 512 & 63.2 \\
\hline & 25 & 健康 & 15 & きらい & & .5 & 23 & 14.1 & 14 & 9.5 & 14 & 10.9 & 10 & 9.7 & 4 & 4.5 & 3 & 4.8 & 78 & 8.6 \\
\hline & & & 14 & す き & & 18.6 & 37 & 22.7 & & 21.1 & & 14.2 & 27 & 26.3 & 18 & 20.2 & 14 & 22.2 & 167 & 20.6 \\
\hline & 30 & 料因炎 & & きらい & 4 & 3.4 & & 3. 1 & & 4.6 & 4 & 3.I & 3 & 2.9 & 3 & 3.4 & 1 & 1.6 & 28 & 3.3 \\
\hline & 3 & & 14 & す き & 1 & 0.9 & & 2.4 & & 2.0 & 3 & 2.3 & 5 & 4.8 & 5 & 5.6 & $1 \mid$ & 1.6 & 22 & 2.7 \\
\hline & $U_{1}$ & & 15 & きらし & 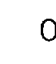 & & & & & 0. & 0 & & 1 & 0.9 & 2 & & & & 1 & 0.5 \\
\hline
\end{tabular}

表21

硬質食物と歯肉の健康状態

\begin{tabular}{|c|c|c|c|c|c|c|c|c|c|c|c|c|c|c|c|c|c|c|c|}
\hline \multicolumn{2}{|c|}{ 歯 肉 } & \multicolumn{2}{|c|}{ 硬質食物 } & \multicolumn{2}{|c|}{12} & \multicolumn{2}{|c|}{13} & \multicolumn{2}{|c|}{14} & \multicolumn{2}{|c|}{15} & \multicolumn{2}{|c|}{16} & \multicolumn{2}{|c|}{17} & \multicolumn{2}{|c|}{18} & \multicolumn{2}{|c|}{ 計 } \\
\hline No. & 区別 & No. & 区 別 & $\mathrm{N}$ & $\%$ & $\mathrm{~N}$ & $\%$ & $\mathrm{~N}$ & $\%$ & $\mathrm{~N}$ & $\%$ & $\mathrm{~N}$ & $\%$ & $\mathrm{~N}$ & $\%$ & $\mathrm{~N}$ & $\%$ & $\mathrm{~N}$ & $\%$ \\
\hline 29 & 健康 & $\begin{array}{l}6 \\
7 \\
8\end{array}$ & $\begin{array}{ll}\text { す } & \text { ( } \\
\text { 普 通 } \\
\text { きらい }\end{array}$ & $\begin{array}{r}16 \\
11 \\
1\end{array}$ & $\left|\begin{array}{l}45.7 \\
31.4 \\
2.9\end{array}\right|$ & $\begin{array}{r}49 \\
23 \\
5\end{array}$ & \begin{tabular}{|r|}
52.1 \\
24.5 \\
5.3
\end{tabular} & \begin{tabular}{r|}
37 \\
24 \\
3
\end{tabular} & $\left|\begin{array}{r}37.8 \\
24.5 \\
3.1\end{array}\right|$ & $\begin{array}{r}27 \\
15 \\
2\end{array}$ & $\begin{array}{l}42.3 \\
23.4 \\
3.1\end{array}$ & $\begin{array}{r}41 \\
33 \\
7\end{array}$ & $\begin{array}{r}38.3 \\
30.8 \\
6.5\end{array}$ & $\begin{array}{r}52 \\
29 \\
2\end{array}$ & $\begin{array}{r}48.1 \\
26.8 \\
1.9 \\
\end{array}$ & $\begin{array}{r}29 \\
10 \\
3\end{array}$ & $\begin{array}{r}61.6 \\
21.3 \\
6.4 \\
\end{array}$ & $\begin{array}{r}251 \\
145 \\
23 \\
\end{array}$ & $\begin{array}{r}45.4 \\
26.2 \\
4.2\end{array}$ \\
\hline 30 & 崡肉炎 & $\begin{array}{l}6 \\
7 \\
8\end{array}$ & $\begin{array}{cc}す & \text { き } \\
\text { 普 } & \text { 通 } \\
\text { きらい }\end{array}$ & $\begin{array}{l}5 \\
2 \\
0\end{array}$ & $\begin{array}{r}14.3 \\
5.7 \\
0\end{array}$ & \begin{tabular}{r|}
1 \\
5 \\
0
\end{tabular} & $\begin{array}{r}11.7 \\
5.3 \\
0\end{array}$ & \begin{tabular}{r|}
21 \\
11 \\
0
\end{tabular} & $\begin{array}{r}21.4 \\
11.2 \\
0\end{array}$ & $\begin{array}{r}12 \\
6 \\
0\end{array}$ & \begin{tabular}{r|}
8.7 \\
9.4 \\
0
\end{tabular} & $\begin{array}{r}12 \\
9 \\
2\end{array}$ & $\begin{array}{r}11.2 \\
8.4 \\
1.8\end{array}$ & $\begin{array}{r}15 \\
5 \\
1\end{array}$ & $\begin{array}{r}13.9 \\
4.6 \\
0.9\end{array}$ & $\begin{array}{l}2 \\
3 \\
0\end{array}$ & $\begin{array}{r}4.3 \\
6.4 \\
0\end{array}$ & $\begin{array}{r}78 \\
41 \\
3\end{array}$ & $\begin{array}{r}14.2 \\
7.4 \\
0.5\end{array}$ \\
\hline 31 & |雿槽膿 & $\begin{array}{l}6 \\
7 \\
8\end{array}$ & $\begin{array}{ll}\text { す } & \text { } \\
\text { 普 通 } \\
\text { きらい }\end{array}$ & $\begin{array}{l}0 \\
0 \\
0\end{array}$ & $\begin{array}{l}0 \\
0 \\
0\end{array}$ & $\begin{array}{l}1 \\
0 \\
0\end{array}$ & $\left|\begin{array}{r}1.1 \\
0 \\
0\end{array}\right|$ & $\begin{array}{l}2 \\
0 \\
0\end{array}$ & $\begin{array}{r}2.0 \\
0 \\
0\end{array}$ & $\begin{array}{l}0 \\
2 \\
0\end{array}$ & $\begin{array}{r}0_{1}^{\prime} \\
3.1 \\
0\end{array}$ & $\begin{array}{l}1 \\
1 \\
1\end{array}$ & $\begin{array}{l}1.0 \\
1.0 \\
1.0\end{array}$ & $\begin{array}{l}2 \\
2 \\
0\end{array}$ & $\begin{array}{r}1.9 \\
1.9 \\
0\end{array}$ & $\begin{array}{l}0 \\
0 \\
0 \\
0\end{array}$ & $\begin{array}{l}0 \\
0 \\
0\end{array}$ & $\begin{array}{l}6 \\
5 \\
1\end{array}$ & $\begin{array}{l}0.9 \\
0.2\end{array}$ \\
\hline 29 & 健康 & $\begin{array}{l}6 \\
7 \\
8 \\
\end{array}$ & $\begin{array}{ll}\text { す } & \\
\text { 普 通 } \\
\text { きらい }\end{array}$ & $\begin{array}{l}56 \\
33 \\
24\end{array}$ & $\begin{array}{r}47.6 \\
27.9 \\
1.7\end{array}$ & $\begin{array}{r}69 \\
46 \\
2\end{array}$ & \begin{tabular}{|r|}
42.3 \\
28.2 \\
1.3
\end{tabular} & & $\left|\begin{array}{r}40.2 \\
27.1 \\
3.4\end{array}\right|$ & $\begin{array}{r}62 \\
35 \\
6 \\
\end{array}$ & $\begin{array}{l}48.5 \\
27.3 \\
4.7\end{array}$ & $\begin{array}{r}36 \\
28 \\
3\end{array}$ & $\begin{array}{r}34.9 \\
27.2 \\
2.9\end{array}$ & $\begin{array}{r}42 \\
18 \\
1\end{array}$ & $\begin{array}{r}47.3 \\
20.2 \\
1.1\end{array}$ & $\begin{array}{r}31 \\
16 \\
0\end{array}$ & $\begin{array}{r}49.2 \\
25.4 \\
0\end{array}$ & $\begin{array}{r}355 \\
216 \\
19\end{array}$ & $\begin{array}{r}43.7 \\
26.8 \\
2.3 \\
\end{array}$ \\
\hline 30 & 雷肉炎 & $\begin{array}{l}6 \\
7 \\
8\end{array}$ & $\begin{array}{ll}\text { す } & \text { き } \\
\text { 普 } & \text { 通 } \\
\text { さらい }\end{array}$ & $\begin{array}{r}14 \\
12 \\
0\end{array}$ & $\begin{array}{r}11.8 \\
10.2 \\
0\end{array}$ & $\begin{array}{r}25 \\
15 \\
2\end{array}$ & $\begin{array}{r}15.3 \\
9.2 \\
1.3\end{array}$ & \begin{tabular}{r|}
20 \\
16 \\
3
\end{tabular} & $\begin{array}{r}13.6 \\
10.9 \\
2.0\end{array}$ & $\begin{array}{r}8 \\
14 \\
0\end{array}$ & $\begin{array}{r}6.2 \\
0.9 \\
0\end{array}$ & $\begin{array}{r}18 \\
11 \\
1\end{array}$ & $\begin{array}{r}17.4 \\
10.7 \\
1.0\end{array}$ & $\begin{array}{r}13 \\
6 \\
2\end{array}$ & $\begin{array}{r}14.7 \\
6.7 \\
2.2\end{array}$ & $\begin{array}{l}9 \\
6 \\
0\end{array}$ & $\begin{array}{r}14.3 \\
9.5 \\
0\end{array}$ & $\begin{array}{r}107 \\
80 \\
8\end{array}$ & $\begin{array}{r}13.2 \\
9.8 \\
1.0\end{array}$ \\
\hline 31 & $\mid$ & $\begin{array}{l}6 \\
7 \\
8\end{array}$ & $\begin{array}{ll}\text { す } & \text { き } \\
\text { 普 } & \text { 通 } \\
\text { きらい }\end{array}$ & $\begin{array}{l}1 \\
0 \\
0\end{array}$ & $\begin{array}{r}0.8 \\
0 \\
0\end{array}$ & $\begin{array}{l}4 \\
0 \\
0\end{array}$ & $\begin{array}{r}2.4 \\
0\end{array}$ & $\begin{array}{l}2 \\
2 \\
0\end{array}$ & $\begin{array}{r}1.4 \\
1.4 \\
0\end{array}$ & $\begin{array}{l}1 \\
2 \\
0\end{array}$ & \begin{tabular}{r|}
0.8 \\
1.6 \\
0
\end{tabular} & $\begin{array}{l}4 \\
1 \\
1\end{array}$ & $\begin{array}{l}3.9 \\
1.0 \\
1.0\end{array}$ & $\begin{array}{l}5 \\
2 \\
0\end{array}$ & $\begin{array}{r}5.6 \\
2.2 \\
0\end{array}$ & $\begin{array}{l}1 \\
0 \\
0\end{array}$ & $\begin{array}{r}1.6 \\
0 \\
0\end{array}$ & $\begin{array}{r}18 \\
7 \\
1\end{array}$ & $\begin{array}{l}2.2 \\
0.9 \\
0.1\end{array}$ \\
\hline
\end{tabular}


きならびに普通なものが圧倒的に多く，きらいなもの は非常に少ない。

石川他（1962）4）は日本猿の野生のもの之長期間飼育 したものの 2 群について, 歯肉炎の有病率を観察し, 野 生の方が長期間飼育より屯歯肉炎は低率で，また㐘肉炎 の PMA 指数は増令的に増加すると述へている。 Burwasser $亡$ Hill24) は，化学的には全く同一の組成で, 硬 さのちがう食品を 2 群の犬に長期間与え，それらの食物 の㐘肉に扔よばす影響を観察している。すなわち，ドッ クビスケットを硬いままのものと水にひたして軟かくし たものを与えた場合，後者の方が㐘石，雬垢の沈着が多 く, 歯肉は発生腫脹して, 容易に出血し, 口臭が強加っ た．硬いものを与えた方の歯肉は強く，しまったピンク 色の健康状態を保ったと発表している．L．M．Waugh （1928）25)による之，エスキモー人は白人文明の影響を うけて, 加工食品の摄取量が増加し, 食物中の炭水化物 の占める割合が大きくなり，蛋白質が少なくなるほど, う蝕とともに歯石沈着，歯肉疾患息增加する傾向にある という. 石川他（1962）4）金物自体が直接に局所原因 として大きな役割を占めているにいい，主として雨垢の 沈着，食渣の停滞，食片の圧入などを柴肉汇対する起炎
症性原因としてあげている。また食物の物理的性質によ る影響が大きく，食物を軟かい食品之硬い食品とにわけ て考えるてとができると発表している．河西（1966） 26) は犬の実験により軟加い飼料を与えたあのの方が，硬 い飼料を与えたものよりも，若干炎症所見が強いように 思わ扎たといっている，村下（1960）27は，う歯と歯槽 膿漏症との相反性に関する研究をおこない，甘味食物， 肉類，野菜類，酒について好むものは全体加らみると男 女とむう蝕が多く，ついで歯槽膿漏症が多いといってい る.

\section{6 軟質食物嗜好之歯肉の健康状態}

歯肉の健康状態之軟質食物のすき，普通，きらいとの 関係は表22のとおりである, 男女とも歯肉の健康者, 歯 肉炎拉よび歯槽膿漏症をもつものには, 軟質食物のすき なむのと普通のものがきらいなものよりも多い．

\section{7 野菜類嗜好之䨤肉の健康状態}

歯肉の健康状態と野菜類のすき，きらいとの関係は， 表230と打りである。

男女と㐘肉の健康者, 歯肉炎扔よび歯槽膿漏症のい ずれも野菜類のすきなものがきらいなものよりも多い.

茂田（1967）23) は野菜を好むものは，女よりも男にや

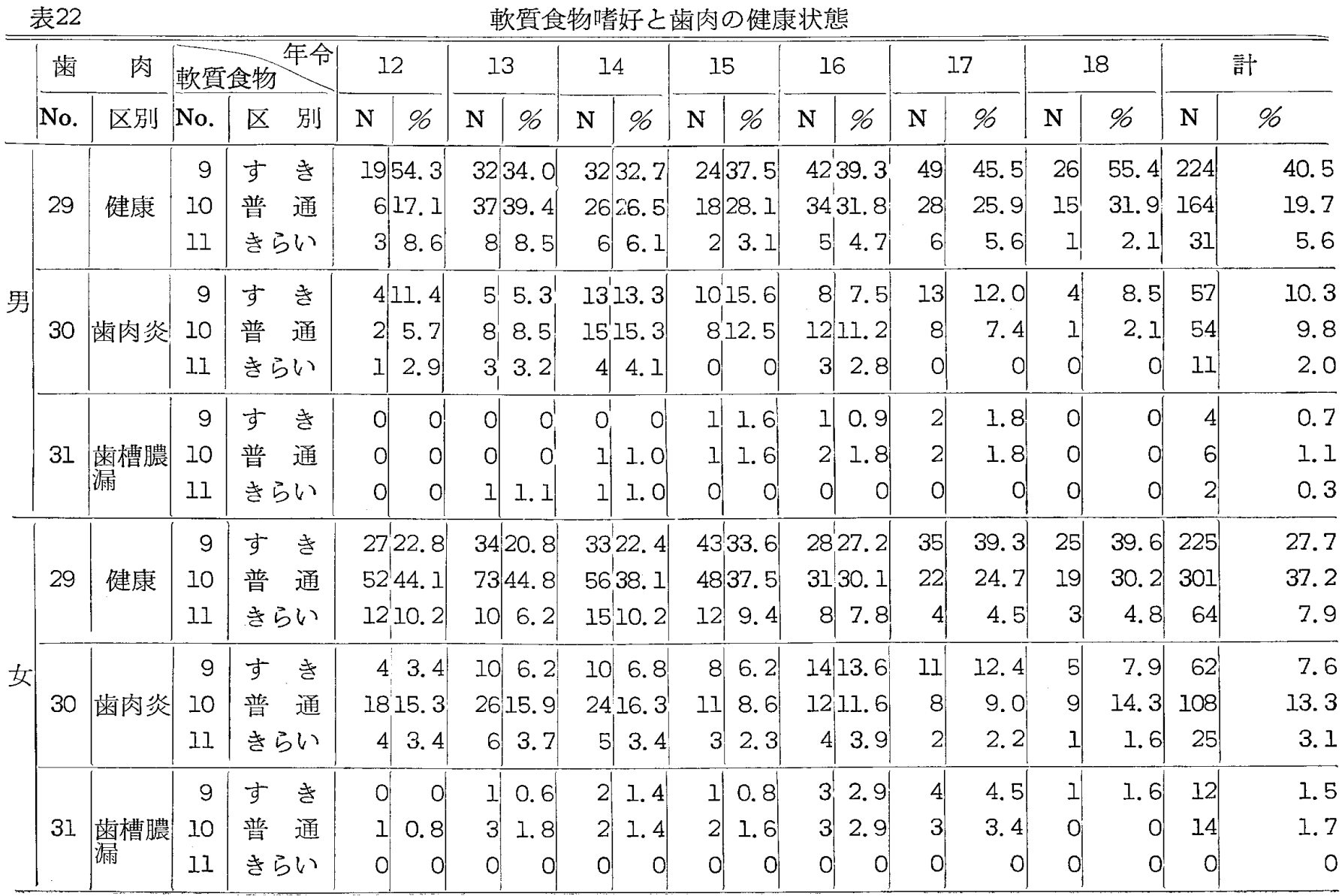




\begin{tabular}{|c|c|c|c|c|c|c|c|c|c|c|c|c|c|c|c|c|c|c|c|c|c|}
\hline \multicolumn{3}{|c|}{ 歯肉の所見 } & \multicolumn{2}{|c|}{ 野菜 年令 } & \multicolumn{2}{|c|}{12} & \multicolumn{2}{|r|}{13} & \multicolumn{2}{|r|}{4.4} & \multicolumn{3}{|c|}{15} & \multicolumn{2}{|c|}{16} & \multicolumn{2}{|c|}{17} & \multicolumn{2}{|c|}{18} & \multicolumn{2}{|c|}{ 計 } \\
\hline & No. & 区別 & No. & 区 別 & $\mathrm{N}$ & 96 & $\mathrm{~N}$ & $\%$ & $\mathrm{~N}$ & $\%$ & 1 & \% & 6 & $\mathrm{~N}$ & $\%$ & $\mathrm{~N}$ & $\%$ & $\mathrm{~N}$ & $\%$ & $\mathrm{~N}$ & $\%$ \\
\hline & & & I & & \multirow{2}{*}{\multicolumn{2}{|c|}{$\begin{array}{l}542.0 \\
337.0\end{array}$}} & \multirow{2}{*}{\multicolumn{2}{|c|}{\begin{tabular}{l|l|}
59 & 62.8 \\
18 & 19.1
\end{tabular}}} & \multirow{2}{*}{\multicolumn{2}{|c|}{$\begin{array}{l}5051.0 \\
14 \mid 14.3\end{array}$}} & \multirow{2}{*}{\multicolumn{3}{|c|}{$\begin{array}{r}41 \mid 64.1 \\
346.8\end{array}$}} & \multirow[b]{2}{*}{16} & 8 & \multirow{2}{*}{$\begin{array}{l}68 \\
15\end{array}$} & 9 & \multirow{2}{*}{$\begin{array}{r}38 \\
4\end{array}$} & 80.8 & \multirow{2}{*}{$\begin{array}{r}336 \\
83\end{array}$} & \multirow{2}{*}{$\begin{array}{l}60.8 \\
15.0\end{array}$} \\
\hline & & & 19 & きらい & & & & & & & & & & & 14.9 & & 13.9 & & 8.6 & & \\
\hline & & \multirow{2}{*}{ 歯肉炎 } & 18 & すき & \multirow{2}{*}{\multicolumn{2}{|c|}{\begin{tabular}{|c|c|}
5.3 \\
24.7 \\
\end{tabular}}} & \multirow{2}{*}{\multicolumn{2}{|c|}{\begin{tabular}{r|r|}
$14 \mid$ & 4.9 \\
$2 \mid$ & 2.1
\end{tabular} \mid}} & \multirow{2}{*}{\multicolumn{2}{|c|}{\begin{tabular}{|r|r|}
23 & 23.5 \\
9 & 9.2 \\
\end{tabular}}} & \multirow{2}{*}{\multicolumn{3}{|c|}{\begin{tabular}{r|r|}
12 & 18.7 \\
6 & 9.4 \\
\end{tabular}}} & \multirow{2}{*}{$\begin{array}{r}19 \\
4\end{array}$} & $17.8^{\prime}$ & \multirow{2}{*}{$\begin{array}{r}16 \\
5\end{array}$} & 14.9 & \multirow{2}{*}{$\begin{array}{l}5 \\
0\end{array}$} & 10.6 & & 17.0 \\
\hline & & & 19 & きらい & & & & & & & & & & & 3.7 & & 4.7 & & 0 & 28 & 5. \\
\hline & & & 18 & すき & o & 0 & & ) & & 1. & & 23 & .0 & 3 & 2.8 & 2 & 1.8 & 0 & o & 8 & 1.4 \\
\hline & 3. & & 1 & きらい & 0 & 0 & & 1. & & 1. & & 0 & 0 & 0 & 0 & 2 & 1.8 & 0 & 0 & 4 & 0.7 \\
\hline & & & 18 & すき & & 6.8 & & 59.5 & & 7. & & 3969. & & 61 & 59.2 & 57 & 64.0 & $44 \mid$ & 49.8 & 499 & 61.4 \\
\hline & 29 & 健氺 & 19 & きろい & & & & 12 & & 13. & & 1410 & & 6 & 5.8 & 4 & 4.6 & 3 & 4.8 & 91 & 11.4 \\
\hline & & & $\perp$ & すき & & 18.7 & & 21. & & 21. & & 1914. & & 26 & 25.3 & 15 & 16.9 & $13 \mid$ & 20.6 & 162 & 20.0 \\
\hline & 30 & 炃 & 19 & きらい & & 4 & & 4.3 & & 4. & & & .4 & 4 & 3.9 & 6 & 6.7 & 2 & 3.2 & 33 & 4.0 \\
\hline & & & 1 & すき & & 0.8 & & $\begin{array}{ll}3 & 1 .\end{array}$ & & 2. & & \begin{tabular}{l|l}
3 & 2
\end{tabular} & .4 & 5 & 4.9 & 6 & 6.7 & 1 & 1.6 & 23 & 28 \\
\hline & & & 19 & きらい & & 0 & & 0. & & 0 & & 0 & 0 & 1 & 0.9 & 1 & 1.1 & 0 & 0 & 3 & 0.4 \\
\hline
\end{tabular}

\begin{tabular}{|c|c|c|c|c|c|c|c|c|c|c|c|c|c|c|c|c|c|c|c|c|}
\hline \multicolumn{3}{|c|}{ 歯 肉 } & \multicolumn{2}{|c|}{ 肉類 } & \multicolumn{2}{|c|}{12} & \multicolumn{2}{|c|}{13} & \multicolumn{2}{|c|}{14} & \multicolumn{2}{|c|}{15} & \multicolumn{2}{|c|}{16} & \multicolumn{2}{|c|}{17} & \multicolumn{2}{|c|}{18} & \multicolumn{2}{|c|}{ 計 } \\
\hline & No. & 区別 & No. & 区 別 & $\mathrm{N}$ & $\%$ & $\mathrm{~N}$ & $\%$ & $\mathrm{~N}$ & $\%$ & $\mathrm{~N}$ & $\%$ & $\mathrm{~N}$ & $\%$ & $\mathrm{~N}$ & $\%$ & $\mathrm{~N}$ & $\%$ & $\mathrm{~N}$ & $\%$ \\
\hline & 29 & 健康 & $\begin{array}{l}16 \\
17\end{array}$ & $\begin{array}{l}\text { すき } \\
\text { きらい }\end{array}$ & & .0 & & $\begin{array}{l}1.3 \\
0.6\end{array}$ & & & & $\begin{array}{r}0.9 \\
7.8\end{array}$ & $\begin{array}{r}75 \\
6\end{array}$ & $\begin{array}{r}70.1 \\
5.6\end{array}$ & $\begin{array}{r}74 \\
9\end{array}$ & $\begin{array}{r}68.5 \\
8.3\end{array}$ & $\begin{array}{r}40 \\
2\end{array}$ & $\begin{array}{r}85.1 \\
4.3\end{array}$ & $\begin{array}{r}366 \\
53\end{array}$ & $\begin{array}{r}66.2 \\
9.6\end{array}$ \\
\hline & 30 & 歯肉炎 & $\begin{array}{l}16 \\
17\end{array}$ & $\begin{array}{l}\text { す } \\
\text { きらい }\end{array}$ & & $\begin{array}{r}17.1 \\
2.9\end{array}$ & & $\begin{array}{l}2.7 \\
4.3\end{array}$ & & $\begin{array}{r}26.5 \\
6.1\end{array}$ & & $\begin{array}{l}0.4 \\
7.8\end{array}$ & $\begin{array}{r}20 \\
3\end{array}$ & $\begin{array}{r}18.7 \\
2.8\end{array}$ & $\begin{array}{r}19 \\
2\end{array}$ & $\begin{array}{r}17.7 \\
1.8\end{array}$ & $\begin{array}{l}5 \\
0\end{array}$ & $\begin{array}{r}10.6 \\
0\end{array}$ & $\begin{array}{r}101 \\
21\end{array}$ & $\begin{array}{r}18.2 \\
3.9\end{array}$ \\
\hline & $3 I$ & |霉槽膿 & $\begin{array}{l}16 \\
17\end{array}$ & $\begin{array}{l}\text { す き } \\
\text { きい }\end{array}$ & 0 & 0 & 0 & $\begin{array}{r}0 \\
1.1\end{array}$ & 1 & $\begin{array}{l}1.0 \\
1.0\end{array}$ & 2 & $\begin{array}{r}3.1 \\
0\end{array}$ & $\begin{array}{l}3 \\
0\end{array}$ & \begin{tabular}{r|}
2.8 \\
0
\end{tabular} & 4 & \begin{tabular}{r|}
3.7 \\
0
\end{tabular} & 0 & $\begin{array}{l}0 \\
0\end{array}$ & $\begin{array}{r}10 \\
2\end{array}$ & $\begin{array}{l}1.8 \\
0.3 \\
\end{array}$ \\
\hline & 29 & 健康 & $\begin{array}{l}16 \\
17\end{array}$ & $\begin{array}{l}\text { す } \\
\text { きらい }\end{array}$ & & 25.1 & 87 & 3.4 & & $\begin{array}{r}60.3 \\
20.5\end{array}$ & & $\begin{array}{l}53.9 \\
26.6\end{array}$ & $\begin{array}{l}53 \\
14\end{array}$ & $\begin{array}{l}51.4 \\
13.6\end{array}$ & $\begin{array}{r}57 \\
4\end{array}$ & $\begin{array}{r}64.1 \\
4.5\end{array}$ & $\begin{array}{l}36 \\
11\end{array}$ & $\begin{array}{l}57.2 \\
17.5\end{array}$ & $\begin{array}{l}441 \\
149\end{array} \mid$ & $\begin{array}{l}50.3 \\
18.4\end{array}$ \\
\hline & 30 & 歯肉炎 & $\begin{array}{l}16 \\
17\end{array}$ & $\begin{array}{l}\text { す き } \\
\text { きらい }\end{array}$ & & $\begin{array}{l}18.6 \\
3.4\end{array}$ & 14 & $\begin{array}{r}17.2 \\
8.6\end{array}$ & 33 & $\begin{array}{r}2.4 \\
4.1\end{array}$ & 70 & $\begin{array}{l}14.8 \\
2.3\end{array}$ & $\begin{array}{r}26 \\
4\end{array}$ & $\begin{array}{r}25.2 \\
3.9\end{array}$ & $\begin{array}{r}19 \\
2\end{array}$ & $\begin{array}{r}21.4 \\
2.2\end{array}$ & $\begin{array}{r}10 \\
5\end{array}$ & $\begin{array}{r}15.8 \\
7.9\end{array}$ & $\begin{array}{r}157 \\
38\end{array}$ & $\begin{array}{r}19.3 \\
4.7\end{array}$ \\
\hline & 31 & 雿槽膿 & $\begin{array}{l}16 \\
17\end{array}$ & $\begin{array}{l}\text { す } \\
き ら い\end{array}$ & & $\begin{array}{r}0 \\
0.9\end{array}$ & 2 & $\begin{array}{l}1.2 \\
1.2\end{array}$ & 1 & $\begin{array}{l}2.1 \\
0.6\end{array}$ & 1 & $\begin{array}{l}1.6 \\
0.8\end{array}$ & $\begin{array}{l}4 \\
2\end{array}$ & $\begin{array}{l}3.9 \\
2.0\end{array}$ & 5 & $\begin{array}{l}5.6 \\
2.2\end{array}$ & 1 & $\begin{array}{r}1.6 \\
0\end{array}$ & $\begin{array}{r}17 \\
9\end{array}$ & $\begin{array}{l}2.1 \\
1.1\end{array}$ \\
\hline
\end{tabular}


や多く，歯槽膿漏症をむつものでは，野菜を好むあのが きらいなむのよりむ多いといっている。

8 肉類嗜好之雷肉の健康状態

菌肉の健康状態と肉類のすき,きらいとの関係は表 24 のと㧍りである。

男女とも歯肉の健康者, 歯肉炎打よび歯槽膿漏症をも つもののいずれに抢いてす，肉類のすきなものがきらい
なものよりも多い.

茂田（1967）23)は肉類を好むむのは，う蝕の多いもの にもっとあ多く，ついで歯槽膿漏症をむつもの，健康な あのの順に少ないといっている。

\section{9 魚類喏好之歯肉の健康状態}

歯肉の健康状態と魚類のすききらいとの関係は，表 25のとおりである.

\begin{tabular}{|c|c|c|c|c|c|c|c|c|c|c|c|c|c|c|c|c|c|c|c|c|}
\hline & & \multicolumn{2}{|c|}{ 魚類 ${ }^{\text {年令 }}$} & \multicolumn{2}{|c|}{12} & \multicolumn{2}{|c|}{13} & \multicolumn{2}{|c|}{14} & \multicolumn{2}{|c|}{15} & \multicolumn{2}{|c|}{16} & \multicolumn{2}{|c|}{17} & \multicolumn{2}{|c|}{18} & \multicolumn{2}{|c|}{ 計 } \\
\hline & No. & 区別 & No. & 区 別 & $\mathrm{N}$ & $\%$ & $\mathrm{~N}$ & $\%$ & $\mathrm{~N}$ & $\%$ & $\mathrm{~N}$ & $\mathscr{6}$ & $\mathrm{N}$ & $\%$ & $\mathrm{~N}$ & $\%$ & $\mathrm{~N}$ & $\%$ & $\mathrm{~N}$ & $\%$ \\
\hline & \multirow{2}{*}{2} & \multirow{2}{*}{ 健康 } & 20 & すき & \multirow{2}{*}{\multicolumn{2}{|c|}{\begin{tabular}{|l|}
3 \\
37.2 \\
52.8
\end{tabular}}} & \multirow{2}{*}{\multicolumn{2}{|c|}{\begin{tabular}{l|l|l|}
39 & 41.5 \\
38 & 40.4
\end{tabular}}} & \multirow{2}{*}{\multicolumn{2}{|c|}{$\begin{array}{r}3636.7 \\
2828.6\end{array}$}} & & \multirow{2}{*}{$\begin{array}{l}32.8 \\
35.9\end{array}$} & \multirow{2}{*}{$\begin{array}{l}49 \\
32\end{array}$} & 45.8 & \multirow{2}{*}{$\begin{array}{l}48 \\
35\end{array}$} & 44.4 & \multirow{2}{*}{$\begin{array}{l}21 \\
21\end{array}$} & \multirow{2}{*}{$\begin{array}{l}44.7 \\
44.7\end{array}$} & \multirow{2}{*}{$\begin{array}{l}227 \\
192\end{array}$} & \multirow{2}{*}{$\begin{array}{l}41.1 \\
34.7\end{array}$} \\
\hline & & & 21 & きらい & & & & & & & & & & 29.9 & & 32.4 & & & & \\
\hline & \multirow{2}{*}{30} & \multirow{2}{*}{ 㐘肉炎 } & 20 & すき & \multirow{2}{*}{\multicolumn{2}{|c|}{\begin{tabular}{l|l|}
5 & 14.3 \\
2 & 5.7
\end{tabular}}} & \multirow{2}{*}{\multicolumn{2}{|c|}{\begin{tabular}{r|r}
11 & 11.7 \\
5 & 5.3
\end{tabular}}} & \multirow{2}{*}{\multicolumn{2}{|c|}{\begin{tabular}{l|l}
17 & 17.3 \\
15 & 15.4
\end{tabular}}} & \multirow{2}{*}{\multicolumn{2}{|c|}{\begin{tabular}{r|r|}
15 & 23.4 \\
3 & 4.7
\end{tabular}}} & \multirow{2}{*}{$\begin{array}{r}9 \\
14\end{array}$} & 8.4 & 9 & 8.3 & 2 & 4.2 & 68 & 12.3 \\
\hline & & & 21 & きらい & & & & & & & & & & 13. 1 & 12 & 11.1 & 3 & 6.4 & 54 & 9.8 \\
\hline & & & 20 & すき & 0 & 0 & 0 & 0 & & & & 1.6 & 2 & 1.8 & 1 & 1.0 & of & 0 & 4 & 0.7 \\
\hline & 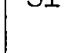 & & 21 & きらい & 0 & 0 & 1 & 1.1 & & 2.0 & & 1.6 & 1 & 1.0 & 3 & 2.8 & 0 & 0 & 8 & 1.4 \\
\hline & & & 20 & すき & & 45.8 & & $|37.4|$ & & 37.4 & & 35.9 & 31 & 30. I & 34 & 38.3 & 23 & 36.5 & 304 & 37.2 \\
\hline & 29 & 球 & 21 & きらい & & 31.4 & & 34.4 & & 33.3 & & 44.5 & 36 & 34.9 & 27 & 30.3 & 24 & 38.1 & 286 & 35.9 \\
\hline & & & 20 & すきき & & 16.1 & 16 & \begin{tabular}{|c|}
6 \\
5
\end{tabular} & & 15.6 & & 10.9 & 18 & 17.5 & 12 & 13.5 & 11 & 17.5 & 113 & 13.9 \\
\hline$\alpha$ & 30 & 众 & 21 & きらい & 1 & 5.9 & 26 & 15.9 & & 10.9 & & 6.2 & 12 & 11.7 & 9 & 10.1 & 4 & 6.3 & 82 & 10. I \\
\hline & 3 & & 20 & すき & 1 & 0.8 & & 2.4 & & 2.0 & & 1 & 4 & 3.9 & 2 & 2.2 & 0 & 0 & 16 & 2.0 \\
\hline & & & 21 & きらい & 0 & 0 & 0 & 0 & 1 & 0.6 & & 0.9 & 2 & 1.9 & 5 & 5.6 & 1 & 1.6 & 10 & 1.2 \\
\hline
\end{tabular}

男女とも歯肉の健康者, 歯肉炎执よび歯槽膿漏症をす つもののいずれにおいても，魚類のすきときらいの差は 著しくない.

茂田（1967）23) は魚類のすきなものは，男が女よりも 多く，歯槽膿漏症をむつものでは，すきなむのがきらい なむのより多いといっている。

\section{0 小括}

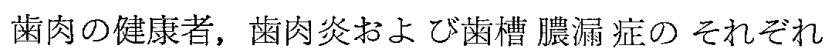
之，食物の嗜好之の関係について，観察をおこなった。 調查を抢てなったすべての男女の各年令に执いて，高温 食物，甘味食物，辛味食物，硬質食物，軟質食物，野菜 類，肉類を好むむのがこれら好まないものよりも多かっ た。いわゆる猫舌に関しては，猫舌でないるのが猫舌の あのより多かった，日常拱取する食物，食品は口腔の健 康状態澋影を与え，上くに歯肉疾患発病の生活因子と なり得ることが少しずつあきらかになりつつある。少年 期加らあ種の温度的条件やある種の食物の影響を長期
にわたって受け続けると，成年期以降に歯周疾患の症状 が，あらわれるであろうということは十分予想されると とである. 本調査の結果から観ると, 高温食物, 軟質食 物，甘味食物を好えで摄取した場合，なんらかの機序に より歯槽膿漏症に罹患する率が高くなるというととがあ きらかとなった。

\section{$11 x^{2}$ 一検定}

歯肉の健康状態を歯肉の健康, 歯肉炎拉よび㐘槽膿漏 症の3者に区分し，各種食物に対する嘹好との関係につ いて年令別に検討した結果, 歯肉の健康状態之食物に対 する搘好との関係には, 年令差がほとんどないととを知 った．それゆえ年令差を考えずに，男女（12〜18才）を それぞれ一群の対象として取扱った。

歯肉疾患と食物との関係をみるために， $x^{2}$ - 検 定に よった，食物などは，高温食物のすき，普通ときらい， 猫舌か否か，甘味食物のすき，きらい，辛味食物のす き，きらい，硬質食物のすき，普通，きらい，軟質食物 
高温食物嗜好之曾肉の健康状態との関係

\begin{tabular}{|c|c|c|c|c|c|c|}
\hline & \multicolumn{3}{|c|}{ 男 } & \multicolumn{3}{|c|}{ 女 } \\
\hline 高温食物 & + & - & 計 & + & - & 計 \\
\hline $\mathrm{C}_{1}$ & 69 & 229 & 298 & 120 & 346 & 466 \\
\hline $\mathrm{C}_{2}$ & 59 & 158 & 217 & 97 & 218 & 315 \\
\hline $\mathrm{C}_{3}$ & 6 & 32 & 38 & 4 & 26 & 30 \\
\hline 計 & 134 & 419 & 553 & 221 & 590 & 811 \\
\hline
\end{tabular}

歯肉 : +・疾病者, 一・健康

高温食物： $\mathrm{C}_{1}$ ・すき, $\mathrm{C}_{2}$ 普通, $\mathrm{Cs}_{3}$ ・きらい
男 3
2.8710
$p$
女 3
6. 2618
$0.50>\mathrm{p}>0.30$
0. $10>\mathrm{p}>0.05$

いわゆる猫舌と歯肉の健康状態の関係

\begin{tabular}{|c|c|c|c|c|c|c|}
\hline \multirow{2}{*}{ いわゆる猫舌 粦 肉 } & \multicolumn{3}{|c|}{ 男 } & \multicolumn{3}{|c|}{ 女 } \\
\hline & + & - & 計 & + & - & 計 \\
\hline $\mathrm{C}_{1}$ & 27 & 90 & 117 & 27 & 80 & 107 \\
\hline $\mathrm{C}_{2}$ & 107 & 329 & 436 & 194 & 510 & 704 \\
\hline 計 & 134 & 419 & 553 & 221 & 590 & 811 \\
\hline
\end{tabular}

歯肉：十・疾病者, 一 健康者

猫舌： $\mathrm{C}_{1}$. 猫舌の者, $\mathrm{C}_{2}$ ・猫舌でない者
男 2
n
$\chi^{2}$
$0.70>\mathbf{p}>0.50$
女 2
0.7387
$0.90>\mathbf{p}>0.80$

甘味食嗜好と歯肉の健康状態との関係

\begin{tabular}{|c|c|c|c|c|c|c|}
\hline 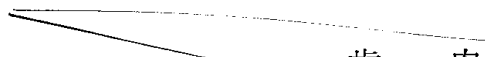 & & 男 & & & 女 & \\
\hline 甘味食物 & + & - & 計 & + & - & 計 \\
\hline $\mathrm{C}_{1}$ & 96 & 338 & 434 & 171 & 434 & 605 \\
\hline $\mathrm{C}_{2}$ & 38 & 81 & 119 & 50 & 156 & 206 \\
\hline 計 & 134 & 419 & 553 & 221 & 590 & 811 \\
\hline
\end{tabular}

歯肉 : +・疾病者, 一・健康者

甘味食物： $\mathrm{C}_{1}$ ・すき, $\mathrm{C}_{2} \cdot$ きらい

$\begin{array}{cccc} & \mathrm{n} & \chi^{\mathbf{2}} & \mathrm{p} \\ \text { 男 } & 2 & 407061 & 0.10>\mathrm{p}>0.05 \\ \text { 女 } & 2 & 1.3353 & 0.70>\mathrm{p}>0.50\end{array}$


食物の嗜好之茵肉の健康に関する疫学的研究

辛味食物嗜好と歯肉の健康状態との関係

\begin{tabular}{|c|c|c|c|c|c|c|}
\hline$x_{n-1}$ & \multicolumn{3}{|c|}{ 男 } & \multicolumn{3}{|c|}{ 女 } \\
\hline 辛味食物 & + & - & 計 & + & - & 計 \\
\hline $\mathrm{C}_{1}$ & 106 & 344 & 450 & 189 & 512 & 701 \\
\hline $\mathrm{C}_{2}$ & 28 & 75 & 103 & 32 & 78 & 110 \\
\hline 計 & 134 & 419 & 553 & 221 & 590 & 811 \\
\hline
\end{tabular}

歯肉 : +・疾病者, 一・健康者

辛味食物： $\mathrm{C}_{1}$ ・すき, $\mathrm{C}_{2}$ ・きらい
男 2
0.5049
$0.80>\mathrm{p}>0.70$
女 2
0.0419
$0.98>p>0.95$

硬質食物嗜好と歯肉の健康状態との関係

\begin{tabular}{|c|c|c|c|c|c|c|}
\hline C齿 & & 男 & & & 女 & \\
\hline 硬質食物 & + & - & 計 & + & - & 計 \\
\hline $\mathrm{C}_{1}$ & 84 & 251 & 335 & 125 & 355 & 480 \\
\hline $\mathrm{C}_{2}$ & 46 & 145 & 191 & 87 & 216 & 303 \\
\hline $\mathrm{C}_{3}$ & 4 & 23 & 27 & 9 & 19 & 28 \\
\hline 計 & 134 & 419 & 553 & 221 & 590 & 811 \\
\hline
\end{tabular}

画肉: +・疾病者, 一・健康者

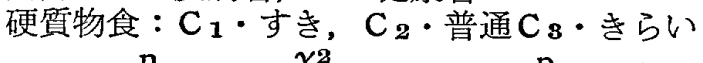
男 3
1. 5848
$0.70>\mathbf{p}>0.50$
女 3
1. 3793
$0.80>p>0.70$

軟質食物喏好之歯肉の健康状態との関係

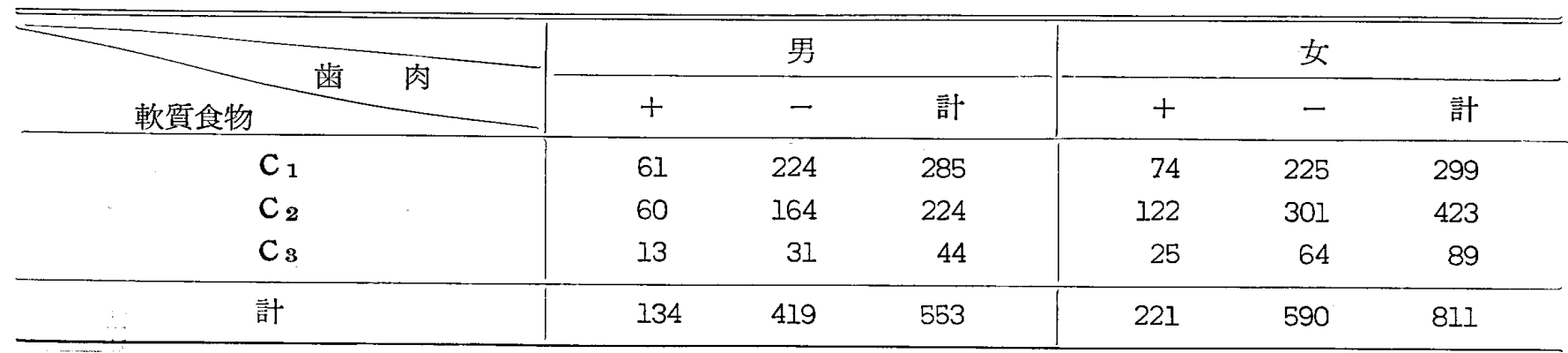

歯肉 $:+\cdot$ 疾病者, 一・健康者

軟質食物： $\mathrm{C}_{1}$ ・すき, $\mathrm{C}_{2} \cdot$ 普通, $\mathrm{C}_{3} \cdot$ きらい
男 3
321.6937
$\mathrm{p}=0$
女 31.4792
$0.70>p>0.50$ 
野菜類食物嗜好と歯肉の健康状態之の関係

\begin{tabular}{|c|c|c|c|c|c|c|}
\hline & \multicolumn{3}{|c|}{ 男 } & \multicolumn{3}{|c|}{ 女 } \\
\hline 野 $_{\text {菜 }}$ 歯肉 & + & - & 計 & + & - & 計 \\
\hline $\mathrm{C}_{1}$ & 102 & 336 & 438 & 185 & 499 & 684 \\
\hline $\mathrm{C}_{2}$ & 32 & 83 & 115 & 36 & 91 & 127 \\
\hline 計 & 134 & 419 & 553 & $22 I$ & 590 & 811 \\
\hline
\end{tabular}

歯肉 : +・疾病者, 一・健康者

野菜： $\mathrm{C}_{1} \cdot$ すき, $\mathrm{C}_{2} \cdot$ きらい

$\begin{array}{rrrc} & \mathrm{n} & \boldsymbol{\chi}^{\mathbf{2}} & \mathrm{p} \\ \text { 男 } & 2 & \mathrm{C.} 8563 & 0.90>\mathrm{p}>0.80 \\ \text { 女 } & 2 & 19.8832 & \mathrm{p} \div 0\end{array}$

肉類食物嗜好と歯肉の健康状態との関係

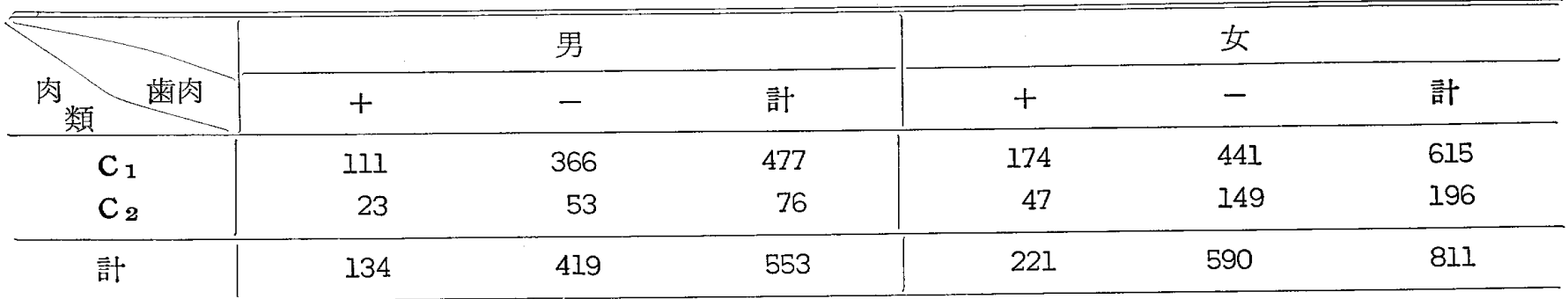

歯肉 : +・疾病者, 一・健康者
肉類 : $\mathrm{C}_{1}$ ・すき, $\mathrm{C}_{2} \cdot$ きらい

$\begin{array}{cccc} & \mathrm{n} & \chi^{\mathbf{2}} & \mathrm{p} \\ \text { 男 } & 2 & 1.6011 & 0.50>\mathrm{p}>0.30 \\ \text { 女 } & 2 & 1.5537 & 0.50>\mathrm{p}>0.30\end{array}$

魚類食物搘好と歯肉の健康状態との関係

\begin{tabular}{|c|c|c|c|c|c|c|}
\hline & & 男 & & & 女 & \\
\hline 魚類 & + & - & 計 & + & - & 計 \\
\hline $\mathrm{C}_{1}$ & 72 & 227 & 299 & 129 & 304 & 433 \\
\hline $\mathrm{C}_{2}$ & 62 & 192 & 254 & 92 & 286 & 378 \\
\hline 計 & 134 & 419 & 553 & 221 & 590 & 811 \\
\hline
\end{tabular}

\begin{tabular}{|c|c|c|c|}
\hline \multicolumn{4}{|c|}{$\begin{array}{l}\text { 歯肉: +・疾病者, 一・健康者 } \\
\text { 魚類 : } \mathrm{C}_{1} \cdot \text { すき } \mathrm{C}_{2} \cdot \text { きらい }\end{array}$} \\
\hline & $\mathrm{n}$ & $\chi^{2}$ & $\mathbf{p}$ \\
\hline 男 & 2 & 0.0063 & $\mathrm{p}=1$ \\
\hline 女 & 2 & 1.8416 & $0.50>$ p $>0.30$ \\
\hline
\end{tabular}

のすき, 普通, きらい. 野菜類のすき, きらい. 肉類の すき, きらい. 魚類のすき, きらいにわけて を扟となた。その結果は表26〜34の上おりである. 両 者の間に関係のあるものは, 女の高温食物, 男の甘味食 物と軟質食物，女の野菜類などである。

〔III]各種因子の百分比成績

食物の高温, いわゆる猫舌, 甘味, 硬質, 軟質, 野菜 類, 肉類のすき, きらいの男女別百分比は, 表35のとお
りである。

1 高温食物きらいなすのは男が7.0\%，女が3.7\%で 男女と屯少ない。

2 いわゆる猫舌

猫舌のあのは男が21.6\%，女が13.2\%で男女ともかな り多く，男が女よりやや多い.

3 甘味食物

すきなものは男が78.0\%，女が74.6\%である。 


\begin{tabular}{|c|c|c|c|c|c|c|c|c|c|c|c|}
\hline 食 & 物 & な & ど & & & & & & & 男 & 女 \\
\hline No. & & 種 & & 類 & 区 & & 別 & 符 & 号 & $(\%)$ & $(\%)$ \\
\hline 1 & & $\begin{array}{l}\text { 高 } \\
\text { 食 }\end{array}$ & 温 & $\begin{array}{l}\text { な } \\
\text { 物 }\end{array}$ & $\begin{array}{l}\text { す } \\
\text { 普 } \\
\text { き }\end{array}$ & b & $\begin{array}{l}\text { き } \\
\text { 通 } \\
\text { い }\end{array}$ & & $\begin{array}{l}\mathrm{C}_{1} \\
\mathrm{C}_{2} \\
\mathrm{C}_{3}\end{array}$ & $\begin{array}{r}53.5 \\
39.0 \\
7.0\end{array}$ & $\begin{array}{r}57.5 \\
38.8 \\
3.7\end{array}$ \\
\hline 2 & & 猫 & & 舌 & $\begin{array}{l}\text { は } \\
\text { い }\end{array}$ & $w$ & $\begin{array}{l}w \\
\text { え }\end{array}$ & & $\begin{array}{l}\mathrm{C}_{1} \\
\mathrm{C}_{2}\end{array}$ & $\begin{array}{l}21.6 \\
78.4\end{array}$ & $\begin{array}{l}13.2 \\
86.8\end{array}$ \\
\hline 3 & & $\begin{array}{l}甘 \\
\text { 食 } \\
\end{array}$ & & $\begin{array}{l}\text { 味 } \\
\text { 物 } \\
\end{array}$ & $\begin{array}{l}\text { す } \\
\text { き }\end{array}$ & 5 & $\begin{array}{l}\text { き } \\
\text { い }\end{array}$ & & $\begin{array}{l}\mathrm{C}_{1} \\
\mathrm{C}_{2} \\
\end{array}$ & $\begin{array}{l}78.0 \\
22.0\end{array}$ & $\begin{array}{l}74.6 \\
25.4\end{array}$ \\
\hline 4 & & $\begin{array}{l}\text { 辛 } \\
\text { 食 }\end{array}$ & & $\begin{array}{l}\text { 味 } \\
\text { 物 }\end{array}$ & $\begin{array}{l}\text { す } \\
\text { き }\end{array}$ & 5 & $\begin{array}{l}\text { き } \\
\text { い } \\
\end{array}$ & & $\begin{array}{l}\mathrm{C}_{1} \\
\mathrm{C}_{2}\end{array}$ & $\begin{array}{l}80.9 \\
19.1\end{array}$ & $\begin{array}{l}86.4 \\
13.6\end{array}$ \\
\hline 5 & & $\begin{array}{l}\text { 硬 } \\
\text { 食 }\end{array}$ & & $\begin{array}{l}W \\
\text { 物 }\end{array}$ & $\begin{array}{l}\text { す } \\
\text { 普 } \\
\text { き }\end{array}$ & 5 & $\begin{array}{l}\text { き } \\
\text { 通 } \\
\text { い }\end{array}$ & & $\begin{array}{l}\mathrm{C}_{1} \\
\mathrm{C}_{2} \\
\mathrm{C}_{3}\end{array}$ & $\begin{array}{r}60.2 \\
34.3 \\
5.5\end{array}$ & $\begin{array}{r}59.2 \\
37.4 \\
3.4 \\
\end{array}$ \\
\hline 6 & & $\begin{array}{l}\text { 軟 } \\
\text { 食 }\end{array}$ & & $\begin{array}{l}\text { W } \\
\text { 物 }\end{array}$ & $\begin{array}{l}\text { す } \\
\text { 普 } \\
\text { き }\end{array}$ & 5 & $\begin{array}{l}\text { き } \\
\text { 通 } \\
\text { い }\end{array}$ & & $\begin{array}{l}\mathrm{C}_{1} \\
\mathrm{C}_{2} \\
\mathrm{C}_{3}\end{array}$ & $\begin{array}{r}51.2 \\
40.3 \\
8.5\end{array}$ & $\begin{array}{l}36.9 \\
52.2 \\
10.9\end{array}$ \\
\hline 7 & & 野 & & 菜 & $\begin{array}{l}\text { す } \\
\text { き }\end{array}$ & 5 & $\begin{array}{l}\text { き } \\
\text { い }\end{array}$ & & $\begin{array}{l}\mathrm{C}_{1} \\
\mathrm{C}_{2}\end{array}$ & $\begin{array}{l}78.8 \\
21.2\end{array}$ & $\begin{array}{l}84.3 \\
15.7\end{array}$ \\
\hline 8 & & 肉 & & 類 & $\begin{array}{l}\text { す } \\
\text { き }\end{array}$ & 5 & $\begin{array}{l}き \\
\text { } \\
\end{array}$ & & $\begin{array}{l}\mathrm{C}_{1} \\
\mathrm{C}_{2}\end{array}$ & $\begin{array}{l}85.7 \\
14.3 \\
\end{array}$ & $\begin{array}{l}75.8 \\
24.2 \\
\end{array}$ \\
\hline 9 & & 魚 & & 類 & $\begin{array}{l}\text { す } \\
\text { き }\end{array}$ & 5 & $\begin{array}{l}\text { き } \\
\text { い } \\
\end{array}$ & & $\begin{array}{l}\mathrm{C}_{1} \\
\mathrm{C}_{2}\end{array}$ & $\begin{array}{l}53.7 \\
46.3 \\
\end{array}$ & $\begin{array}{l}53.4 \\
46.6 \\
\end{array}$ \\
\hline
\end{tabular}

\section{4 辛味食物}

すきなむのは男が80.9\%，女が86.4\%である.

5 硬質食物

きらいなものは男が5.5\%，女が3.4\%である。

6 軟質食物

きらいなあのは男が8.3\%，女が10.9\%である.

7 野菜類食物

すきなむのは男が78.8\%，女が84.3\%でかなり多い.

8 肉類食物

すきなものは男が85.7\%，女が75.8\% でわずかに多 い.

\section{9 魚類}

すきはものは男が53.7\%，女が53.4\%である，男女之 あ肉類に比べて少ない.

〔IV〕歯の刷掃についての調查成績

II日に打りる蒾みがきの時期
いつ歯をみがくかは表36，37の上おりである．男女と あ朝食前がもっとも多く, ついで就寝前, 朝食後の順之 なっている.

川島（1949）28)は学童の口腔の清掃度之清潔度との関 係について発表したなかで，朝夕それぞれI回みがくも のが約54\%であり，清掃度に対する清潔度の関係は，や や比例的であるが, 清潔度に対するう菌数の関係はあき らかでなかったと述べている．金光（1959）29)はゴム工 場女子従業員の口臇衛生状態を調査し, 2, 572人中 1 日 2 回歯をみがくあのは80\%で，とくに朝が多かったと発表 している. 木村他 (1969) 30)は歯刷子使用状況を調査し たなかで，刷掃は朝食前が62.9\%，毎食後あるいは毎食 後と就寝前が5.3\%で，きわぬて少なかったと述へててい る.また木下他（1963）5）は1日の崡みがき回数は1回 が41.4\%，2 回が49.9\%であったと述べている。これら の成績之著者のそれ之は大体において類似している。適 
男：1日における歯みがきの時期

\begin{tabular}{|c|c|c|c|c|c|c|c|c|c|c|}
\hline & 年令 & & 12 & 13 & 14 & 15 & 16 & 17 & 18 & $12 \sim 18$ \\
\hline No. & 使用時間 & 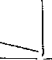 & 61 & 203 & 232 & 54 & 440 & 436 & 34 & 1. 460 \\
\hline 19 & 朝 食 前 & & $\begin{array}{r}36 \\
62.1 \\
\end{array}$ & $\begin{array}{r}108 \\
55.7 \\
\end{array}$ & $\begin{array}{r}128 \\
56.3 \\
\end{array}$ & $\begin{array}{r}31 \\
58.5 \\
\end{array}$ & $\begin{array}{r}223 \\
51.1 \\
\end{array}$ & $\begin{array}{r}241 \\
55.9 \\
\end{array}$ & $\begin{array}{r}19 \\
56.0 \\
\end{array}$ & $\begin{array}{r}786 \\
54.8 \\
\end{array}$ \\
\hline 20 & 朝 食 後 & $\left|\begin{array}{l}\mathbf{N} \\
0\end{array}\right|$ & $\begin{array}{r}4 \\
6.8 \\
\end{array}$ & $\begin{array}{r}15 \\
7.7 \\
\end{array}$ & $\begin{array}{r}17 \\
7.5 \\
\end{array}$ & $\begin{array}{r}4 \\
7.6 \\
\end{array}$ & $\begin{array}{r}38 \\
8.7 \\
\end{array}$ & $\begin{array}{r}41 \\
9.5 \\
\end{array}$ & & $\begin{array}{l}119 \\
8.3 \\
\end{array}$ \\
\hline 23 & 夕 食 前 & & & & & & $\begin{array}{r}2 \\
0.5 \\
\end{array}$ & & & $\begin{array}{l}2 \\
0.1\end{array}$ \\
\hline 24 & 夕 食 後 & $\left|\begin{array}{l}\mathbf{N} \\
\%\end{array}\right|$ & $\begin{array}{r}3 \\
5.2 \\
\end{array}$ & $\begin{array}{r}4 \\
2.1 \\
\end{array}$ & $\begin{array}{r}7 \\
3.1 \\
\end{array}$ & 1.8 & $\begin{array}{r}14 \\
3.2 \\
\end{array}$ & $\begin{array}{r}9 \\
2.1 \\
\end{array}$ & $\begin{array}{r}1 \\
2.9 \\
\end{array}$ & $\begin{array}{r}39 \\
2.7\end{array}$ \\
\hline 25 & 就 寝 前 & $\left|\begin{array}{l}\mathrm{N} \\
\%\end{array}\right|$ & $\begin{array}{r}7 \\
12.1\end{array}$ & $\begin{array}{r}31 \\
16.0\end{array}$ & $\begin{array}{r}30 \\
13.2 \\
\end{array}$ & $\begin{array}{r}6 \\
11.3 \\
\end{array}$ & $\begin{array}{r}73 \\
16.7 \\
\end{array}$ & $\begin{array}{r}61 \\
14.2 \\
\end{array}$ & $\begin{array}{r}5 \\
14.7 \\
\end{array}$ & $\begin{array}{r}213 \\
14.9 \\
\end{array}$ \\
\hline $\begin{array}{l}19 \\
20\end{array}$ & 朝 食 前 後 & & & & $\begin{array}{r}2 \\
0.8 \\
\end{array}$ & & $0 . \frac{1}{2}$ & & & $\begin{array}{r}3 \\
0.2 \\
\end{array}$ \\
\hline $\begin{array}{l}19 \\
24 \\
\end{array}$ & $\begin{array}{lll} & \text { 食 } & \text { 前 } \\
\text { 多 } & \text { 食後 } \\
\end{array}$ & $\left|\begin{array}{l}\mathbf{N} \\
\%\end{array}\right|$ & $\begin{array}{r}3 \\
5.2 \\
\end{array}$ & $\begin{array}{r}11 \\
5.7 \\
\end{array}$ & $\begin{array}{r}8 \\
3.6 \\
\end{array}$ & $\begin{array}{r}2 \\
3.8 \\
\end{array}$ & $\begin{array}{r}9 \\
2.1 \\
\end{array}$ & $\begin{array}{r}9 \\
2.1 \\
\end{array}$ & & $\begin{array}{r}42 \\
2.9 \\
\end{array}$ \\
\hline $\begin{array}{l}19 \\
25\end{array}$ & $\begin{array}{lll}\text { 朝 } & \text { 食 } & \text { 前 } \\
\text { 前 }\end{array}$ & $\mid \begin{array}{l}\mathbf{N} \\
\%\end{array}$ & $\begin{array}{r}3 \\
5.2 \\
\end{array}$ & $\begin{array}{r}22 \\
11.3 \\
\end{array}$ & $\begin{array}{r}26 \\
11.5 \\
\end{array}$ & $\begin{array}{r}7 \\
13.2 \\
\end{array}$ & $\begin{array}{r}61 \\
13.9 \\
\end{array}$ & $\begin{array}{r}45 \\
10.4 \\
\end{array}$ & $\begin{array}{r}7 \\
20.6 \\
\end{array}$ & $\begin{array}{r}171 \\
11.9\end{array}$ \\
\hline $\begin{array}{r}20 \\
24 \\
\end{array}$ & $\begin{array}{lll}\text { 朝 } & \text { 食 } & \text { 後 } \\
\end{array}$ & $|\mathbf{N}|$ & $\begin{array}{r}2 \\
3.4 \\
\end{array}$ & $\begin{array}{r}1 \\
0.5 \\
\end{array}$ & $\begin{array}{r}3 \\
1.4 \\
\end{array}$ & & $\begin{array}{r}4 \\
0.9 \\
\end{array}$ & $\begin{array}{r}2 \\
0.5 \\
\end{array}$ & $\begin{array}{r}1 \\
2.9 \\
\end{array}$ & $\begin{array}{l}13 \\
0.9 \\
\end{array}$ \\
\hline $\begin{array}{l}20 \\
25 \\
21\end{array}$ & 朝食後就寝前 & & & $\begin{array}{r}2 \\
1.0 \\
\end{array}$ & $\begin{array}{r}6 \\
2.6 \\
\end{array}$ & $\begin{array}{r}2 \\
3.8 \\
\end{array}$ & $\begin{array}{r}9 \\
2.1 \\
\end{array}$ & $\begin{array}{r}20 \\
4.7 \\
\end{array}$ & $2 . \frac{1}{9}$ & $\begin{array}{r}40 \\
2.8 \\
\end{array}$ \\
\hline $\begin{array}{r}24 \\
25 \\
\end{array}$ & 夕食後水る前 & & & & & & & 0.2 & & 0.1 \\
\hline $\begin{array}{l}19 \\
20 \\
25 \\
\end{array}$ & 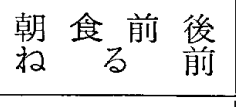 & & & & & & $0 . \frac{1}{2}$ & & & 0.1 \\
\hline $\begin{array}{l}19 \\
23 \\
25 \\
\end{array}$ & $\begin{array}{l}\text { 朝食前夕食前 } \\
\text { る }\end{array}$ & & & & & & $0 . \frac{1}{2}$ & & & 0.1 \\
\hline $\begin{array}{l}20 \\
24 \\
25 \\
\end{array}$ & $\begin{array}{l}\text { 朝食後夕食後 } \\
\text { 前 }\end{array}$ & & & & & & 0.1 & 0.1 & & $\begin{array}{r}2 \\
0.1 \\
\end{array}$ \\
\hline $\begin{array}{l}19 \\
24 \\
25 \\
\end{array}$ & $\begin{array}{l}\text { 朝食前夕食後 } \\
\text { 前 }\end{array}$ & & & & & & & $0 . \frac{1}{2}$ & & 0.1 \\
\hline & 回 答 & $\mathbf{N}$ & 3 & 9 & 5 & 1 & 3 & 5 & & 26 \\
\hline
\end{tabular}

\section{表37}

女：工日における䨑みがきの時期

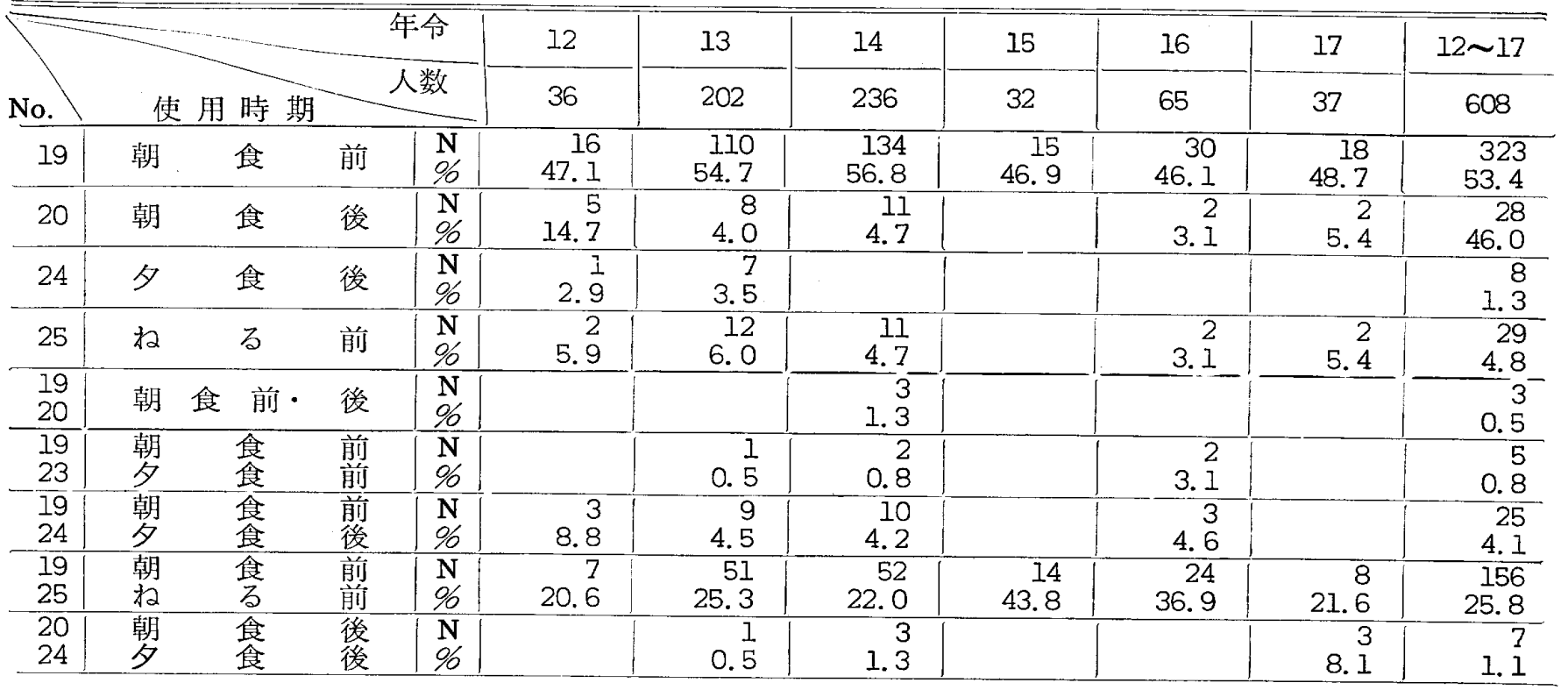




\begin{tabular}{|c|c|c|c|c|c|c|c|c|c|c|}
\hline $\begin{array}{l}20 \\
25\end{array}$ & $\begin{array}{l}\text { 朝 } \\
ね \\
\end{array}$ & $\begin{array}{l}\text { 食 } \\
\text { - }\end{array}$ & $\begin{array}{l}\mathbf{N} \\
\phi 6\end{array}$ & & $\begin{array}{r}2 \\
1.0 \\
\end{array}$ & $\begin{array}{r}9 \\
3.8 \\
\end{array}$ & $\begin{array}{r}3 \\
9.3\end{array}$ & $\begin{array}{r}2 \\
3.1 \\
\end{array}$ & $\begin{array}{r}4 \\
10.8 \\
\end{array}$ & $\begin{array}{r}20 \\
3.3 \\
\end{array}$ \\
\hline $\begin{array}{l}19 \\
23 \\
25\end{array}$ & $\begin{array}{l}\text { 朝食前 } \\
\text { 和 }\end{array}$ & $\dot{z}$ 夕食前 & $\begin{array}{l}\mathrm{N} \\
\%\end{array}$ & & & 0. $\frac{1}{4}$ & & & & $0 . \frac{1}{3}$ \\
\hline & 未 & 答 & $\mathrm{N}$ & 2 & $I$ & & & & & 3 \\
\hline
\end{tabular}

I日に打ける蒾みがきの時期

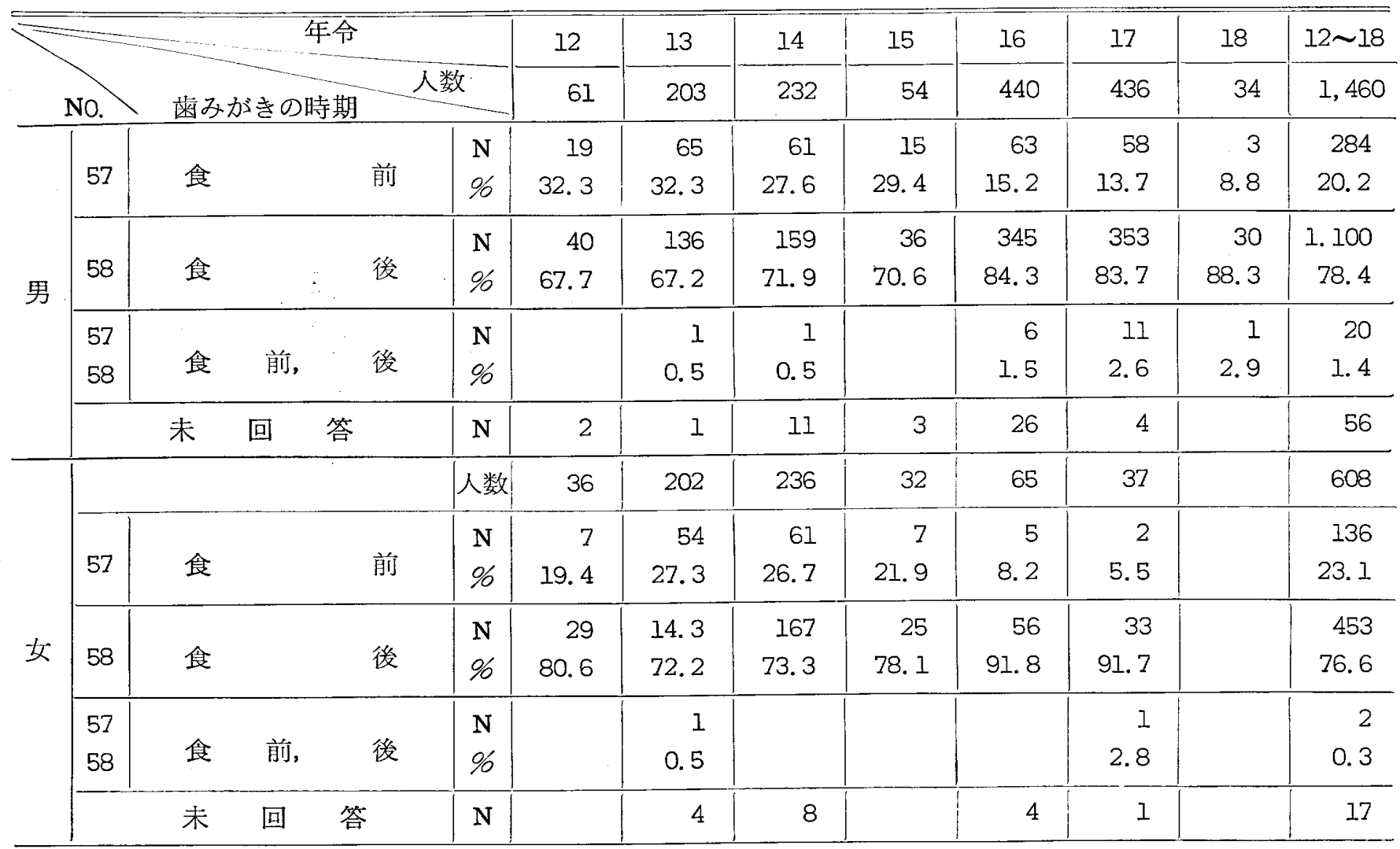

正な霜みがきの時期については表38のとおりである．男 女とも食後がよいと思うあのが，食前がよいと思うあの よりも著しく多く，適正な時期は把握している。

\section{1 回の歯みがきに要する時間}

1 回の歯みがきに要する時間は，表39，400とおりで ある。男では 3 分があっと屯多く，ついで 2 分，1分， 5 分の順に少なくなっており，女では 2 分があっとも多 く，ついで3分，1分 5 分の順に少なくなってい る. 年令別平均時間は, 男では 22 才が平均3.0 分で. 增 令につれて減少し，18才では平均1.9 分である，女は 12 才が平均 2.6 分，17才が2.0分で，増令につれてわずかに 減少し，18才では平均1.9分である．女は12才が平均 2.6 分, 17才が2.0分で, 增令につ㣗てわずかに減少してい る. 男は12〜18才の平均が2.5分, 女は $12 \sim 17$ 才の平均 が2.6分である.

木下他（1963）5）は1回の刷掃時間は，2 分が28.3\%
と発表しているが，乙れは著者の成績と大体において類 似している。

\section{1日に打歯みがきの回数}

1日の雨をみがく回数は，表41のとおりである．曾を 1回あみがかないあのが12才に23.4\%であっと屯多く， 増令につ机て減少し，18才では2.9\%である，12〜18才 での平均は4.5\%である，女はほとんど歯をみがいてい る。男女いずれにおいてす，1日に1回だけみがくあの があっとも多く，ついで2回，3回の順に少なくなって いる．女の方が一般に男より歯をみがく回数が多い.

岡本他（1959）31は1日 2 回朝と晚にみがくのがよい とし, 晚は夕食直後であ就寝前でもよいと述べている.

木下他 (1963) 5) は 1 日の歯みがき回数は 2 回が47.9 \%,1回が41.4\%,3回が6.5\%,4 回が1.4\%であった と述べている．Fosdick 他（1964）32)は12才の児童の I 日の蒾みがき回数について，2回は女が $39.0 \%$ ，男が 
男：工回の歯みがきに要する時闒（分）

\begin{tabular}{|c|c|c|c|c|c|c|c|c|c|c|}
\hline \multirow{2}{*}{\multicolumn{3}{|c|}{ No. 時間(分) }} & 12 & 13 & 14 & 15 & 16 & 17 & 18 & $12 \sim 18$ \\
\hline & & & 61 & 203 & 232 & 54 & 440 & 436 & 34 & 1,460 \\
\hline \multirow{23}{*}{27} & \multirow{2}{*}{0.5} & $\mathrm{~N}$ & & 6 & 4 & 1 & 20 & 25 & 2 & 58 \\
\hline & & $\%$ & & 3.1 & 1. 7 & 2.0 & 4.8 & 5.8 & 5.9 & 4. 1 \\
\hline & \multirow[b]{2}{*}{1} & $\mathrm{~N}$ & 11 & 30 & 51 & 16 & 110 & 129 & 12 & 359 \\
\hline & & $\%$ & 18.3 & 15.3 & 22.3 & 32.0 & 26.1 & 30.2 & 35.3 & 25.3 \\
\hline & \multirow{2}{*}{2} & $\mathrm{~N}$ & 13 & 55 & 71 & 10 & 139 & 116 & 12 & 416 \\
\hline & & $\%$ & 21.7 & 28.1 & 31.0 & 20.0 & 32.9 & 27.2 & 35.3 & 29.3 \\
\hline & \multirow{2}{*}{3} & $\mathrm{~N}$ & 18 & 60 & 57 & 16 & 92 & 106 & 6 & 355 \\
\hline & & $\%$ & 30.0 & 30.6 & 24.6 & 32.0 & 21.8 & 24.8 & 17.7 & 25.0 \\
\hline & \multirow{2}{*}{4} & $\mathrm{~N}$ & & 11 & 11 & 1 & 11 & .14 & 1 & 49 \\
\hline & & $\%$ & & 5.6 & 4.8 & 2.0 & 2.6 & 3.4 & 2.9 & 3.5 \\
\hline & \multirow{2}{*}{5} & $\mathrm{~N}$ & 18 & 33 & 30 & 3 & 42 & 36 & 1 & 163 \\
\hline & & $\%$ & 30.0 & 16.8 & 13. 1 & 6.0 & 9.9 & 8.4 & 2.9 & 11.5 \\
\hline & \multirow{2}{*}{6} & $\mathrm{~N}$ & & & 2 & 1 & 2 & & & 5 \\
\hline & & $\%$ & & & 0.9 & 2.0 & 0.5 & & & 0.4 \\
\hline & \multirow{2}{*}{7} & $\mathrm{~N}$ & & & 1 & & 2 & & & 3 \\
\hline & & $\%$ & & & 0.4 & & 0.5 & & & 0.2 \\
\hline & \multirow[b]{2}{*}{8} & $\mathrm{~N}$ & & & 2 & & 1 & & & 3 \\
\hline & & $\%$ & & & 0.9 & & 0.2 & & & 0.2 \\
\hline & \multirow{2}{*}{9} & $\mathrm{~N}$ & & & & & & & & \\
\hline & & $\%$ & & & & & & & & \\
\hline & \multirow{2}{*}{10} & $\mathrm{~N}$ & & 1 & & 2 & 3 & 1 & & 7 \\
\hline & & $\%$ & & 0.5 & & 4.0 & 0.7 & 0.2 & & 0.5 \\
\hline & 末 & 回 答 & 1 & 7 & 3 & 4 & 18 & 9 & & 42 \\
\hline & $\overline{\mathrm{x}}$ & （分） & 3. 02 & 2.75 & 2.59 & 2.52 & 2. 37 & 2.18 & 1.85 & 2.45 \\
\hline & $x$ & (II) & 1. 48 & 1. 45 & 1.56 & 1.99 & 1.52 & 1.34 & 1.08 & 1.50 \\
\hline
\end{tabular}

11.3\%,1回は女が35.0\%，男が39.1\%，上きどきみが くものは女が26.0\%，男が46.6\%であると報告してい る。厚生省 (1967) 33)によれば，毎日みがくものは6〜 9才では男が21.7\%，女が30.8\%；10１4才では男が 40.7\%, 女が39.2\%；15１9才では男が78.1\%，女が 92.4\%；6〜19才では男が55.7\%, 女が $67.6 \%$, 平均 62.4\%であり，みがかないものは，6〜9才では男が 33.6\%，女が22.1\%；10〜14才では男が 15.5\%，女が 7.5\%；15〜19才では男が3.5\%，女が0.6\%である.

4 歯冠唇側の刷掃方法

粜冠唇側の刷掃方法は, 表42のとおりである，男女と
も上下運動によるものがもっとも多く，ついで上下と水 平の運動によるもの，水平運動によるものの順に少なく なっている。

Robinson（1959）34)は，450人中，廻転法によるあの が37\%，垂直法によるものが $24 \% ，$ 水平法によるものが 35\%であったと述べている. 石川他（1966）35)は凷刷子 の操作法のちがいによる圧力の相違について調へ，迴転 法, Stillman 法, 执よび Charter 法の場合, いずれあ 刷毛部全域に対する力として男女とも $900 \sim 1,150 \mathrm{~g}$, 電 動蒾刷子では300〜 400 g, 重直法, 描円法の場合, およ び咬合面の刷掃の場合はいずれも150〜270gであると述 
表 40

女：工回の歯みがきに要する時間(分)

\begin{tabular}{|c|c|c|c|c|c|c|c|c|c|}
\hline & & 年令 & 12 & 13 & 14 & 15 & 16 & 17 & $12 \sim 17$ \\
\hline No. & & 人数 & 36 & 202 & 236 & 32 & 65 & 37 & 608 \\
\hline & & $\mathbf{N}$ & & 1 & 6 & & 3 & 1 & 11 \\
\hline & 0.5 & $\%$ & & 0.5 & 2.6 & & 4.7 & 2.8 & 1.8 \\
\hline & & $\mathrm{N}$ & 5 & 23 & 38 & 7 & 18 & 10 & 101 \\
\hline & 1 & $\%$ & 14.3 & 11.5 & 16.3 & 21.9 & 28.1 & 28.7 & 16.9 \\
\hline & 0 & $\mathbf{N}$ & 14 & 74 & 81 & 9 & 19 & 14 & 211 \\
\hline & 2 & $\%$ & 40.0 & 37.2 & 34.8 & 28.1 & 29.7 & 40.0 & 35.3 \\
\hline & & $\mathrm{N}$ & 9 & 66 & 69 & 7 & 19 & 8 & 178 \\
\hline & 3 & $\%$ & 25.7 & 33.2 & 29.6 & 21.9 & 29.7 & 22.9 & 29.8 \\
\hline & & $\mathrm{N}$ & 4 & 8 & 4 & 2 & & 1 & 19 \\
\hline & 4 & $\%$ & 11.4 & 4.0 & 1.7 & 6.2 & & 2.8 & 3.2 \\
\hline & & $\mathrm{N}$ & 3 & 26 & 35 & 6 & 5 & 1 & 76 \\
\hline & 5 & $\%$ & 8.6 & 13. 1 & 15.0 & 18.7 & 7.8 & 2.8 & 12.7 \\
\hline & & $\mathrm{N}$ & & $I$ & & $I$ & & & 2 \\
\hline & $b$ & $\%$ & & 0.5 & & 3. 2 & & & 0.3 \\
\hline & 末 & 回 答 & 1 & 3 & 3 & & 1 & 2 & 10 \\
\hline & $\overline{\mathbf{X}}$ & (分) & 2.60 & 2.70 & 2. 57 & 2.81 & 1.85 & 2. 03 & 2.55 \\
\hline & Sx & (分) & 1. 27 & 1. 18 & 1. 29 & 1.51 & 1. 21 & 1.01 & 1.25 \\
\hline
\end{tabular}

表41

エ日に打ける崡みがきの回数

\begin{tabular}{|c|c|c|c|c|c|c|c|c|c|c|c|}
\hline \multicolumn{4}{|c|}{ 年令 } & 12 & 13 & 14 & 15 & 16 & 17 & 18 & $12 \sim 18$ \\
\hline & & & & 61 & 203 & 232 & 54 & 440 & 436 & 34 & 1,460 \\
\hline \multirow{9}{*}{ 男 } & \multirow{2}{*}{15} & \multirow{2}{*}{0} & $\mathrm{~N}$ & 14 & 17 & 8 & 1 & 15 & 9 & 1 & 65 \\
\hline & & & $\%$ & 23.4 & 8.4 & 3.5 & 1.9 & 3. 4 & 2.1 & 2.9 & 4.5 \\
\hline & \multirow{2}{*}{16} & \multirow{2}{*}{1} & $\mathrm{~N}$ & 37 & 149 & 178 & 39 & 337 & 343 & 24 & 1,107 \\
\hline & & & $\%$ & 61.6 & 73.8 & 76.7 & 75.0 & 76.8 & 79. 3 & 70.6 & 76.3 \\
\hline & \multirow{2}{*}{17} & \multirow{2}{*}{2} & $\mathrm{~N}$ & 9 & 36 & 46 & 12 & 84 & 78 & 9 & 274 \\
\hline & & & $\%$ & 15.0 & 17.8 & 19.8 & 23.1 & 19.1 & 18.1 & 26.5 & 18.8 \\
\hline & \multirow{2}{*}{18} & \multirow{2}{*}{3} & $\mathrm{~N}$ & & & & & 3 & 2 & & 5 \\
\hline & & & $\%$ & & & & & 0.7 & 0.5 & & 0.4 \\
\hline & \multicolumn{2}{|c|}{ 未回答 } & $\mathrm{N}$ & 1 & $I$ & & 2 & 1 & 4 & & 9 \\
\hline
\end{tabular}




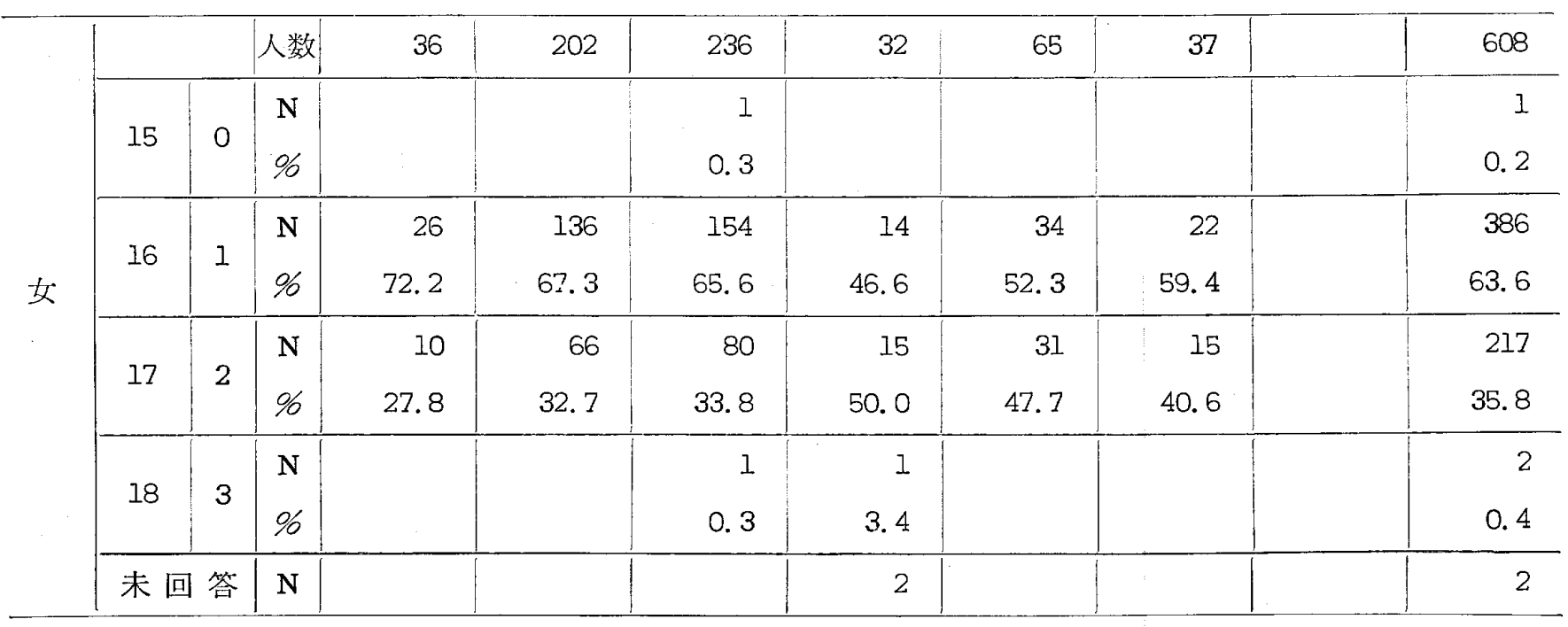

べている．木村他（1969）30)は横みがき法が60.2\%，横 みがきと縦みがきを組合せた方法が14.6\%であった発之 表している. 今西 (1969）36)はう蝕好発期の比年令に適 応した刷掃法を適切に指導するならば，功りり有効な刷 掃効果を期待できるといっている．上にかく合理的なブ ラッシングによる機械的な剌激を歯肉に与えた場合，そ の直後より歯肉毛細血管の著明な拡張が認められ，歯肉 ポケットからの渗出液の量が一過性に増すといわ机る が，これはブラッシングの歯肉の血液循環を促進するた めのあのと思われる. と机よって歯肉の充血, うっ血, 腫脹, 浮腫などの炎症性変化が改善されることになる。

\section{5 歯冠舌側の刷掃力法}

歯冠舌侧面をみがくあのは，表43のと㧍りである．舌 側面をみがくあのは男が78.3\% (12〜18才)，女が83.1 $\%$ (12 17才) で, 男女間の差も增令的差もともに著し くない.

柬冠部舌面の刷掃の方法は，表44のと扔りである，男 女とも水平がもっとも多く，ついで上下の順となってい る.

\section{1本の歯刷子の使用期間}

工本の歯刷子の使用期間は，表45，46 のとおりであ る. 男女と屯 4 力月があっとも多く，ついで3カ月， 6

表42 歯冠唇 側の刷掃方法

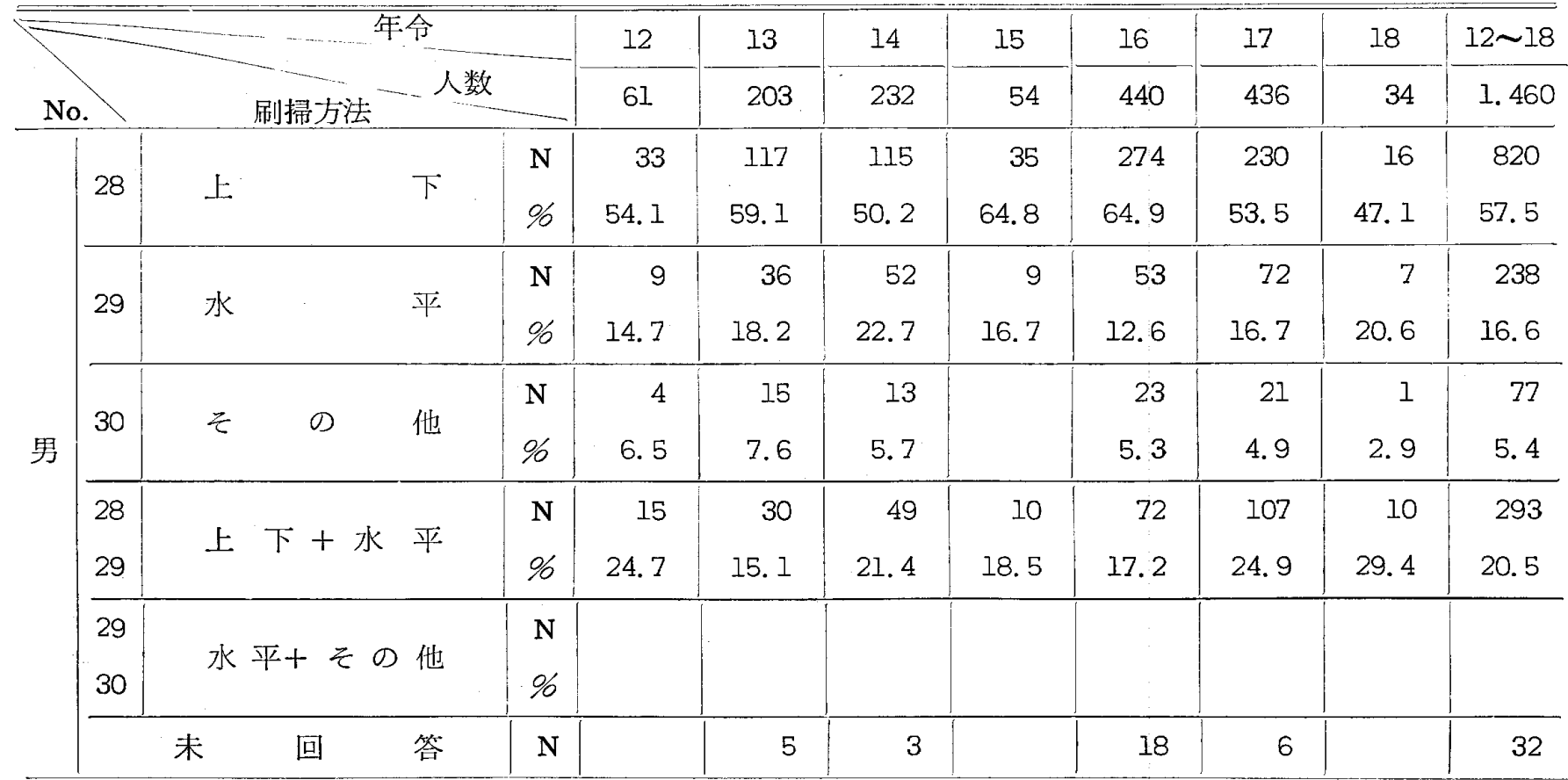




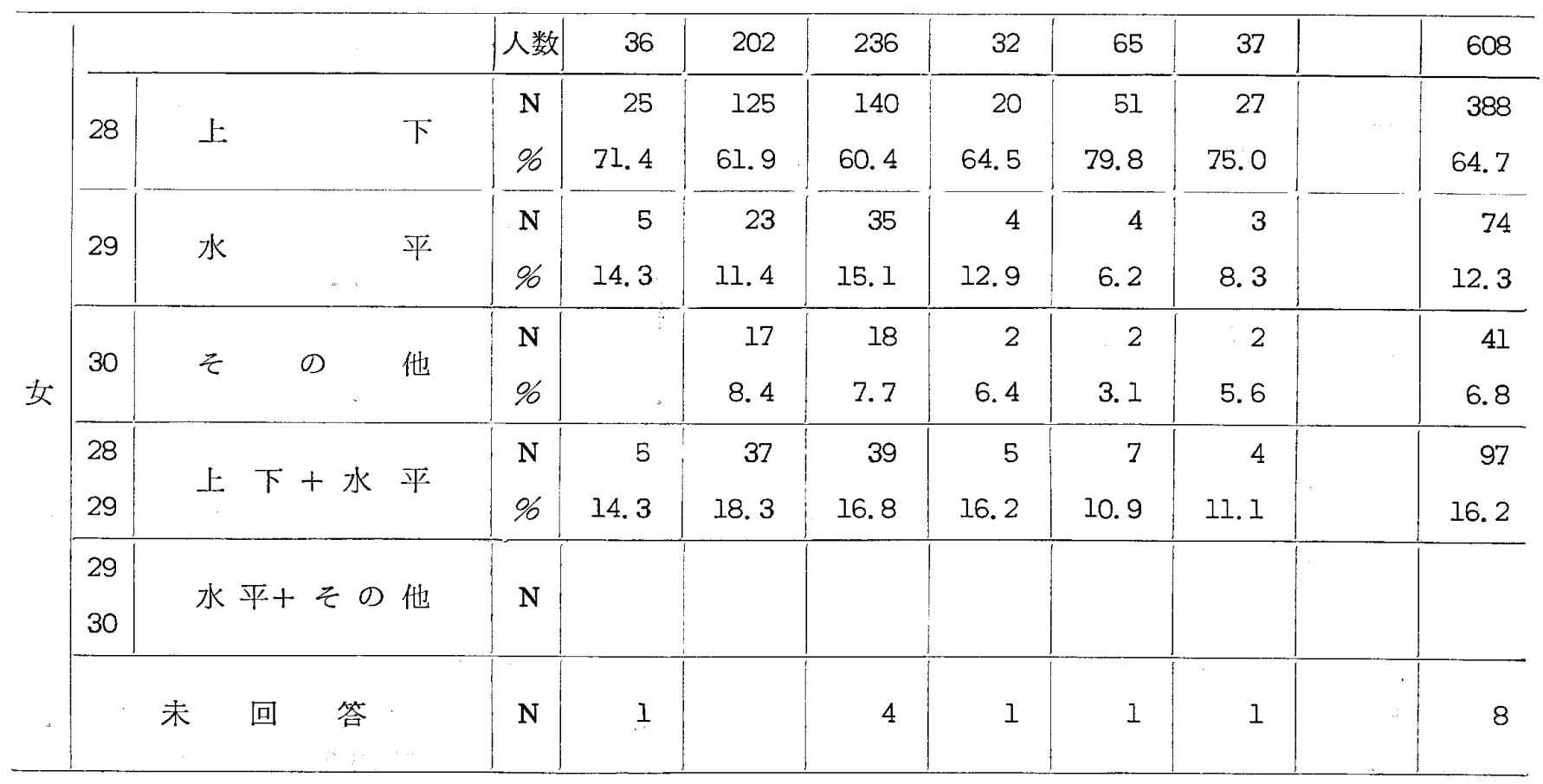

表 43

歯冠舌側の刷掃方法

\begin{tabular}{|c|c|c|c|c|c|c|c|c|c|c|c|c|c|c|}
\hline \multirow{2}{*}{\multicolumn{2}{|c|}{ No. }} & \multicolumn{5}{|c|}{ 年令 } & 12 & 13 & 14 & 15 & 16 & 17 & 18 & $12 \sim 18$ \\
\hline & & 壬 & 側 & 刷 & \multicolumn{2}{|c|}{ 人掃 人数 } & 61 & 203 & 232 & 54 & 440 & 436 & 34 & 1,460 \\
\hline \multirow{5}{*}{ 男 } & \multirow{2}{*}{31.} & \multirow{2}{*}{ 磨 } & & \multirow{2}{*}{\multicolumn{2}{|c|}{$<$}} & $\mathrm{N}$ & 48 & 166 & 178 & 40 & 331 & 339 & 29 & 1,131 \\
\hline & & & & & & 96 & 81.4 & 83.0 & 77.3 & 74.1 & 76.4 & 77.9 & 85.2 & 78.3 \\
\hline & \multirow{2}{*}{32} & \multirow{2}{*}{ 磨 } & \multirow{2}{*}{ 加 } & \multirow{2}{*}{ な } & \multirow{2}{*}{ w } & $\mathrm{N}$ & 11 & 34 & 52 & 14 & 102 & 92 & 5 & 310 \\
\hline & & & & & & 96 & 18.6 & 17.0 & 22.7 & 25. 9 & 23.6 & 22.1 & 14.8 & 21.7 \\
\hline & & 未 & 回 & 答 & & $\mathrm{N}$ & 2 & 3 & 2 & & 7 & 5 & & 19 \\
\hline \multirow{6}{*}{ 女 } & & & & & & 人数 & 36 & 202 & 236 & 32 & 65 & 37 & & 608 \\
\hline & & \multirow{2}{*}{ 磨 } & & \multirow{2}{*}{\multicolumn{2}{|c|}{$<$}} & $\mathrm{N}$ & 30 & 168 & 187 & 27 & 57 & 34 & & 503 \\
\hline & & & & & & $\%$ & 83. 3 & 83.6 & 79.9 & 84.4 & 87.7 & 91.9 & & 83.1 \\
\hline & \multirow{2}{*}{32} & & \multirow{2}{*}{ 加 } & \multirow{2}{*}{ な } & \multirow{2}{*}{$w$} & $\mathrm{~N}$ & 6 & 33 & 47 & 5 & 8 & 3 & & 102 \\
\hline & & & & & & 96 & 16.7 & 16.4 & 20.1 & 15.6 & 12.3 & 8.1 & & 16.9 \\
\hline & & 未 & 回 & 答 & & $\mathrm{N}$ & & 1 & 2 & & & & & 3 \\
\hline
\end{tabular}


歯冠舌側の刷掃方法

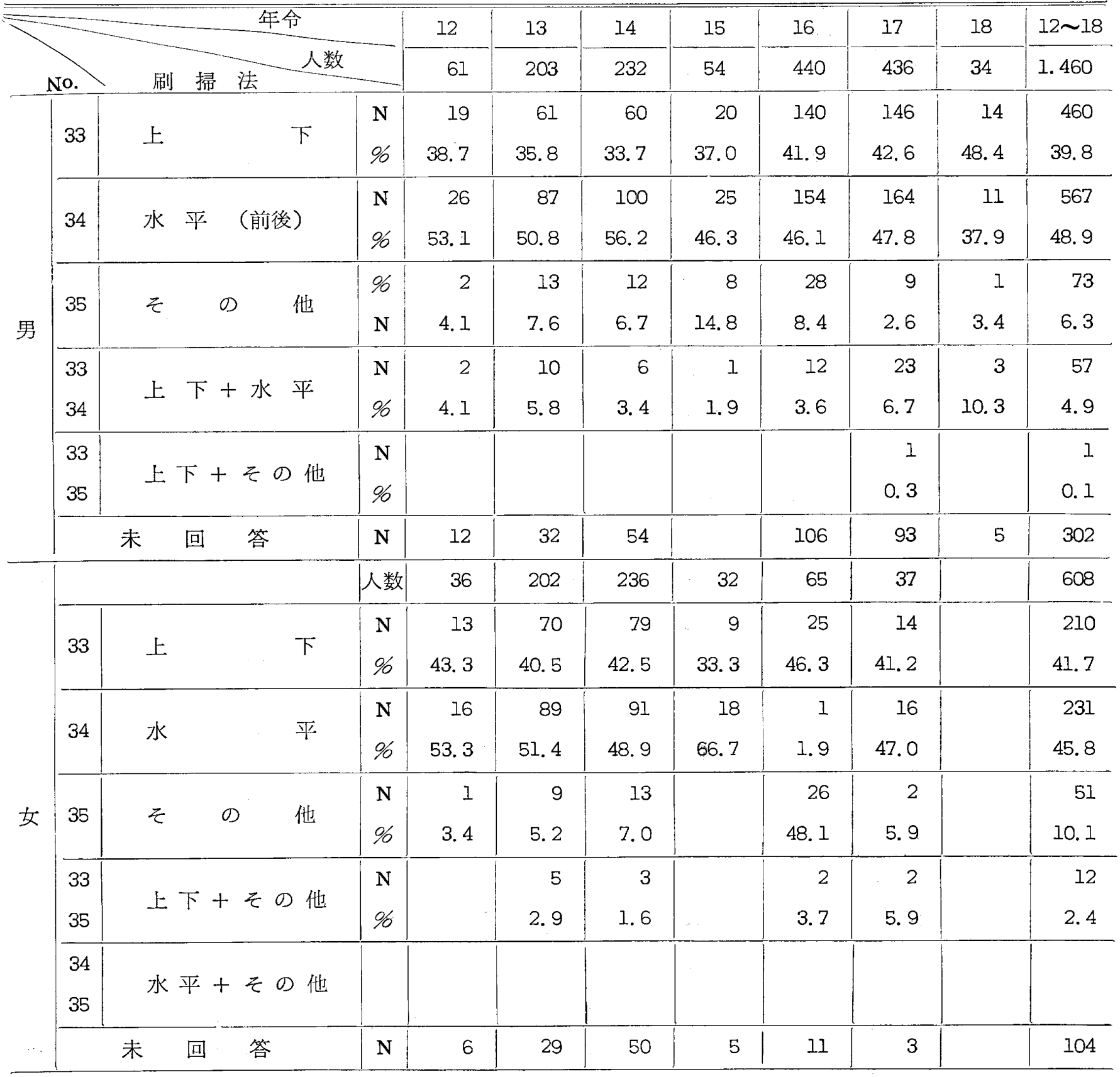

カ月， 2 力月の順である．男の平均（12〜I8才）は4.3 月, 女の平均 (12〜17才) は4.8月で, 男女間の差はほ とんごない.

木下他 (1962) 5) は1本の歯刷子の使用期間は3 カ月 がもっとも多かったと述べており，弓削（1966）37は同 じく!本の使用期間を調査し，歯牙沈着物の量を肉眼的 に認められなかったもの, 点状にみられたもの, 線状あ るいは帯状にみられたものの3者に区分し，歯牙记着物 の量とI本の䊝刷子の使用期間と 3 区分との間に差がみ られたという。榊原（1957）38)は蒾刷子の使用期間は3
カ月以上のものが半数以上であり，使用期間の長さに比 例して消耗度屯増大することを確かめている。また 月以上使用された Nylon 歯刷子の90\%はその刷毛が著 しく屈曲している上述べている．木村他（1969）30)は歯 刷子の使用限度の判定をおこない，173本中の107本つま り61.8\%の歯刷子が使用限度を越えており，使用不可能 と判定されたと発表している。

7 歯刷子の刷毛硬度

使用している歯刷子の刷毛の硬さは，表47のとおりで ある．男女とも中程度が圧倒的に多く，ついで硬い，軟 


\begin{tabular}{|c|c|c|c|c|c|c|c|c|c|c|}
\hline \multirow{2}{*}{\multicolumn{3}{|c|}{ No. 月 1 年令 }} & 12 & 13 & 14 & 15 & 16 & 17 & 18 & $12 \sim 18$ \\
\hline & & & 61 & 203 & 232 & 54 & 440 & 436 & 34 & 1,460 \\
\hline \multirow{27}{*}{59} & \multirow{2}{*}{1} & $\mathrm{~N}$ & 5 & 17 & 17 & 1 & 22 & 32 & 2 & 96 \\
\hline & & 96 & 8.3 & 8.8 & 7.6 & 2.4 & 5.7 & 8.5 & 6.3 & 7.4 \\
\hline & \multirow{2}{*}{2} & $\mathrm{~N}$ & 12 & 33 & 46 & 6 & 53 & 45 & 7 & 202 \\
\hline & & $\%$ & 20.0 & 17.0 & 20.5 & 14.3 & 13.9 & 11.9 & 21.9 & 15.4 \\
\hline & \multirow{2}{*}{3} & $\mathrm{~N}$ & 14 & 52 & 50 & 8 & 77 & 65 & 6 & 272 \\
\hline & & $\%$ & 23. 3 & 26.9 & 22.2 & 19.0 & 20.2 & 17.2 & 18.7 & 20.7 \\
\hline & \multirow{2}{*}{4} & $\mathrm{~N}$ & 10 & 42 & 61 & 16 & 96 & 92 & 10 & 327 \\
\hline & & $\%$ & 16.7 & 21.6 & 27.1 & 38.1 & 25.1 & 24.3 & 31.3 & 24.9 \\
\hline & \multirow{2}{*}{5} & $\mathrm{~N}$ & 3 & 7 & 8 & 3 & 9 & 17 & 1 & 48 \\
\hline & & $\%$ & 5.0 & 3.6 & 3.6 & 7.1 & 2.3 & 4.5 & -3.1 & 3.7 \\
\hline & \multirow{2}{*}{6} & $\mathrm{~N}$ & 15 & 30 & 31 & 4 & 86 & 91 & 5 & 262 \\
\hline & & $\%$ & 25.0 & 15.5 & 13.8 & 9.5 & 22.5 & 24.1 & 15.6 & 19.9 \\
\hline & \multirow{2}{*}{7} & $\mathrm{~N}$ & & 1 & & & 3 & 3 & & 7 \\
\hline & & $\%$ & & 0.5 & & & 0.8 & 0.8 & & 0.5 \\
\hline & \multirow{2}{*}{8} & $\mathrm{~N}$ & 1 & & & 1 & 2 & 2 & & 6 \\
\hline & & $\%$ & 1.7 & & & 2.4 & 0.5 & 0.5 & & 0.4 \\
\hline & \multirow{2}{*}{9} & $\mathrm{~N}$ & & & & & $I$ & 1 & & 2 \\
\hline & & $\%$ & & & & & 0.3 & 0.3 & & 0.2 \\
\hline & \multirow{2}{*}{10} & $\mathrm{~N}$ & & 1 & 1 & 1 & 1 & & & 4 \\
\hline & & $\%$ & & 0.5 & 0.4 & 2.4 & 0.3 & & & 0.3 \\
\hline & \multirow{2}{*}{$1 I$} & $N$ & & 1 & 1 & & & & & 2 \\
\hline & & $\%$ & & 0.5 & 0.4 & & & & & 0.2 \\
\hline & \multirow{2}{*}{12} & $\mathrm{~N}$ & & 9 & 10 & 2 & 32 & 30 & 1 & 84 \\
\hline & & $\%$ & & 4.6 & 4.4 & 4.8 & 8.4 & 7.9 & 3.1 & 6.4 \\
\hline & \multicolumn{2}{|c|}{ 未 回 答 } & 1 & 10 & 7 & 12 & 58 & 58 & 2 & 148 \\
\hline & \multirow{2}{*}{\multicolumn{2}{|c|}{$\begin{array}{cc}\mathrm{x} & \text { (月) } \\
\mathrm{Sx} & \text { (月) }\end{array}$}} & 3.74 & 3.93 & 3. 87 & 4.28 & 4.58 & 4.55 & 3.78 & 4.28 \\
\hline & & & 1.76 & 2.43 & 2.53 & 2.40 & 2.75 & 2.73 & 2.09 & 2.57 \\
\hline
\end{tabular}

かいの順になっている。

\section{8 㐘刷子の刷毛の種類}

使用している歯刷子の刷毛の種類は，表48の亡おりで ある。男女とも合成毛が断然多く，ついで豚毛の順にな っている.
木下他 (1963) 5) Nylon が57.8\%，刷毛が 30.9\% であった之報告している. 真泉 (1957) 39) は歯刷子の損 耗度について, 大多数のものは Nylon 荬刷子を使用し ており，その Nylon 歯刷子の半数以上は使用に耐えな いと思われるほど屈曲し，その程度は，粗悪品ほど甚し 


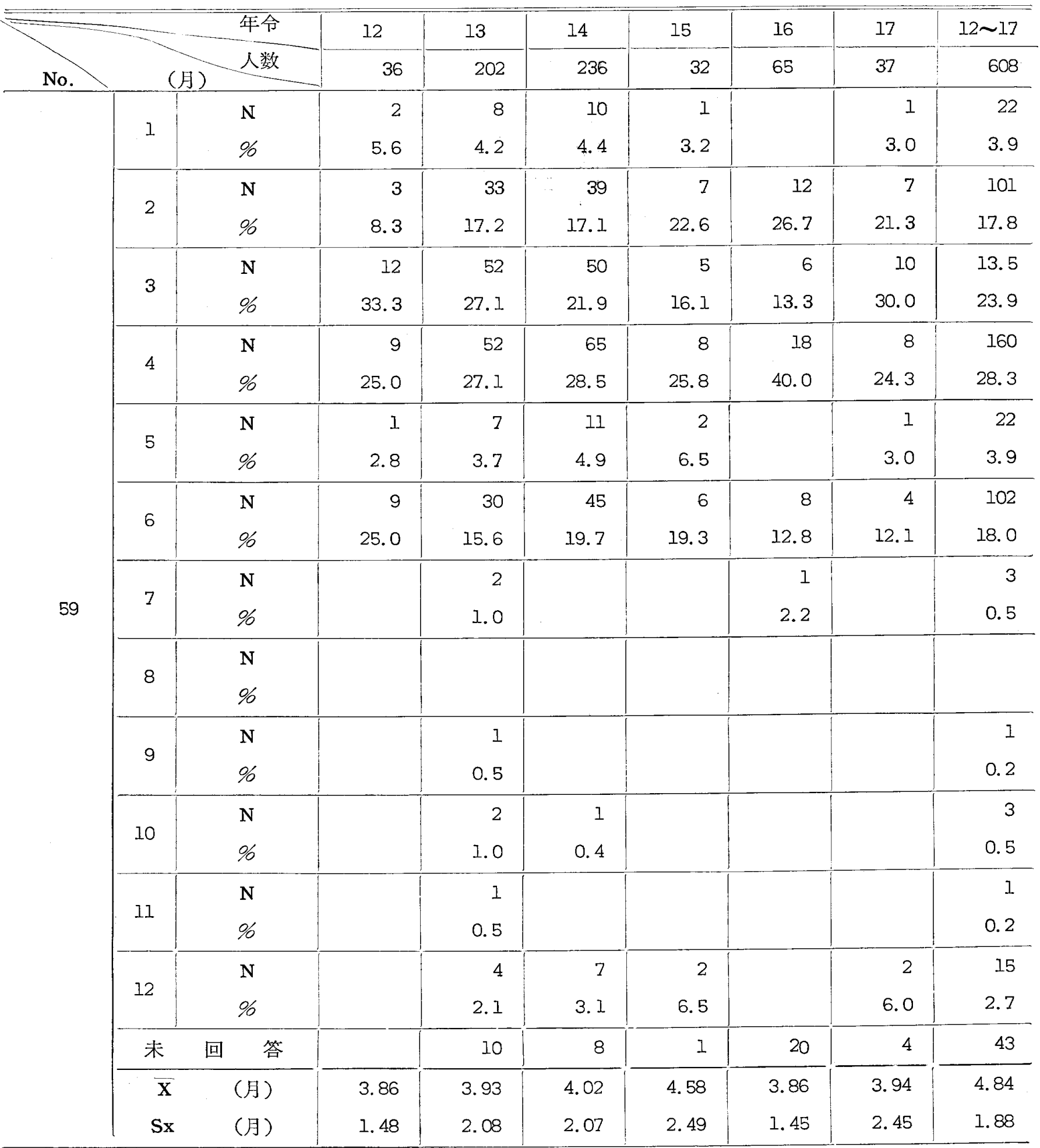

かったと述へている，柇原他（1957）38) は Nylon 対豚 毛の損耗度の比は，4：6であったと発表している。

9 画刷子の刷毛面の形態

使用している菌刷子の刷毛面の形態は，表49のとおり

である，刷毛面の形態を 4 つの型に分類した，すなわち
1 型（タフト型 Tuft prophylactic），2 型（凹型），3 型 (凸型)，4 型 (平面型) の4 種類に区別した. 男女 とも 4 型がもっとも多く，ついで 2 型， I型， 3 型の順 である。

金光 (1959) 299 はゴム工場の女子従業員の使用してい 
歯刷子の刷毛の硬度

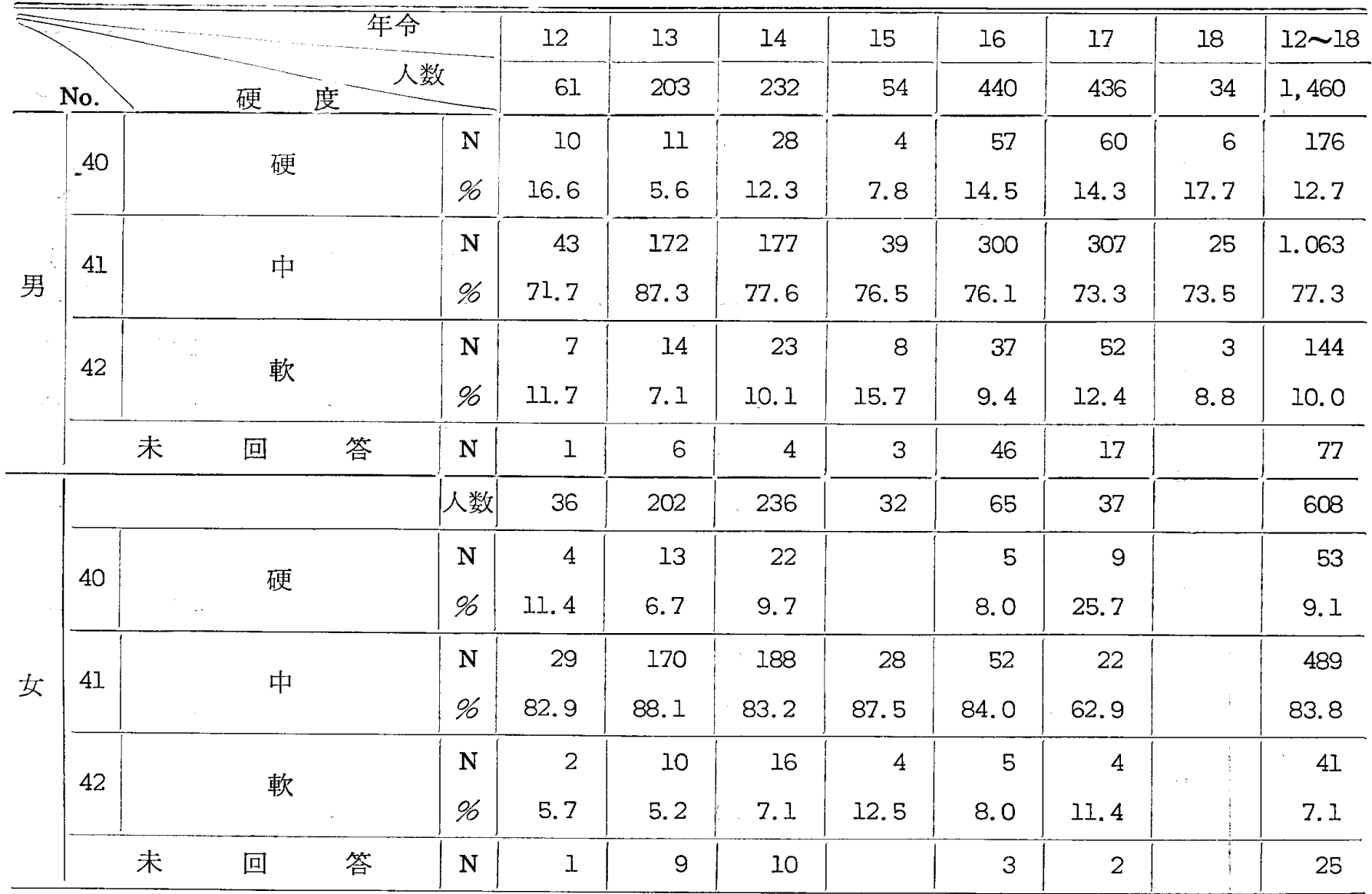

表 48 菌刷子の刷毛の種類

\begin{tabular}{|c|c|c|c|c|c|c|c|c|c|c|c|c|c|}
\hline \multirow{2}{*}{\multicolumn{2}{|c|}{ No. }} & \multicolumn{4}{|c|}{ 年令 } & 12 & 13 & 14 & 15 & 16 & 17 & 18 & $12 \sim 18$ \\
\hline & & \multicolumn{4}{|c|}{ 刷毛の種類 人数 } & 61 & 203 & 232 & 54 & 440 & 436 & 34 & 1.460 \\
\hline \multirow{9}{*}{ 男 } & 36 & $\Delta$ & 些 & F & $\mathbf{N}$ & 52 & 167 & 209 & 48 & 342 & 363 & 32 & 1.213 \\
\hline & & & & & $\%$ & 88.1 & 84.4 & 90.5 & 90.6 & 82.0 & 86.6 & 96.9 & 86.0 \\
\hline & \multirow{2}{*}{37} & \multirow{2}{*}{ 豚 } & & \multirow{2}{*}{ 毛 } & $\mathrm{N}$ & 3 & 23 & 15 & 3 & 51 & 35 & 1 & 131 \\
\hline & & & & & $\%$ & 5.1 & 11.6 & 6.5 & 5.6 & 12.2 & 8.4 & 3.1 & 9.3 \\
\hline & \multirow{2}{*}{38} & \multirow{2}{*}{ 狸 } & & \multirow{2}{*}{ 毛 } & $\mathbf{N}$ & 2 & 3 & 2 & 1 & 17 & 18 & & 43 \\
\hline & & & & & $\%$ & 3. 4 & 1.5 & 0.8 & 1.9 & 4.1 & 4. 3 & & 3.0 \\
\hline & \multirow{2}{*}{39} & \multirow{2}{*}{ そ } & \multirow{2}{*}{ の } & \multirow{2}{*}{ 他 } & $\mathrm{N}$ & 2 & 5 & 5 & 1 & 7 & 3 & & 23 \\
\hline & & & & & $\%$ & 3.4 & 2.5 & 2.2 & 1.9 & 1.7 & 0.7 & & 1.7 \\
\hline & & & 回 & 答 & $\mathbf{N}$ & 2 & $\therefore 5$ & 1 & 1 & 23 & 17 & 1 & 50 \\
\hline
\end{tabular}




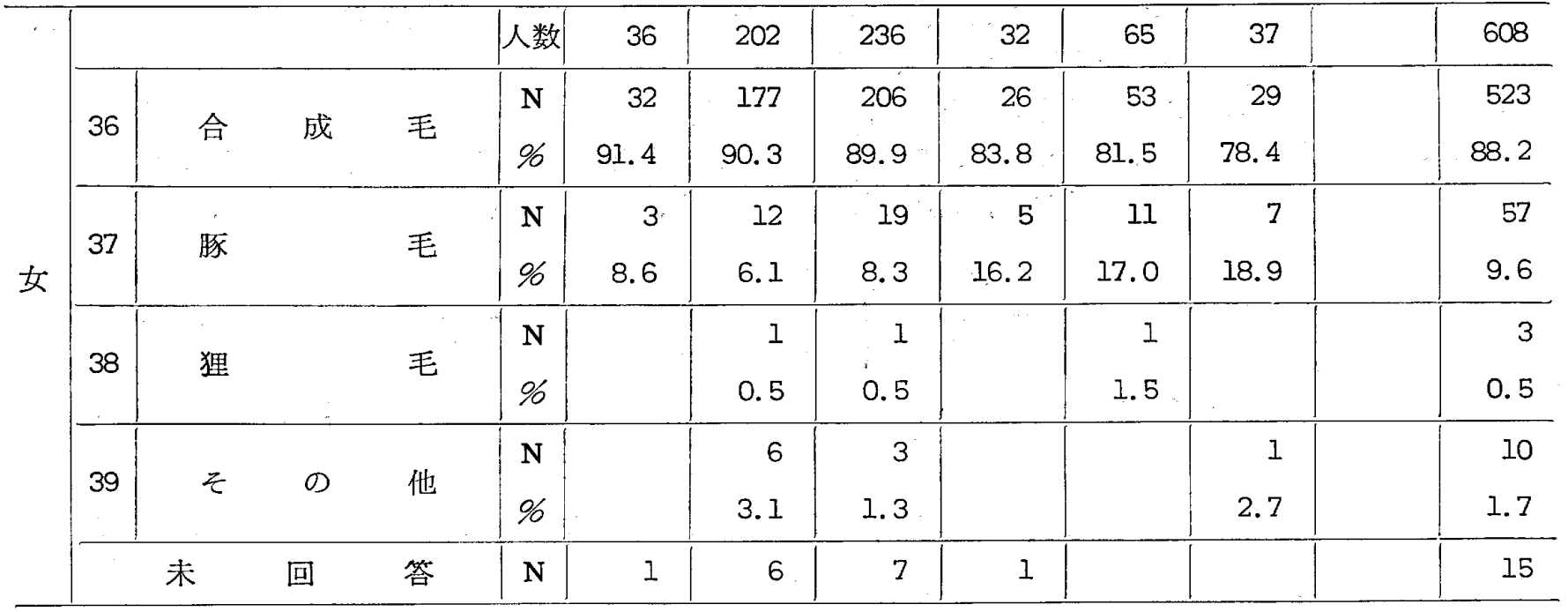

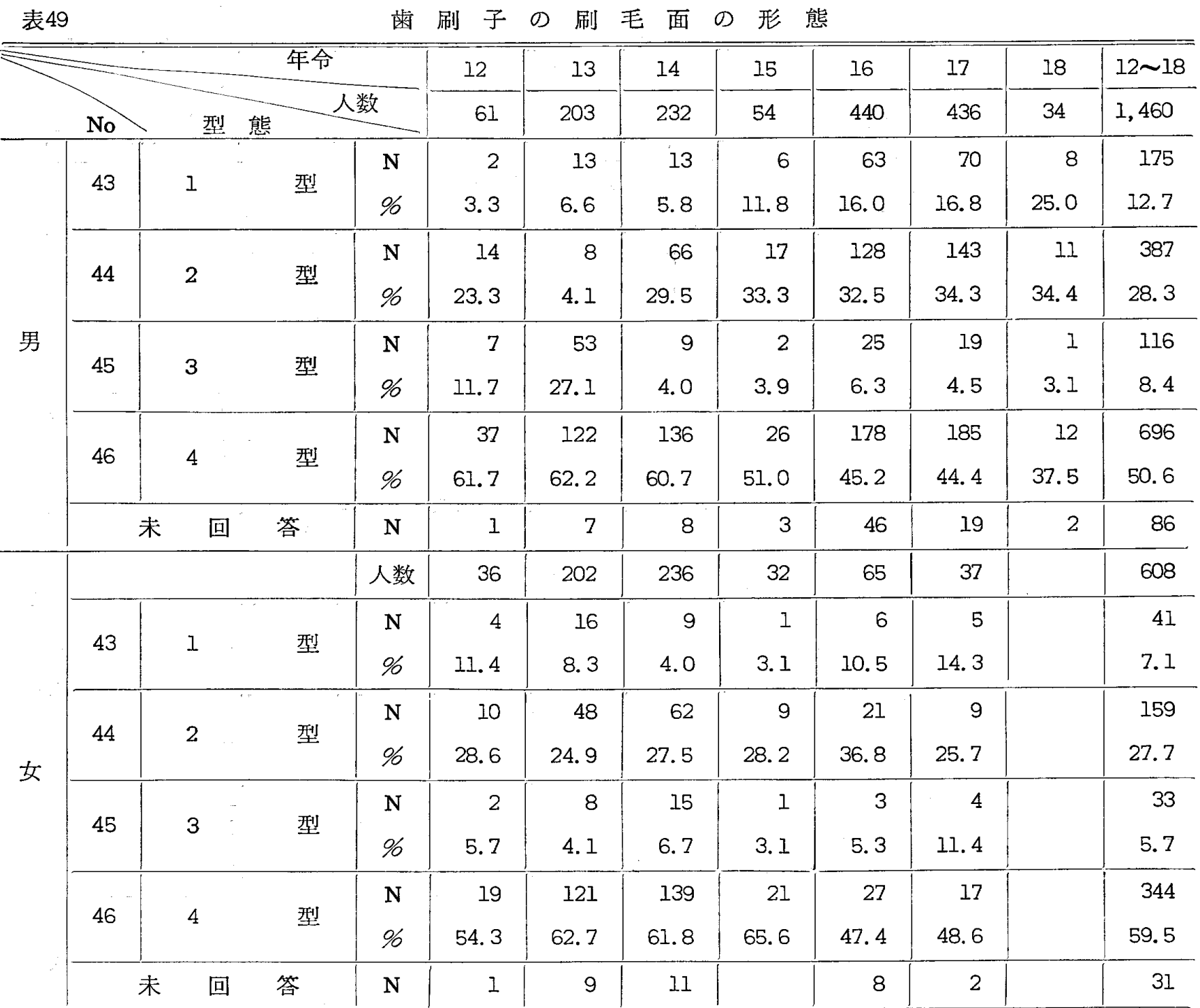

I型: Tuft Prophylactic型, 2 型 $:$ 凹型, 3 型 $:$ 凸型, 4 型 $:$ 平面型 
る䨑刷子の刷毛面の形態は, タフト型が68.7\%，水平型 が27.4\%，傾斜型が3.9\%であったと述べている．小幡 他（1963）40はH型が67.4\%であっとも多い之述へ，木 村他（1969）30)は植毛部の配置状態について，3 列の場 合には10段，4列の場合には12段が多いが，列数として
は 4 列のものが78\%で压倒的に多かったと述べている。 10 歯みがき剂の種類

使用している歯みがき剂の種類は，表50のと㧍りであ る．男女とも构り㐘みがきがもっとも多く，ついで粉歯 みがき，半ねりの順に少なくなっている，歯みがき剂を 表50 歯みがき剂の種 類

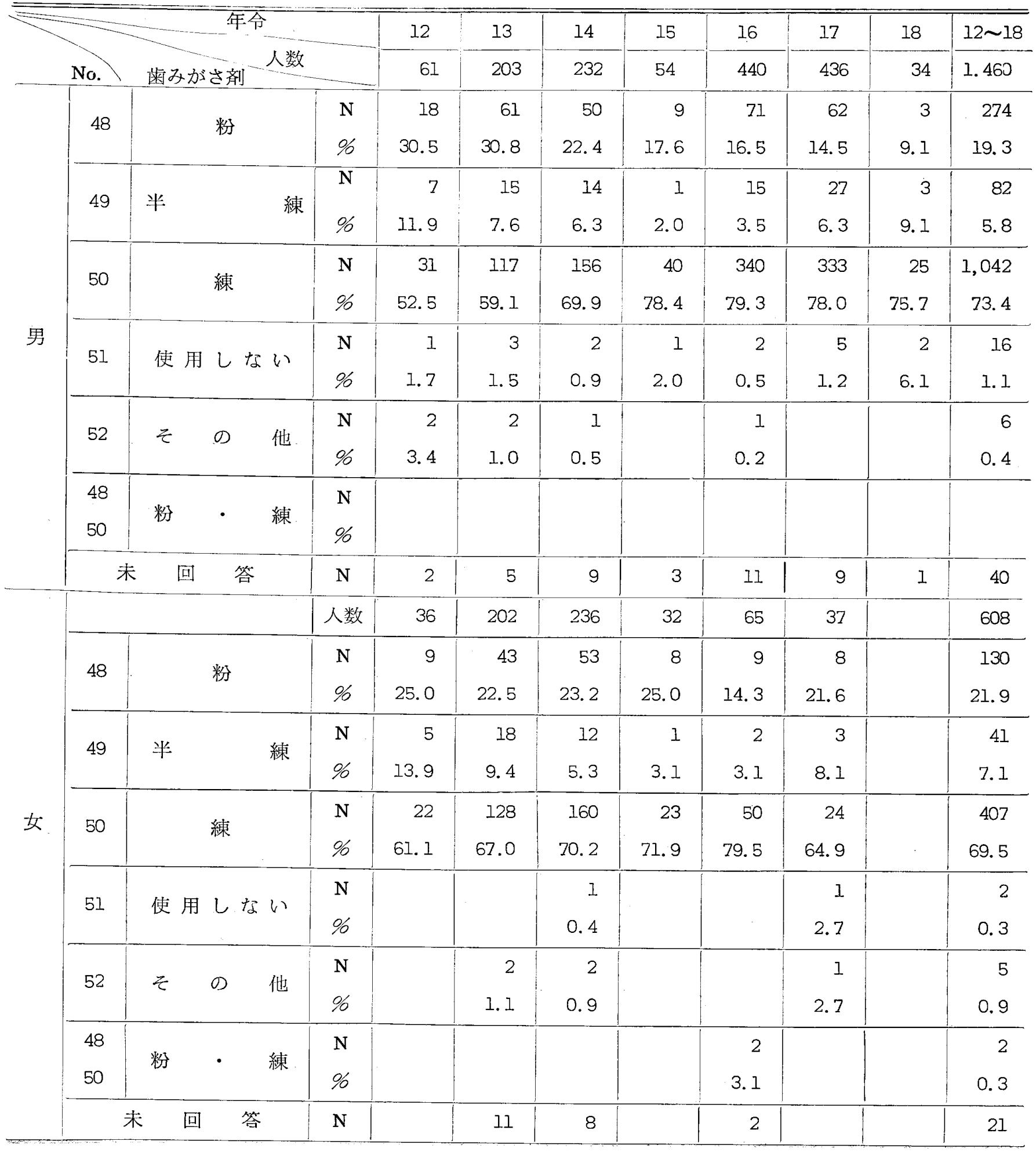


使用しない屯のが，男に1.1\%，女に0.3\%あったのは以 外であった。
11 小括

I 日の刷掃は朝食前が多く，I日の刷掃回数について 表51 男：う歯 数 の 自 覚

\begin{tabular}{|c|c|c|c|c|c|c|c|c|c|c|c|}
\hline 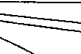 & \multicolumn{3}{|c|}{ 年令 } & 12 & 13 & 14 & 15 & 16 & 17 & 18 & $12 \sim 18$ \\
\hline No. & \multicolumn{3}{|c|}{5 菌 } & 61. & 203 & 232 & 54 & 440 & 436 & 34 & 1,460 \\
\hline \multirow{24}{*}{62} & \multirow{2}{*}{0} & & $\mathbf{N}$ & 11 & 48 & 70 & 18 & 172 & 121 & 14 & 454 \\
\hline & & & $\%$ & 18.0 & 23.9 & 30.6 & 33.3 & 39.9 & 28.1 & 41. 2 & 31.5 \\
\hline & \multirow{2}{*}{1} & & $\mathrm{~N}$ & 9 & 31 & 22 & 7 & 52 & 47 & 3 & 171 \\
\hline & & & $\%$ & 14.7 & 15.4 & 9.6 & 12.9 & 12.1 & 10.9 & 8.9 & 11.9 \\
\hline & \multirow{2}{*}{2} & & $\mathrm{~N}$ & 7 & 28 & 18 & 6 & 40 & 58 & 2 & 159 \\
\hline & & & $\%$ & 11.5 & 13.9 & 7.9 & 11.1 & 9.3 & 13.5 & 5.9 & 11.0 \\
\hline & \multirow{2}{*}{3} & & $\mathrm{~N}$ & 4 & 9 & 19 & 2 & 30 & 46 & 2 & 112 \\
\hline & & & $\%$ & 6.6 & 4.5 & 8.3 & 3.7 & 6.9 & 10.7 & 5.9 & 7.8 \\
\hline & \multirow{2}{*}{4} & & $\mathbf{N}$ & 2 & 9 & 9 & 3 & 16 & 34 & 4 & 77 \\
\hline & & & $\%$ & 3.3 & 4.5 & 3.9 & 5.6 & 3.7 & 7.9 & 11.7 & 5. 3 \\
\hline & \multirow{2}{*}{5} & & $\mathrm{~N}$ & 1 & 1 & 9 & & 3 & 16 & 1 & 31 \\
\hline & & & $\%$ & 1.6 & 0.5 & 3.9 & & 0.7 & 3.7 & 2.9 & 2.2 \\
\hline & \multirow{2}{*}{6} & & $\mathbf{N}$ & 3 & 4 & 3 & 1 & 3 & 3 & & 17 \\
\hline & & & $\%$ & 4.9 & 2.0 & 1.3 & 1.9 & 0.7 & 0.7 & & I. 2 \\
\hline & \multirow{2}{*}{7} & & $\mathrm{~N}$ & & 2 & 2 & & 3 & 2 & & 9 \\
\hline & & & $\%$ & & 1.0 & 0.9 & & 0.7 & 0.5 & & 0.7 \\
\hline & \multirow{2}{*}{8} & & $\mathbf{N}$ & & 1 & 2 & 1 & 1 & & & 5 \\
\hline & & & $\%$ & & 0.5 & 0.9 & 1.9 & 0.2 & & & 0.3 \\
\hline & \multirow{2}{*}{9} & & $\mathrm{~N}$ & 2 & & & & & & & 2 \\
\hline & & & $\%$ & 3.3 & & & & & & & 0.1 \\
\hline & \multirow{2}{*}{10} & & $\mathrm{~N}$ & & 1 & 1 & & & & & 2 \\
\hline & & & $\%$ & & 0.5 & 0.5 & & & & & 0.1 \\
\hline & \multirow{2}{*}{11} & & $\mathrm{~N}$ & & 1 & & & & & & 1 \\
\hline & & & $\%$ & & 0.5 & & & & & & 0.1 \\
\hline \multirow{2}{*}{63} & & & $\mathrm{~N}$ & 22 & 66 & 74 & & 111 & 103 & 8 & 400 \\
\hline & & & $\%$ & 36.1 & 32.8 & 32.3 & 29.6 & 25.8 & 24.0 & 23.5 & 27.8 \\
\hline & \multirow[t]{3}{*}{ 末 } & 回 & 答 & & 2 & 3 & & 9 & 6 & & 20 \\
\hline & & & （本） & 2.03 & 1.63 & 1.61 & 1. 34 & 1.09 & 1.68 & 1. 31 & 1.71 \\
\hline & & & （本） & 3.92 & 2.10 & 1.84 & 1.87 & 1.54 & 1.68 & 1.72 & 2.09 \\
\hline
\end{tabular}

No. 62 : う㐘の本数を知っている，63：う歯の本数を知らない. 
女：う歯数の，自 党

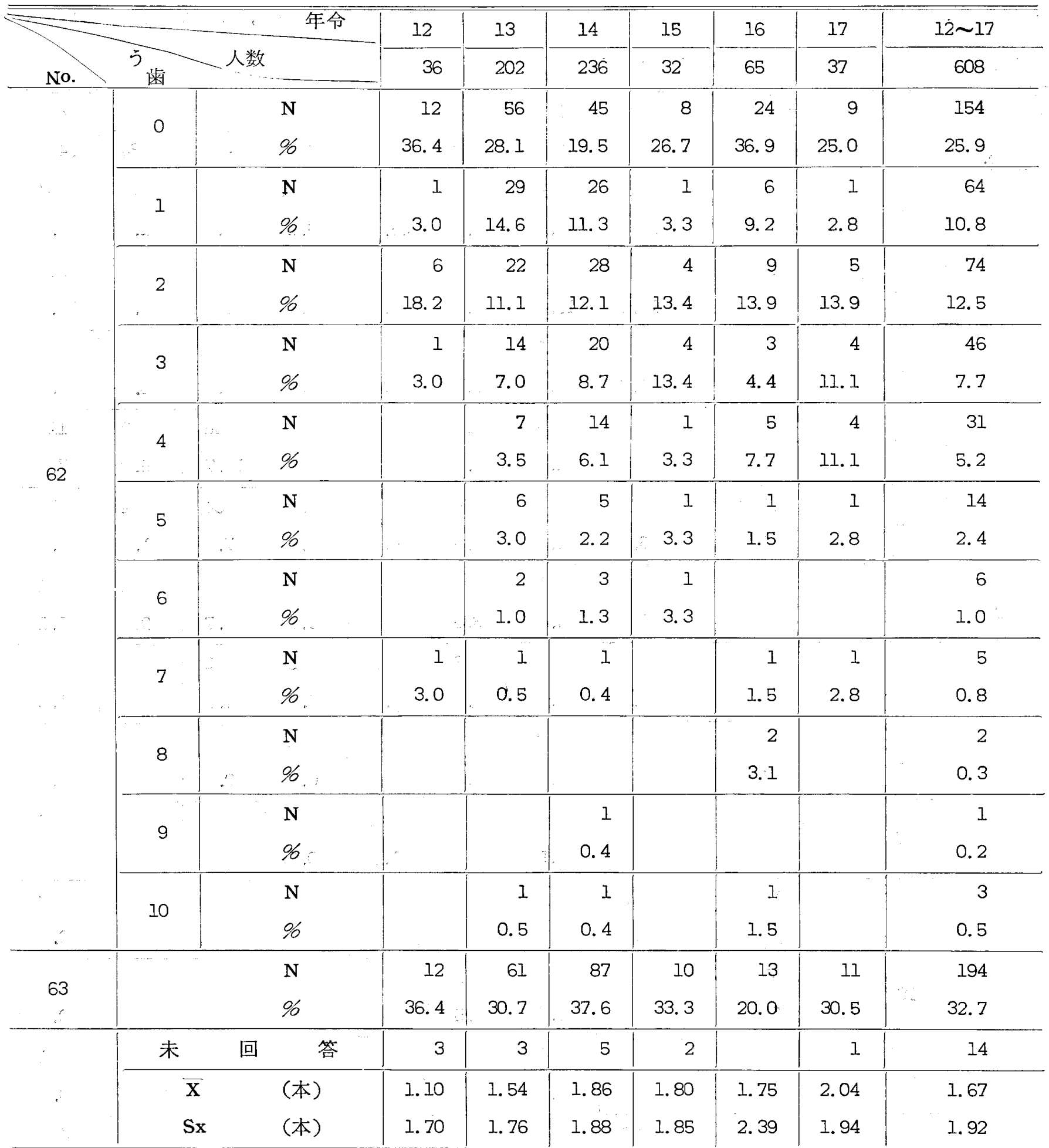

は1日1回がもっとも多く，刷掃時間は增令にとむない 少なくなっている．また刷掃しないものは男女とも增令 により加なり少なくなっている．刷掃方法は唇側面につ いては上下にみがくあのがあっとも多く，ついで上下と 水平の運動によるものが多いのに反し舌側面については
水平にみがくのが多かった，Robinson は37\%の人に廻 転法が抢てなわれていると述へているのに対し，著者の 調査でも，また歯口清掃法の普及が遅れていると思われ る. 歯刷子の使用期関に関しては, 男女とも 4 力月がも っとも多く，刷宒の硬さは中等度のものを使用するすの 
う歯”の治“療

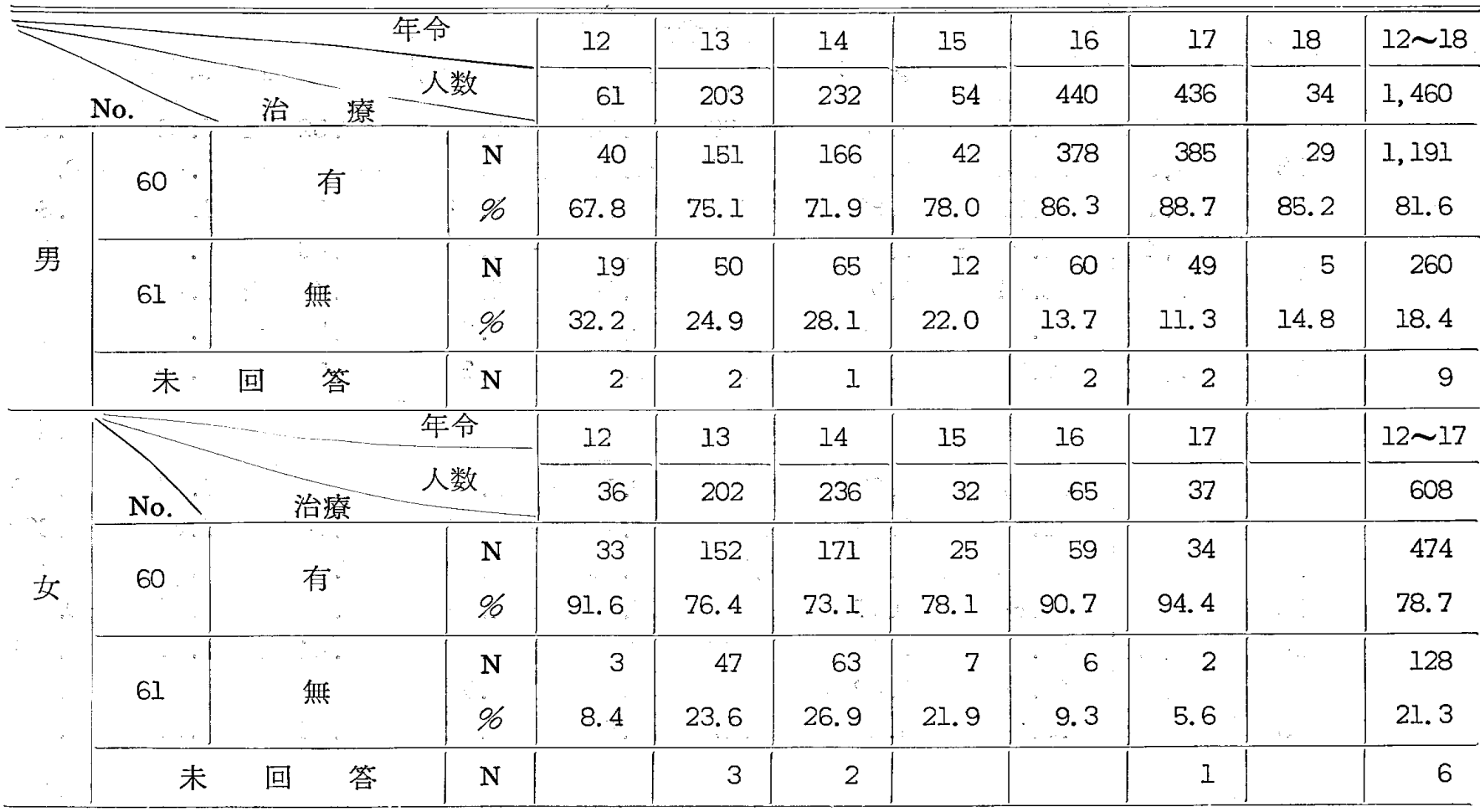

\begin{tabular}{|c|c|c|c|c|c|c|c|c|c|c|}
\hline & \multirow{2}{*}{ 年 令 } & \multicolumn{3}{|c|}{ 高温食物のすきな者 } & \multicolumn{3}{|c|}{ 低温食物のすきな者 } & \multicolumn{3}{|c|}{ 差 } \\
\hline & & $\mathrm{N}_{1}$ & $\mathrm{p}_{1} \pm$ & $\mathrm{Sp}_{1}(\%)$ & $\mathrm{N}_{2}$ & $\mathrm{p}_{2} \pm$ & $\mathrm{Sp}_{2}(\%)$ & $\mathrm{d}$ & $\operatorname{Sd}(\%)$ & $\mathrm{d} / \mathrm{Sd}$ \\
\hline \multirow{8}{*}{ 男 } & 12 & 441 & 12.69 & \pm 1.58 & $73^{\prime}$ & 15.07 & \pm 4.14 & -2.38 & \pm 4.43 & -0.537 \\
\hline & 13 & 1,424 & 16. 15 & \pm 0.94 & 100 & 17.00 & \pm 3.74 & -0.85 & \pm 3.86 & -0.220 \\
\hline & 14 & 1,396 & I5. 47 & \pm 0.96 & 108 & 12.04 & \pm 3.13 & 3.40 & $\pm \quad 3.27$ & 1.039 \\
\hline & 15 & 1,050 & 14.72 & \pm 1.10 & 112 & 19.42 & \pm 1.17 & -4.70 & \pm 1.61 & -2.919 \\
\hline & 16 & 1,430 & 21.18 & \pm 1.07 & 420 & 17.14 & \pm 1.83 & 4.40 & \pm 2.12 & 2. 075 \\
\hline & 17 & 1,606 & 23.79 & \pm 1.05 & 169 & 25.55 & \pm 3.31 & -1.76 & \pm 3.46 & -0.509 \\
\hline & 18 & 944 & 21.51 & \pm 1.33 & 56 & 19.64 & \pm 5.29 & 1.87 & \pm 5.46 & 0.342 \\
\hline & $\mathrm{MR} / \mathrm{S}_{\mathrm{MR}}$ & & & & & & & & & 0.289 \\
\hline \multirow{8}{*}{ 女 } & 12 & 1,564 & 17.71 & \pm 0.96 & 84 & 21.42 & $\pm \quad 4.47$ & -3.71 & \pm 4.57 & -0.812 \\
\hline & 13 & 2,244 & 18.49 & \pm 0.81 & 192 & 26.04 & \pm 3.16 & -7.55 & \pm 3.26 & -2.316 \\
\hline & 14 & 2,151 & 16.27 & \pm 0.79 & 140 & 5.72 & \pm 1.96 & 10.55 & \pm 2.10 & 5. 024 \\
\hline & 15 & 2,011 & 21.08 & \pm 0.90 & 168 & 19.05 & \pm 3.02 & 2.03 & \pm 3.14 & 0.647 \\
\hline & 16 & 1,782 & 23. 74 & \pm 1.60 & 140 & 17.86 & $\pm \quad 3.18$ & 5.88 & \pm 3.56 & 1.652 \\
\hline & 17 & 1799 & 28.18 & \pm 1.05 & 28 & 14.29 & \pm 2.09 & 13.89 & \pm 2.34 & 5.935 \\
\hline & 18 & 1291 & 27.03 & \pm 1.23 & 84 & 30.95 & \pm 1.59 & -3.92 & \pm 2.00 & -1.645 \\
\hline & $\mathrm{MR} / \mathrm{S}_{\mathrm{MR}}$ & & & & & & & & & 2.725 \\
\hline
\end{tabular}

$\mathrm{N}$ : 永久歯生歯数, $\mathrm{p} \pm \mathrm{Sp}(\%): \mathrm{DMF} \mathrm{T}$ 率, $\mathrm{d}: \mathrm{p}_{1}-\mathrm{p}_{2}(\%), \mathrm{Sd}: \mathrm{d}$ の標準誤差

$\mathrm{d} / \mathrm{Sd}$ 乙 $\mathrm{MR} / \mathrm{S}_{\mathrm{MR}}$ の $\alpha=0.05$, 有意義性は太字で示す，以下同じ. 


\begin{tabular}{|c|c|c|c|c|c|c|c|c|c|c|c|}
\hline & \multirow{2}{*}{ 年 令 } & \multicolumn{3}{|c|}{ 甘味食物のすきな者 } & \multicolumn{3}{|c|}{ 甘味食物のきらいな者 } & \multicolumn{4}{|c|}{ 差 } \\
\hline & & $\mathrm{N}_{1}$ & $\mathbf{p}_{1} \pm$ & $\mathrm{Sp}_{1}(\not \sigma)$ & $\mathrm{N}_{2}$ & $\mathrm{p}_{2} \pm$ & $\mathrm{Sp}_{2}(\varnothing)$ & d & \pm & $\operatorname{Sd}(\%)$ & $\mathrm{d} / \mathrm{Sd}$ \\
\hline \multirow{8}{*}{ 男 } & 12 & 762 & 17.06 & $\pm \quad 1.36$ & 156 & 11.54 & \pm 2.55 & 6.52 & \pm & 2.89 & 2.256 \\
\hline & 13 & 1,837 & 15.84 & \pm 2.69 & 670 & 17.31 & $\pm \quad 1.45$ & -1.47 & \pm & 2.62 & -0.561 \\
\hline & .14 & 1. 768 & 15.55 & \pm 0.86 & 929 & 13.35 & \pm 1.11 & 2.20 & \pm & 1.41 & 1.560 \\
\hline & 15 & 1,416 & 17.87 & \pm 1.01 & 361 & 17.45 & \pm 1.99 & 0.43 & \pm & 2.23 & 0.193 \\
\hline & 16 & 2,692 & 20.54 & \pm 0.77 & 309 & 20.06 & \pm 2.27 & 0.48 & \pm & 2.40 & 0.200 \\
\hline & 17 & 2,366 & 25.82 & \pm 0.89 & 684 & 19.29 & \pm 1.50 & 6.53 & \pm & 1.73 & 3. 775 \\
\hline & 18 & 1,046 & 22.75 & \pm 1.29 & 287 & 20.21 & \pm 2.36 & 2.54 & \pm & 2.69 & 0.944 \\
\hline & $\mathrm{MR} / \mathrm{S}_{\mathrm{MR}}$ & & & & & & & & & & 2. 928 \\
\hline \multirow{8}{*}{ 女 } & 12 & 2,283 & 18.22 & \pm 0.80 & 881 & 15.11 & \pm 1.20 & 3.11 & \pm & 1.44 & 2.159 \\
\hline & 13 & 3,093 & 18.59 & \pm 0.69 & 1,327 & 17.25 & \pm 1.14 & 1.34 & \pm & 1.33 & 1.008 \\
\hline & 14 & 2,964 & 16.63 & \pm 0.67 & 1,107 & 20.05 & \pm 1.20 & -3.42 & \pm & 1.39 & -2.460 \\
\hline & 15 & 2,816 & 21.56 & \pm 0.77 & 754 & 20.16 & \pm 1.45 & 1.40 & \pm & 1.64 & 0.854 \\
\hline & 16 & 2,425 & 22.93 & \pm 0.51 & 449 & 20.49 & $\pm \quad 1.90$ & 2.44 & \pm & 1.97 & 1.238 \\
\hline & 17 & 1,882 & 27.58 & \pm 1.02 & 618 & 24.59 & \pm 1.73 & 2.99 & \pm & 2.01 & 1. 488 \\
\hline & 18 & 1,238 & 29.24 & \pm 1.29 & 532 & 25.00 & \pm 1.87 & 4.24 & \pm & 2.27 & 1.867 \\
\hline & $\mathrm{R} / \mathrm{S}_{\mathrm{MR}}$ & & & & & & & & & & 2.147 \\
\hline
\end{tabular}

$\mathrm{N}$ : 永久歯生歯数

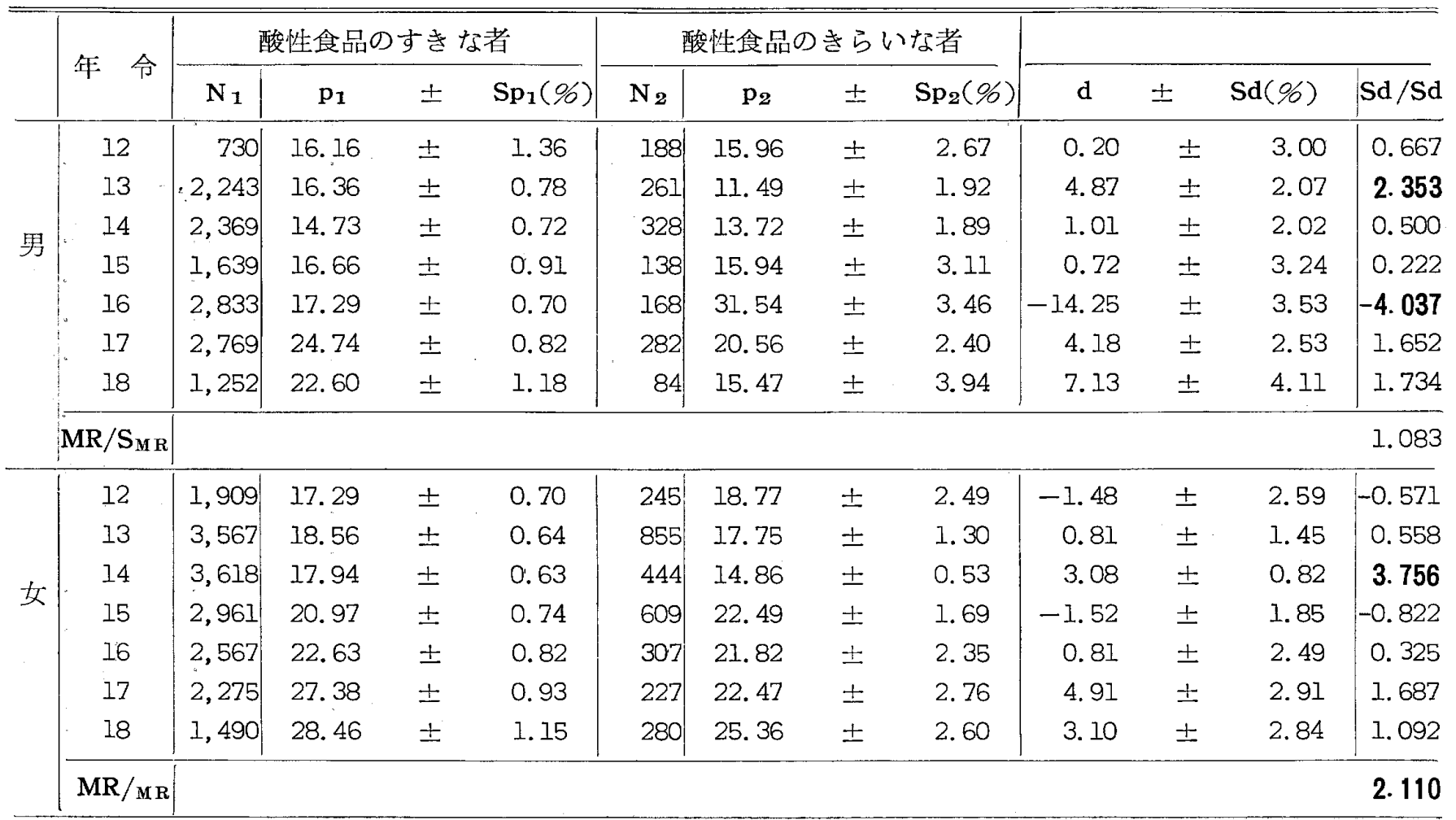

$\mathrm{N}$ : 永久歯生歯数, $\mathrm{p} \pm \mathrm{Sp}: \mathrm{DMFT}$ 率 


\begin{tabular}{|c|c|c|c|c|c|c|c|c|c|c|c|c|c|}
\hline & \multirow{2}{*}{ 年 令 } & \multicolumn{4}{|c|}{ アルカリ食品のすきな者 } & \multicolumn{4}{|c|}{ アルカリ食品のきらいな者 } & \multicolumn{4}{|c|}{ 差 } \\
\hline & & $\mathrm{N}_{1}$ & $\mathrm{p}_{\mathbf{1}}$ & \pm & $\mathrm{Sp}_{1}(\%)$ & $\mathrm{N}_{2}$ & $\mathbf{p}_{2}$ & \pm & $\mathrm{Sp}_{2}(\%)$ & d & \pm & $\operatorname{Sd}(\%)$ & $\mathrm{d} / \mathrm{Sd}$ \\
\hline \multirow{8}{*}{ 男 } & 12 & 867 & 16.83 & \pm & 1.26 & 51 & 3.92 & \pm & 2.71 & 2.91 & \pm & 2.95 & 0.986 \\
\hline & 13 & 2,241 & 15.66 & \pm & 0.76 & 266 & 14.04 & \pm & 2.35 & 1.62 & \pm & 2.47 & 0.655 \\
\hline & 14 & 2,530 & 15.09 & \pm & 0.70 & 167 & 10.77 & \pm & 2.39 & 4. 32 & \pm & 2.49 & 1.735 \\
\hline & 15 & 1,669 & 17.91 & \pm & 0.93 & 112 & 12.50 & \pm & 3. 10 & 5.41 & \pm & 3.24 & 1.669 \\
\hline & 16 & 2,945 & 20.71 & \pm & 2.35 & 56 & 7.14 & \pm & 3.43 & 13.57 & \pm & 4. 16 & 3. 262 \\
\hline & 17 & 2,855 & 24.02 & \pm & 0.79 & 195 & 29.23 & \pm & 3.16 & -5.21 & \pm & 3.26 & -1.598 \\
\hline & 18 & 1,280 & 22.11 & \pm & 1. 15 & 56 & 23. 21 & \pm & 5.56 & -1.10 & \pm & 5.68 & -0.194 \\
\hline & $\mathrm{MR} / \mathrm{S}_{\mathrm{MR}}$ & \multicolumn{12}{|r|}{2.282} \\
\hline \multirow{7}{*}{ 女 } & 12 & 2,922 & 17.45 & \pm & 0.76 & 237 & 16.46 & \pm & 2.40 & 0.99 & \pm & 2.57 & 0.393 \\
\hline & 13 & 4,126 & 18.27 & \pm & 0.63 & 286 & 17.83 & \pm & 2.26 & 0.44 & \pm & 2.35 & 0.187 \\
\hline & 14 & 3,902 & 17.48 & \pm & 0.60 & 167 & 19.76 & \pm & 3.10 & -2.28 & \pm & 3.16 & -0.721 \\
\hline & 15 & 3,403 & 21.45 & \pm & 0.70 & 167 & 17.37 & \pm & 2.93 & 4.08 & \pm & 3.01 & 1.356 \\
\hline & 16 & 2,756 & 22.28 & \pm & 0.78 & 112 & 30.36 & \pm & 4. 24 & -8.08 & \pm & 4. 34 & -1.862 \\
\hline & 17 & 2,470 & 26.68 & \pm & 0.88 & 28 & 42.85 & \pm & 9.32 & -16.17 & \pm & 9.36 & -1.727 \\
\hline & 18 & 1,742 & 28.01 & \pm & 1.07 & 28 & 25.00 & \pm & 8.12 & 3.01 & \pm & 8.19 & 0.367 \\
\hline
\end{tabular}

$\mathrm{N}_{1}, \mathrm{~N}_{2}$ : 永久歯生歯数, $\mathrm{P}_{1}, \mathrm{P}_{2}: \mathrm{DM} \mathrm{F}$ T率 $(\%), \mathrm{Sp}_{1}, \mathrm{Sp}_{2}: \mathrm{P}_{1}, \mathrm{P}_{2}$ の標準偏差

が多く，刷毛の種類としては合成毛，刷毛面の形態とし ては平面型があっとも多く使用されていた。全体的にみ て，㐘刷子に関してはかなり正しい知識を有しているよ うに思われた。

〔V】食物の種類とう崡についての調查成績

1 う蒌数の自覚

う歯を何本もっているか知らない者は表51，52のよう に男 (12〜18才) が27.8\%，女（12〜17才）が32.7\%で 男女之あ增令沉れてわずかに減少している。1/3亿近い 中学・高校生がう歯数を知らないということは考えさせ られる。

\section{2 う蒾の治療}

う雪の治療の有無は，表53のと抢りである．治療した ものは, 男 (12〜18才) が81.6\%，女（12〜17才）が 78.7\%で男女間の差はない，男女之も増令につれて治療 した者がわずかに増している。

3 高温食物とう料

高温食物のすきなもの，きらいなものの DMFT 率 (DMFT/生䨑数比率名)は，表54の之抢りである。男は 高温食物のすきなむのときらいなものの DMFT 率の差 がほとんどないが，女では高温食物のすきなものがきら いなあのよりも DMFT 率は高い。
4 甘味食物とう歯

甘味食物のすきなものと，きらいなるのの DMFT 率 は，表55のとおりである．男女とむ甘味食物のすきなる のがきらいなむのよりあ DMFT 率が高い.

5 酸性食物（米食, 肉, 魚, 卵など) とう荬

酸性食物（米食，肉，魚，卵など）のすきなあのとき らいなあのの DMFT 率は表56の之抢りである，男女之 あ酸性食物のすきなむのがきらいなものよりも DMFT 率が高い。

6 アルカリ性食物（果物，野菜，牛乳など）之う歯 アルカリ性食物（果物，野菜，牛乳など）のすきなも のときらいなあのの DMFT 率は表57の上おりである. 男ではアルカリ性食物のすきなものがきらいなものより も DMFT 率が高く，女では両者の差はほ之んどない。

\section{むす び}

質問型式による記入式調査により環境因子を探究する ことは，疾病の予防，治療上重要である。また，その集 団の口腔衛生知識の程度を知り，保健教育ならびに保健 指導上きわゆて重要なむのである．著者は歯肉の健康状 態と食物との関係について，質問型式による記入式調查 を扟てない，両者の関係をあきらかにした．また歯の刷 
掃について調查し，北九州市内中・高校生の刷掃に関す る衛生学的知識の程度を知り得た. 研究の結果はつぎの 通りである。

I 歯肉の健康状態に関する調査成績

A 質問型式による調查成績

（1）起床時に抢ける口腔内の不快感：ね怔るという あのは，男が26.6\%，女が26.5\%で増令による增減は著 しくない.

（2）崡みがき時に抬ける出血の疼痛：出血するとい うあのは男が $20.9 \%$ ，女が22.7\%であり，疼痛は男が 5.3\%，女が10.4\%で増令による増減は著しくない。

（3）食片压入：はさまるというあのは，男が57.2 \%,女が46.6\%である。

（4）排膿：排膿があるものは男が $2.6 \%$ ，女が4. $3 \%$ で，中学・高校生時代は年令につれて増減はない.

（5）歯の動摇：動くというあのは，男が16.2\%，女 が19.8\%であり，男女とも14才以後は減少している。

B 質問型式による調查之菌肉の健康調查成績

（1）歯肉の健康状態健康なむのは男が553人中 $419 人$ の75.8\%，女が811人中590人の $72.8 \%$ ，歯肉 炎は男が 253 人中 122 人の $22.1 \%$ ，女が811人中 195 人の $24.0 \%$ ，歯 槽膿漏症は男が553人中に 12 人の $2.1 \%$ ，女 が 811 人中 26 人の $3.2 \%$ であった.

(2) Stippling： Stippling を有するむのは，男が $28.1 \%$ ，女が39.0\%である。歯肉炎之歯槽膿漏症は Stippling が(一)のあのにおいて ( $( \pm),(+)$ のあの の場合よりも多い.

（3）Melanin 色素沈着: Melanin色素沈着のある屯 のは男が0.9\%，女が2.7\%である，歯肉の健康者，歯肉 炎および菌槽膿漏症のいずれも Melanin 色素沈着の (一), (土), (十)の差は著しくない.

(4) 歯石：歯石があるのは男が17.7\%，女が12.1\% である。歯槽膿漏症は歯石のある吨のにおいてでくわず 加多い。

II 食物の嗜好之䨑肉の健康状態についての調查成績

（1）歯肉の健康なむのは，男が $75.8 \%$ ，女为 72.8 $\%$, 歯肉炎は男が $22.1 \%$ ，女が $24.0 \%$ ，歯槽膿漏症は男 が2.1\%，女が3.2\%である。

(2) 歯肉の健康なもの，歯肉炎打よご歯槽膿漏症の いずれむ，つぎの食物のすきなむのにきらいなものにお けるよりも多い, 高温, 甘味, 硬質, 軟質, 野菜類, 肉 類である。

（3）歯肉の健康なもの，崡肉炎拈よび歯槽膿漏症の いずれもいわゆる猫舌のものが少ない，
（4）各種因子の百分比成績食物のすきなるのは，甘 味食物が78.0\%女が74.0\%；辛味食物は男が80.9\%，女 が86. 4\% ; 肉類は男が85.7\%，女が75.8\%；魚類は男が $53.7 \%$ ，女が53.4\%；酸性食物は男が89.9\%，女が89.6 \% ; アルカリ性食物は男が93.6\%，女が95.3\%である. きらいな食物では，高温食物は男が7.0\%，女が3.7\%； 硬質食物は男が8.3\%，女が10.9\%であった。

III 歯の刷掃調查成績

（1）1日における歯みがきの時期㧍よび意見：男女 とあ朝食前があっとも多く, ついで就寝前, 朝食後の順 であり，男女とも食後がよいという意見が多かった。

（2）1 回の歯みがきに要する時間: 男女とす平均 3 分で，年令を増すにつれてわずかに少なくなっている.

（3）I日に打汀歯みがきの回数：男女とも1回み がくものがあっとも多く，女が男よりあみがくあのが多 い. 男の12才にみがかないものは23\%で年令の増すにつ れ減少し，18才では5\%のものがみがかない。

（4）歯冠唇側の刷掃方法：男女とも上下があっと屯 多い.

（5）歯冠舌側の刷掃方法：みがくものは男が78\%， 女が83\%で増令的差は著しくなく，男女とも水平がもっ 之多い。

（6）1本の歯刷子の使用期間：男 が平均4.3月，女 が4.8月であった。

（Z）歯刷子の刷毛硬度：男女とむ中等度が圧倒的に 多く.

（8）歯刷子の刷毛の種類：男女とも合成毛が断然多 W.

（9）歯刷子の刷毛面の形態：男女とも平面型があっ とむ多い.

（10）畨みがき剤の種類：男女とあねり歯みがきがあ っとも多い.

IV 食物の種類とう歯についての調查成績

う歯数を知らないあのは全体の約 $1 / 3$ 近くああるが，治 療をしたものは男が81.6\%，女が78.2\%で増令につれて わずかに增している，男女ともに甘味食物，酸性食物の すきなものにう歯が多く，男のアルカリ性食物，女の高 温食物をすきなものにう歯が多い。

擱筆にあたり終始御懇切なる御指導之御校閲を賜わっ た荷宮教授に深謝する．また種々便宜をあたえられた吉 田光雄教授ならびに山本博武助教授，御助言を賜わった 上野正康教授ならびに林一郎教授に感謝し，資料整理に 御協力を賜わった朝倉光子主任 技師ならびに保 存学教 室，鎌田政秀元助教授之関係学校当局に樑く感謝の意を 
表します。

\section{引用: 文 献}

I. 松村敏治 - 他 ; 高等学校生徒歯周疾患患者の臨床的 観察 (会)：口腔衛生学会雑誌， 7 ( 1 )，28, (1957).

2. 松井昌 - 他; 青年期に打りる菌周咨患の $2 ， 3$ の検 索成績について，特に肉眼的検査とレントゲンる像 との関係の検討 : 口腔科学紀要, 1，674-678, (1959),

3. 三宅猛夫; 歯周組織疾患に関する臨床統計的調査研 究, 特に化瀻従業員を被検対象として: 口腔科学紀 要, 3, 1-35, (1963).

4. 石川 純, 山崎敬介; 現代人の食物之畨周疾患の関 係 (会): 口腔病学会雑誌, 29, 209, (1962).

5. 木下四郎・他; 歯周疾患の原因之臨床所見亡に関す る統計的観察：口腔病学会雑誌，30 (2)，137一 144, (1963).

6. 今川与曹; 最近の我が国における歯槽膿漏症に関す る研究の動向：歯界展望，12，5，(1956).

7. 岩井直信; 歯周突患予防としての歯磨郕に関する研 究 : 口空衛生学会雑誌, 19, 9-31, (1969).

8 . 口腔衛生学会雪牙周围組織調查委員会; 我が国にお ける橉牙周囲組織疾患汇関する調查報告：口腔衛生 学会雑誌，19，43-59, (1969).

9. 南清治・他; 某化繊工場に打りる歯周組織検晾結果 : 日本口腔科学会雑誌，5，329，(1959).

10. 原 琒; 歯槽膿漏症の病因関する臨床的研究, 特任青少年の歯周組織の臨床的所見からの推察 : ロ 腔科学紀要, 3 (2), 162-194, (1963).

11. 安藤義昭・他; 菌敬線形態亡色素沈着 : 日本口腔科 学会誌, 3 ( 3 ), 159, (1959).

12. 長谷川幸久; 某金属砝山抗内従業員の口腔内, 特に

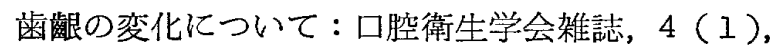
28-37, (1955).

13. 長谷川幸久: 某金属鉱山抗内夫の口腔衛生学的研究 : 口腔衛生学会雑誌, 10 (4), 210-247, (1960).

14. 松村敏治・他; 学童䨑肉の色素沈着に関する診査成 績について (会): 口架衛生学会雑誌, 12 (34), 50, (1962).

15, 南清治・他；青少年におりる歯周組織突患の臨床観 察特に逐年的観察 (会)：日本口腔科学会雑誌，5, 330, (1956).
16. “森本基・他; 事務所に抢ける歯周疾患予防に関する 研究 (会): 口腔衛生学会雑誌. 12, 51，(1962).

17. 徳植進 - 他; 妊産婦の口腔内変化䠛蝕之唾液 $\mathrm{pH}$ 及 び歯鹋状態に就いいて概括：歯界展望，12，970, (1955).

18. 河合幹; 日窒秩父釷山従業員の環境之歯石沈着状態

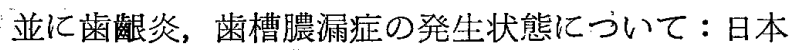
口腔科学会雑誌, 5, 169, (1956).

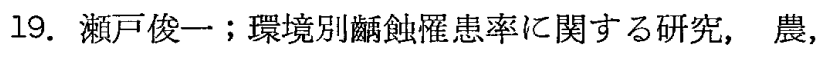
山, 魚村についての比較: 口腔衛生学会雑誌, 6 (4), 133-152, (1957).

20. 村上成隆 ; 某刑務所受刑者の口腔診查成績について : 茵科学報, 59, 36, (1959).

21. 和泉潔; 日本鉱業日立鉱山本山従業員の環境々歯石 沈着状態並に菌肉炎, 歯槽膿漏症の発生状態に就い $\tau$, 日本口腔科学会雑誌, 9, 73, (1960).

22. 安藤義一・他 : 歯牙沈着物の統計的観察 : 東京歯科 大学解剖学教室集業室, 績8, 1-5, (1958).

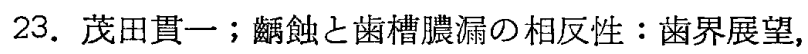
30, 465-477, (1967).

24. Waugh L. M. ; 石川純他 (4) より引用

25. Burwaser and Hill ; 石川純他 (4) より引用 (1962).

26. 河西一秀 -他; 歯周突患们関する研究, 飼料の固さ が犬の歯周組織に及ぼす影響（会）：日本歯槽膿漏 学会雑誌, 9 (1), 30, (166).

27. 村下秀雄; 誦蝕之曾槽膿漏との相反性に関する研究 （II）事業体，官公置を対照とした口腔診査成績， 特に唾液の水菜イオン濃度と赀好品の関連性につい $\tau:$ 岐阜医科大学紀要, 8 (3), 613-647, (1960).

28. 川島仁; 学童の口空の清掃度と清潔度との関係 : ロ 腔衛生学会雑誌, 3 ( 2), 91, (1949).

29. 金光一郎：某ゴム工場に於ける集団生活従業員の口 腔衛生に関する診査: 口腔衛生学会雑誌, 9 ( 3 ), 49, (1959).

30. 木村吉太郎・他；ある集団に於ける㐘ブラシ使用状 況について, 歯科学報, 69 (1), 21-22, (1969).

31. 岡本清縜・他; 常用ハブラシの使用後の観察 : 口腔 衛生学会雑誌, 9 (4), 126-135, (1959).

32. Fosdick; cit. from H. Goose and R. L. Hartles, Principles of Preve ntive Dentistry. 2526, Pergamon Press, (1964),

33. 厚生省; 歯口清掃指導の手びき : 36, (1967). 
34. Robinson, H. B. G; 岡本清絽 : (31) より引用, 134, (1959).

35. 石川純・他; 各種の歯刷子を使った時の歯や歯周組 織に加わる圧力: 口腔病学会雑誌, $16(4), 2161$ -27, (1966).

36. 今西孝博・他; 幼児に対する刷掃指導に関する臨床 成績 : 歯科学報， 67 (10). 1268-1374, (1969).

37. 弓削朝子；歯牙沈着物を左右する二，三の囚子：口
腔衛生学会倠誌, 16 (4), (1966).

38. 棚原悠紀田郎・他; 常用歯刷子の消耗度に関する研 究：口腔衛生学会雑誌，7（2），54-59，(1957).

39. 真泉平治：歯刷子の損耗度に関する研究 (会): 腔衛生学雑誌, 6 (4),213, (1957).

40. 小幡哲夫・他; 常用歯ブラシの形状と口空との関係 : 口腔衛生学会雑誌, 13 ( 2), 32-33, (1960). 